\title{
Gravitációs lencsézés alternatív gravitációelméletekben
}

\author{
Doktori (PhD) értekezés
}

\section{Horváth Zsolt}

Témavezetô: Dr. Gergely Árpád László

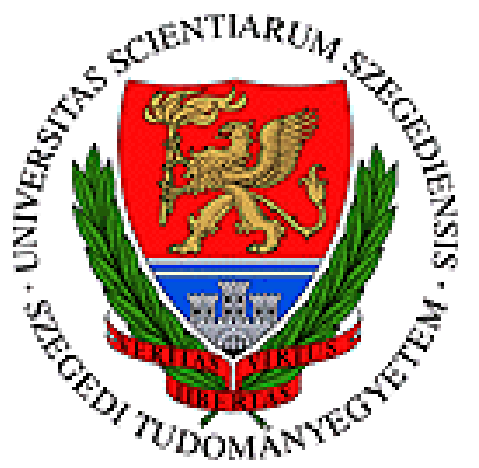

Fizika doktori iskola Szegedi Tudományegyetem Kísérleti Fizikai Tanszék Elméleti Fizikai Tanszék

SZTE TTIK

Szeged 


\section{Tartalomjegyzék}

1. Bevezetés 1

2. Gravitációs lencsézés 3

2.1. Fényelhajlási szög . . . . . . . . . . . . . . . . . . . . 3

2.2. Lencseegyenletek . . . . . . . . . . . . . . . . . . 5 5

2.3. Képek keletkezése . . . . . . . . . . . . . . . . . . . . . 8

2.4. Képek nagyítása . . . . . . . . . . . . . . . . . . . . . . . 10

2.5. Időkésés . . . . . . . . . . . . . . . . . . . . . . . . 12

2.6. Képek alakváltozása . . . . . . . . . . . . . . . . . . . . 16

2.7. Tengelyszimmetrikus lencsék . . . . . . . . . . . . . . . . 18

3. Gömbszimmetrikus fekete lyukak alternatív gravitációelméletekben 19

3.1. Brán világ elméletek . . . . . . . . . . . . . . . . . . . . . . . . . . 19

3.1.1. Az árapálytöltésú fekete lyuk . . . . . . . . . . . . . . . . . 20

3.2. Hořava-Lifshitz elméletek . . . . . . . . . . . . . . . . 21

3.2.1. A Kehagias-Sfetsos fekete lyuk . . . . . . . . . . . . . . . 22

3.3. $\mathrm{f}(\mathrm{R})$ elméletek . . . . . . . . . . . . . . . . . . . 23

3.3.1. Gömbszimmetrikus kompakt égitest az $f(R)=R^{n}$ elméletben . . . 23

3.3.2. Energiafeltételek a kis energiájú, távoli tér tartományban . . . . . . . . 25

4. Az árapálytöltésú fekete lyuk gravitációs lencsézése 29

4.1. Gyenge gravitációs lencsézés árapálytöltésû fekete lyuk jelenlétében . . . . . . 29

4.1.1. A lencseegyenlet . . . . . . . . . . . . . . . . . 30

4.1.2. A tömeg és árapálytöltés paraméterben másodrendú lencseegyenlet . . 31

4.1.3. Tömeg dominált gyenge lencsézés $\mathcal{O}\left(\bar{\varepsilon}^{2}\right)$ rendig . . . . . . . . . . . 33

4.1.4. Árapálytöltés dominált gyenge lencsézés $\mathcal{O}(\bar{\eta})$ rendig . . . . . . . . . . 34

4.1.5. Árapálytöltés dominált gyenge lencsézés $\mathcal{O}\left(\bar{\eta}^{2}\right)$ rendig . . . . . . . . . 40

4.1.6. A (4.5) lencseegyenlet és a Virbhadra-Ellis lencseegyenlet összehasonlítása . . . . . . . . . . . . . . . . . 41

4.2. Erôs gravitációs lencsézés árapálytöltésú fekete lyuk jelenlétében . . . . . . . 42

4.2.1. Null geodetikusok és relativisztikus Einstein gyưrúk gömbszimmetrikus, sztatikus téridốben . . . . . . . . . . . . . . . . . 42

4.2.2. Az elsố relativisztikus Einstein gyứrü . . . . . . . . . . . . . . . . . . 44

4.2.3. Kényszerek megállapítása az árapálytöltésre . . . . . . . . . . . . . . 44

5. A Kehagias-Sfetsos fekete lyuk gravitációs lencsézése 46

5.1. A képek helyzete a Kehagias-Sfetsos téridôben . . . . . . . . . . . . . . . . 47

5.1.1. Einstein gyuuruúk keletkezése . . . . . . . . . . . . . . . . 47

5.1.2. Képek keletkezése . . . . . . . . . . . . . . . . . . . . . 49

5.2. Kényszerek megállapítása a Hořava-Lifshitz paraméterre . . . . . . . . . . 51

5.2.1. Kényszerek gyenge lencsézésből . . . . . . . . . . . . . . . . 51 
5.2.2. Kényszerek relativisztikus lencsézésből _ . . . . . . . . . . . . 52

5.2.3. Összehasonlítás egyéb jelenségekből származó kényszerekkel . . . . . 53

6. Gyenge gravitációs lencsézés $\mathbf{R}^{n}$ gravitációelméletben $\quad 55$

6.1. Az elhajlási szög . . . . . . . . . . . . . . . . . . 55

6.2. Lencseegyenletek . . . . . . . . . . . . . . . . . . 57

6.3. Képek helyzetei és nagyításai . . . . . . . . . . . . . . . . . . . . 59

6.4. Hatványtörvény-szerú viselkedés . . . . . . . . . . . . . . . . . . . . . . 59

7. Összefoglalás $\quad 62$

7.1. Az árapálytöltésú fekete lyuk gravitációs lencsézése . . . . . . . . . . . . . . 62

7.2. A Kehagias-Sfetsos fekete lyuk gravitációs lencsézése . . . . . . . . . . . . . . 63

7.3. Gyenge gravitációs lencsézés $\mathrm{R}^{n}$ gravitációelméletben . . . . . . . . . 63 


\section{1. fejezet}

\section{Bevezetés}

Az általános relativitáselmélet (ÁRE) értelmében az energia-impulzus görbíti a téridôt és a fény pályája ennek megfelelően elhajlik. Ezt veszi figyelembe a gravitációs lencsézés, mely a gravitációs mező tulajdonságainak vizsgálatában hasznos eszköznek bizonyult. Kezdetben a megfigyeléseket az elmélet jóslatainak igazolására használták. Az utóbbi években a világegyetem nagy léptékú szerkezetének tanulmányozására alkalmazzák, feltérképezve a sötét anyag eloszlását. A galaktikus forgásgörbék és a galaxishalmazok mozgásának tanulmányozása alapján az ÁRE csak akkor egyeztethető össze a megfigyelésekkel, ha a világegyetemet egy nem világító anyag tölti ki.

Az értekezésben gravitációs lencsézést vizsgálunk három kiválasztott alternatív gravitációelméletben.

A fény terjedése a görbült téridőben megfigyelhető jelenségeket okoz. Ezek mérhetôk a jelenlegi távcsövekkel. A legfontosabb a többszörös képek keletkezése és azok szögtávolságai. A lencsézés a képek fényességeiben változást okoz. Ha a forrás vagy a lencse időfüggést mutat, a fényjelek érkezési idejében történő változások mérhetők. A kiterjedt források képének alakja és orientációja eltér a forrásétól.

A 2. fejezetben áttekintjük a gravitációs lencsézés alapjait. A 2.1 alfejezetben tetszőleges tömegeloszlású vékony lencsék fényelhajlító hatását tárgyaljuk. A pontszerú lencsére érvényes fényelhajlási szög szolgál kiindulópontként. A 2.2 alfejezetben a lencsézés geometriája alapján levezetjük a legegyszerúbb, kisszögú lencseegyenletet. Definiáljuk a Fermat potenciált, amellyel a lencseegyenlet differenciálegyenlet alakban írható. Az egyenlet a lencsézésre vonatkozó Fermat elvet fejezi ki. Ha a lencse pontszerú, akkor a lencsézés geometriája tengelyszimmetrikussá válik. A pontszerú lencsére érvényes lencseegyenletek két családba tartoznak. Ezek abban különböznek, hogy a fény bejövő és kimenő szakasza között milyen kapcsolat áll fenn. A 2.3 alfejezet a képek keletkezését tárgyalja, ezen belül a többszörös képek létrejöttének feltételeit. Bevezetjük a képek osztályozását a Fermat potenciál deriválttenzora segítségével. A 2.4 alfejezetben értelmezzük a képek nagyítását ill. fényerôsítését. Ehhez kapcsolódik a képek paritás szerinti osztályozása. A negatív paritású képek az alakváltozás mellett tükrözve is vannak. Ha a lencse egy forrás több képét hozza létre, akkor általában a fény utazási ideje a különböző fényutak mentén különböző. A 2.5 alfejezetben az időkésés mértékét számoljuk ki, hullámoptika alkalmazásával. A képek alakváltozását a 2.6 alfejezetben elemezzük. Adott fényesség eloszlású kiterjedt forrás látszólagos alaktorzulását adott fényesség értékekhez tartozó izofóta görbék alakváltozásaival értelmezzük. Mivel a galaxisok izofótái nem pontosan elliptikusak, ezért alakjuk jellemzésére integrálközép jellegú mennyiségeket vezetünk be. A képek alakja három hatás eredménye, melyek a Fermat potenciál deriválttenzorától függnek. Ezek a nyúlás (ill. zsugorodás), a nyírás és az elfordulás. A galaxisok képének alakja a saját ellipticitás és a nyírás közremúködésével jön létre. A 2.7 alfejezetben ismertetjük a legegyszerúbb lencse modelleket. Ezek sûrúsége tengelyszimmetrikus és a galaxisok modellezésére alkalmasak. 
A szimmetria következtében a lencseegyenlet egydimenzióssá válik. A tengelyszimmetrikus lencsék határesete a pontszerú lencse.

A gravitációs lencsézés alkalmazható annak meghatározására, hogy a különböző gravitációelméletek közül melyik a helyes. A megfigyelésekben ugyanis nem csak ismeretlen anyagfajták gravitációs hatása tükröződik, hanem megjelenik bennük a gravitációs dinamika eltérése is az ÁRE-tôl.

A 3. fejezetben azt a három alternatív gravitációelméletet mutatjuk be, amelyben a lencsézést vizsgáljuk. Az egyes elméleteket bemutató alfejezetekben ismertetjük azokat a kompakt objektumokat is, amelyeket gravitációs lencseként alkalmazunk. A 3.1 alfejezetben a brán világ elméletekkel kapcsolatos alapismereteket tárgyaljuk. A standard modellbôl ismert anyag egy 3+1 dimenziós hiperfelületre (brán) korlátozódik, és a gravitáció egy nagyobb dimenziós téridőben hat. A bránon az Einstein egyenlet helyett az ún. effektív Einstein egyenlet érvényes, melynek vannak fekete lyuk megoldásai is. Az árapálytöltésú fekete lyuk sztatikus, gömbszimmetrikus, vákuum megoldás. Két paraméter jellemzi: a tömeg és az árapálytöltés. Az árapálytöltés annak az 5 dimenziós téridônek a Weyl görbületéből származik, amelybe a brán be van ágyazva. Annak ellenére, hogy az árapálytöltés hasonló szerepet játszik mint az ÁREben a Reissner-Nordström fekete lyuk elektromos töltésének négyzete, a negatív árapálytöltésnek nincs megfelelője az ÁRE-ben. A 3.2 alfejezet a Hořava-Lifshitz elméletet mutatja be. A Hořava-Lifshitz elmélet olyan térelméletek családja, amelyekben a téridôn egy kitüntetett fóliázást választunk, ezzel sértve a Lorentz invarianciát. Ezek az elméletek gravitációelméletként értelmezhetôk. Kehagias és Sfetsos fekete lyuk megoldása aszimptotikusan sík, gömbszimmetrikus, sztatikus. A metrika a tömegtôl és az ún. Hořava-Lifshitz paramétertől függ. A 3.3 alfejezet az $f(R)$ elméletekbe ad bevezetést, azon belül a hatványfüggvény alakú $R^{n}$ elméletbe. Ezekben az Einstein egyenlet geometriai oldalát módosítják ahelyett, hogy egzotikus energia-impulzus tenzorokkal dolgoznának. Az Einstein-Hilbert hatást kicseréljük a Ricci skalár valamilyen függvényére. Az egyenletek gömbszimmetrikus, sztatikus, vákuum megoldása egy kompakt égitestre vezet. Ennek a levezetését is ismertetjük.

A 4.-6. fejezetek és a 3.3 alfejezet új eredményeket tartalmaznak, az [1]-[4] publikációim alapján. Az [1] cikkemből származik továbbá a 2.2 ábra.

A 4. fejezetben képek keletkezését, helyzetüket és fényességüket tárgyaljuk árapálytöltésú fekete lyuk jelenlétében. Különböző pontosságú lencseegyenletek között állapítunk meg kapcsolatokat. Az 5. fejezetben a Kehagias-Sfetsos fekete lyuk által keltett képeket tanulmányozzuk, és kényszereket határozunk meg a Hořava-Lifshitz paraméterre. A relativisztikus lencsézés 15 nagyságrenddel élesebb kényszert ad, mint a gyenge. A 6. fejezetben gyenge lencsézést vizsgálunk olyan kompakt égitest jelenlétében, amelynek külsố téridôjét a 3.3.1 szakaszban vezetjük le. A képek fluxusainak aránya a képek szögtávolságának függvényében hatványtörvénynek tesz eleget. 


\section{2. fejezet}

\section{Gravitációs lencsézés}

Az ÁRE szerint a fény null geodetikusokon terjed. Gyenge tér közelítésben a geodetikusok nulladrendben egyenesek, ezért használunk egyeneseket a fénypályákra. Ez a közelítő leírás szakaszok és euklideszi trigonometria alkalmazásából áll. A két leggyakrabban előforduló háttérgeometria az euklideszi és a Friedmann-Robertson-Walker (FRW) téridő. Az euklideszi téridő főként elméleti vizsgálatokban használatos, pl. különböző lencseegyenletek (2.2 alfejezet) összehasonlítása. A FRW pedig a megfigyelések értelmezése során fordul elő. Az euklideszi téridőben érvényes legegyszerúbb, ún. kisszögú lencseegyenlet (2.2 alfejezet) formailag helyes marad a FRW világegyetemben is, amennyiben a $D_{L}, D_{L S}, D_{S}$ távolságokat a $z_{L}, z_{L S}, z_{S}$ vöröseltolódásokkal definiáljuk [5]. Ekkor a lencse- és forrás sík (2.1 ábra) helyett lencse- ill. forrás szférával dolgozunk. kis szög közelítésben, az optikai tengely közelében ezek a szférák az érintősíkjaikkal helyettesíthetők [5]. A kis szög közelítést minden 1 ívmásodpercnél nem nagyobb $\varphi$ szögre alkalmazni fogjuk, azaz $|\varphi| \approx \sin |\varphi| \approx \tan |\varphi|$. A 2.2 alfejezetben tehát a lencseegyenlet levezetéséhez az euklideszi háttér megfelelő. Az ÁRE és a csillagászat másképp értelmezi a gyenge és az erôs lencsézés fogalmát. Az értekezésben az ÁRE szóhasználatát követjük. A gyenge lencsézés során a kis szög közelítés teljesül a forrás és a képek helyzetére, továbbá az elhajlási szögre. Az erôs lencsézés során az elhajlási szög közel van $\pi$ egész számú többszöröséhez. Ez általában páros többszörös, ekkor relativisztikus lencsézésrôl beszélünk. A keletkezô képeket relativisztikus vagy magasabbrendû képeknek nevezzük. (A csillagászatban gyenge lencsézésnek azt nevezik, hogy az intergalaktikus anyag a galaxisok képének enyhe elliptikus torzulását okozza [5]. Erős lencsézés során pedig egy galaxisnak kettő vagy több képe megfigyelhetô. A megfigyelés alapján a lencse galaxis vagy galaxis halmaz tömegeloszlása modellezhető [5]. Az erős lencsézéshez sorolják még az extragalaktikus ívek keletkezését és a mikrolencsézést is.)

\subsection{Fényelhajlási szög}

A fény, ami egy $M$ tömegú gömb alakú tömeg (vagy tömegpont) mellett halad el,

$$
|\delta|=4 \frac{G}{c^{2}} \frac{M}{|\xi|}
$$

szöggel térül el, feltéve hogy a $|\xi|$ ütközési paraméter sokkal nagyobb, mint a megfelelő Schwarzschild sugár [5]

$$
R_{S}=2 \frac{G}{c^{2}} M
$$

Az ÁRE elsô tesztjei közül az egyik a Nap fényelhajlító hatását mérte egy napfogyatkozás során. A gömbszimmetrikus lencsére a newtoni gravitációból is számoltak fényelhajlási szöget. 


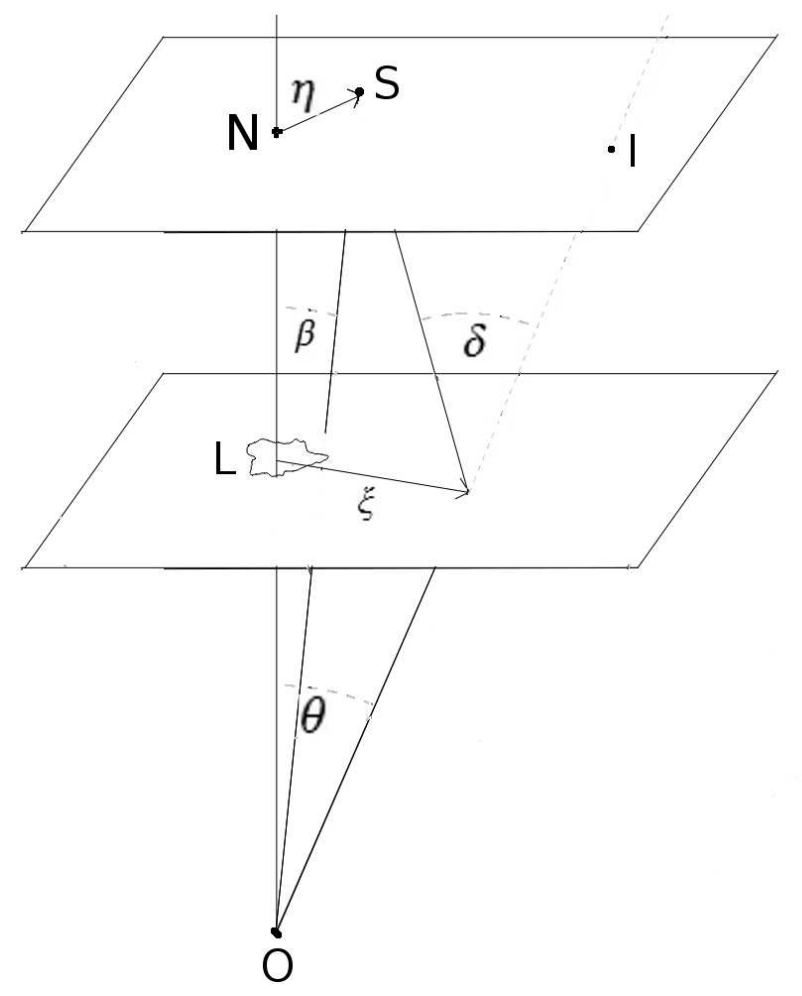

2.1. ábra. A gravitációs lencsézés geometriája euklideszi háttéren. Az S forrást tartalmazó sík az O megfigyelőtől $D_{S}$ távolságban van, az L tömegeloszlás (lencse) középpontja $D_{L}$ távolságban. Az L pontra és a megfigyelőre illeszkedő egyenes definiálja az optikai tengelyt. A forrás sík merőleges a tengelyre és tartalmazza a forrást. A tengely $\mathrm{N}$ döféspontja a forrás helyzetét jellemző koordináta rendszer origója. A lencse (vagy kép-) sík merôleges a tengelyre és tartalmazza a lencsét. L a kép helyzetét jellemzô koordináta rendszer origója. Az $\eta$ helyzetû, azaz $\beta$ valódi szögú forrásból induló fénynyaláb elhajlását a $\delta$ szögvektorral jellemezzük. A fény a lencse síkot a $\xi$ impakt vektorral adott pontban metszi, majd a tengellyel a $\theta$ látszó szöget bezárva érkezik a megfigyelőhöz. Így a megfigyelő az I képet látja. (Pontszerú lencse esetében a $\delta$ vektor irányát a $\xi$ vektorral egyirányúnak választjuk, 1. (2.2) képlet, ez a megállapodás tehát eltér a síkszögekhez tartozó vektor irányára vonatkozó szokásos megállapodástól.) 
Ez fele az ÁRE-ben kapott értéknek. Az (2.1) képlet érvényességét a Nap gravitációs terében rádió interferometriával 0.01 relatív pontossággal igazolták [6]. A 2.1 ábrán bevezetett $\delta$ vektori fényelhajlásra a

$$
\delta=4 \frac{G}{c^{2}} M \frac{\xi}{|\xi|^{2}}
$$

képlet érvényes. A lencse síkon és a forrás síkon a vektorokat komponensekre bonthatjuk, valamely (tetszés szerint orientált) derékszögú koordinátarendszerben: $\xi=\left(\xi_{1}, \xi_{2}\right), \eta=\left(\eta_{1}, \eta_{2}\right)$ ill. a szögeket $\theta=\left(\theta_{1}, \theta_{2}\right), \beta=\left(\beta_{1}, \beta_{2}\right), \delta=\left(\delta_{1}, \delta_{2}\right)$ alakban.

A fény pályáját a lencse síkban felvett $\xi_{1}, \xi_{2}$ és az ezekre merôleges $r_{3}$ koordinátákban a $\left(\xi_{1}(\lambda), \xi_{2}(\lambda), r_{3}(\lambda)\right)$ görbe írja le ( $\lambda$ a görbe paramétere). Az $r_{3}=0$ koordinátasíkot a lencsesíkra illesztjük. Bevezetjük a geometriailag vékony lencse fogalmát, ami az atomfizikából ismert Born közelítésnek felel meg: a fénysugarat a lencse közelében egyenes szakasszal közelítjük, amely merőleges a lencse síkra [5]. Így a pálya a lencse környezetében $\left(\xi_{1}, \xi_{2}, r_{3}(\lambda)\right)$ alakú, ahol $\xi_{1}, \xi_{2}$ állandók. Az asztrofizikailag jelentős lencsézési konfigurációkban teljesül a vékony lencse feltevés. Kivétel a galaxisok képének elliptikus torzulását okozó intergalaktikus világító és sötét anyag [5]. Ekkor a lencséző tömeg a forrástól a megfigyelőig terjed.

Ha $|\xi| \gg R_{S}$, akkor a fény gyenge gravitációs térben halad. Gyenge térben az Einstein egyenletek linearizálhatók. Ennek következménye, hogy tömegpontokból álló rendszer által okozott fényelhajlás szögvektora a tömegpontok (2.2) fényelhajlásainak vektori összege [5]. A tömegpontok rendszerének általánosítása a $\rho\left(\bar{r}^{\prime}\right)$ sưrúségú tömegeloszlás $\left(\bar{r}^{\prime}:=\left(\xi^{\prime}, \xi_{2}^{\prime}, r_{3}^{\prime}\right)\right)$. Ezt $d m=\rho\left(\bar{r}^{\prime}\right) d V$ tömegelemekre bontjuk. A $\bar{r}^{\prime}$ helyzetű tömegelem közelében elhaladó fény impakt vektorát a $\left(\xi_{1}-\xi_{1}^{\prime}, \xi_{1}-\xi_{2}^{\prime},-r_{3}^{\prime}\right)$ különbségvektor lencse síkba esố vetületével definiáljuk [5] (a 2.1 ábrán a $\xi$ impakt vektort a lencse síkban értelmezett 2 dimenziós vektorként vezettük be). Az $\bar{r}^{\prime}$ helyzetú $d m$ tömegelem által okozott fényelhajlás

$$
\delta=4 \frac{G}{c^{2}} d m \frac{\xi-\xi^{\prime}}{\left|\xi-\xi^{\prime}\right|^{2}},
$$

ahol tehát a $\xi=\left(\xi_{1}, \xi_{2}\right)$ és $\xi^{\prime}=\left(\xi_{1}^{\prime}, \xi_{2}^{\prime}\right)$ a lencsesíkban értelmezett síkvektorok. A különböző tömegelemektől származó eredő fényelhajlást összegzéssel ill. folytonos határesetben integrálással kapjuk:

$$
\delta(\xi)=4 \frac{G}{c^{2}} \Sigma_{i} d m_{i} \frac{\xi-\xi_{(i)}^{\prime}}{\left|\xi-\xi_{(i)}^{\prime}\right|^{2}}=4 \frac{G}{c^{2}} \iiint \rho\left(\xi_{1}^{\prime}, \xi_{2}^{\prime}, r_{3}^{\prime}\right) \frac{\xi-\xi^{\prime}}{\left|\xi-\xi^{\prime}\right|^{2}} d \xi_{1}^{\prime} d \xi_{2}^{\prime} d r_{3}^{\prime}
$$

(az integrálás $\rho$ tartójára történik) A

$$
\Sigma(\xi)=\int_{\Re} \rho\left(\xi^{\prime}, \xi_{2}^{\prime}, r_{3}^{\prime}\right) d r_{3}^{\prime}
$$

felületi tömegsúrúség bevezetésével tetszőleges tömegeloszlás által okozott fényelhajlás szöge a $\xi$ helyen "megtöró" fénysugárra

$$
\delta(\xi)=4 \frac{G}{c^{2}} \iint \Sigma\left(\xi_{1}^{\prime}, \xi_{2}^{\prime}\right) \frac{\xi-\xi^{\prime}}{\left|\xi-\xi^{\prime}\right|^{2}} d \xi_{1}^{\prime} d \xi_{2}^{\prime}
$$

(az integrálás $\Sigma$ tartójára történik)

\subsection{Lencseegyenletek}

Ha a forrásból kiinduló fénysugarak közül egy vagy több eléri a megfigyelőt, akkor ezt a tényt valamilyen lencseegyenlet fejezi ki. A lencsézés geometriája (2.1 ábra) alapján különböző pon- 
tosságú lencseegyenletek vezethetők le. Mint említettük, a legegyszerübb egyenlet tárgyalásához az euklideszi háttér megfelel. A lencse környezetében meggörbült fénysugarat két szakasszal helyettesítjük, amelyek a lencse közelében kapcsolódnak össze. A fény irányváltását az $\delta$ fényelhajlási szög jellemzi. A $\delta$ szög a lencse $\Sigma(\xi)$ tömegeloszlásától és a $\xi$ impakt vektortól függ (2.3) szerint. Az $\eta$ helyzetú forrásból induló fény a lencse síkot a $\xi$ pontban metszi, és éppen olyan mértékben térül el, hogy az $\mathrm{O}$ megfigyelố irányába halad tovább. Einstein gyúrú keletkezik, amikor a forrás, a lencse és a megfigyelő az optikai tengelyen van.

Ha az ábrán a trigonometriai függvényekre a kis szög közelítést alkalmazzuk, akkor a kisszögú lencseegyenletet kapjuk:

$$
\eta=\frac{D_{S}}{D_{L}} \xi-D_{L S} \delta(\xi)
$$

A fényelhajlást a 2.1 ábrán feltüntetett $\beta:=\arctan \left(\eta / D_{S}\right) \approx \eta / D_{S}, \theta:=\arctan \left(\xi / D_{L}\right) \approx$ $\xi / D_{L}$ szögvektorokkal is kifejezhetjük (az $\approx$ jelentése ebben az alfejezetben: kis szög közelítésben egyenlő). $\beta$-t valódi szögnek, $\theta$-t látszó(lagos) szögnek nevezzük. Bevezetjük a normált elhajlási szögvektort:

$$
\alpha:=\frac{D_{L S}}{D_{S}} \delta .
$$

Az $\alpha$ szög a (2.3) képlet alapján a következő integrálnak felel meg:

$$
\begin{aligned}
\alpha(\theta) & =\frac{1}{\pi} \iint_{\Re^{2}} \kappa\left(\theta^{\prime}\right) \frac{\theta-\theta^{\prime}}{\left|\theta-\theta^{\prime}\right|^{2}} d^{2} \theta, \\
\kappa(\theta) & :=\frac{\sum\left(D_{L} \theta\right)}{\Sigma_{k r}}, \\
\Sigma_{k r} & :=\frac{c^{2}}{4 \pi G} \frac{D_{S}}{D_{L} D_{L S}} .
\end{aligned}
$$

A $\kappa$ normált felületi tömegsûrúség definíciójában szereplő $\Sigma_{k r}$ kritikus felületi tömegsűrűség a lencseegyenletben szereplő távolságoktól függ. A kritikus jelző eredete a lencseegyenlet megoldásait tárgyaló 2.3 alfejezetből derül ki.

A $\beta, \theta, \alpha$ szögvektorokkal a lencseegyenlet a

$$
\theta-\beta-\alpha(\theta)=0
$$

alakot ölti. A lencseegyenlet tehát összekapcsolja a forrás valódi és megfigyelt helyzetét.

Említettük, hogy a (2.6) lencseegyenlet azt fejezi ki, hogy a forrásból induló fénysugarak közül néhány eléri a megfigyelőt. Az egyenlet megoldhatósága tehát azt a feltevést fogalmazza meg, hogy a fizikailag reális $\alpha(\theta)$ fényelhajlási függvények között van olyan, amelyet alkalmas $\theta$ helyen kiértékelve fennáll a (2.6) egyenlőség. Az (2.5) integrálból következik, hogy ez a $\kappa(\theta)$ normált felületi sưrúségre tett feltevés.

Megfelelő $\kappa(\theta)$ függvények családját szolgáltatja a következő észrevétel [5]. Legyen a $\kappa(\theta)$ normált felületi tömegsûrúség folytonosan differenciálható. A képsík végtelenjében, azaz a $|\theta| \rightarrow \pi / 2$ limeszben csökkenjen gyorsabban, mint $|\theta|^{-2}$ (ez asztrofizikailag reális feltevés [5]). A

$$
\begin{aligned}
& \psi(\theta):=\frac{1}{\pi} \iint_{\Re^{2}} \kappa\left(\theta^{\prime}\right) \ln \left|\theta-\theta^{\prime}\right| d^{2} \theta, \\
& \tau(\theta):=\frac{1}{2}(\theta-\beta)^{2}-\psi(\theta)
\end{aligned}
$$


mezőkkel a kisszögú lencseegyenlet differenciálegyenlet [7]:

$$
\nabla \tau=0
$$

A $\tau$ függvény az ún. Fermat potenciál [7]. Az elnevezés eredete az időkésést tárgyaló 2.5 alfejezetből derül ki. A keletkező képek látszó szögei a $\tau(\theta)$ felület szélsőértékhelyei vagy nyeregpontjai. A $\kappa(\theta)$ függvény aszimptotikus viselkedése következtében, a lencse síkon a végtelenhez közelítve a (2.8) potenciál második tagjának abszolutértéke lassabban növekszik, mint $\ln |\theta|$. Az elsô tag viszont erősebben, $|\theta|^{2}$ szerint nő, így $\tau(\theta)$ növekszik, miközben $|\theta| \rightarrow \pi / 2$. Ezért a $\tau$ függvény a folytonossága következtében egy vagy több $\theta$ helyen felveszi minimumát. Ezek a helyek képek látszó szögei, mert megoldják a (2.9) lencseegyenletet.

A [8] cikkben azt az észrevételt tették, hogy a pontszerú lencsére levezetett, szakirodalomban elterjedt lencseegyenletek alapvetôen két családba sorolhatók. Ezek abban különböznek, hogy a foton pályájának bejövő és kimenő szakasza között milyen kapcsolatot tételezünk fel.

Ha a lencse pontszerú, akkor a lencsézés geometriája tengelyszimmetrikussá válik. Abban az elfajult esetben, amikor $O, L$ és $S$ kollineáris, azaz $\beta=0$, Einstein gyürú keletkezik (akkor is a gyưrú elnevezés a szokásos, amikor a pontszerú forrás képe körvonal). Általános helyzetú $(\beta \neq 0)$ pontforrás esetén a fény pályája síkgörbe. Erre a fotonok pálya impulzusmomentumának megmaradása a magyarázat. Az $O L S$ sík ezért kitüntetett és a lencsézést a $\beta, \theta, \delta$ vektorok helyett megfelelően előjelezett szögekkel is leírhatjuk. Ezek értelmezését és az előjelkonvenciókat a 2.2 ábra szemlélteti. (Az alfejezet kedvéért nem vezetünk be új jelöléseket, azaz a $\beta$ vektornak megfelelő szöget is $\beta$-val jelöljük stb.)

$N$ a forrássík és az $O L$ optikai tengely döféspontja. Az $N$ ponttal a $D_{L S}=|\overline{L N}|$ és $D_{S}=|\overline{O N}|$ vetületek definiálhatók. A megfigyelő és a lencse távolsága $D_{L}$. Az $S$ forrás helyzetét a $\beta=\widehat{L O S}$ valódi szöggel jellemezzük. A $\beta$ szög előjelére többféle előjel konvenció használatos. Ebben a alfejezetben a forrás helyzete pozitív szög, azaz a $\beta$ vektor nagysága. Ezzel szemben a többszörös képek $(I)$ keletkezését a $\theta=\widehat{I O L}$ látszó szög előjele fejezi ki: a pozitív látszó szögek az optikai tengely "feletti", a negatív látszó szögek az optikai tengely "alatti" képekhez tartoznak. A $\delta=\widehat{S A I}$ fényelhajlási szögre azt a megállapodást követjük, hogy $\delta>0$ amikor a fény az optikai tengely felé térül el, ellenkezó esetben $\delta<0$ [11]. Egy másik előjel konvenció szerint, ami a tengelyszimmetrikus lencsék tárgyalása ( 2.7 alfejezet) során használatos, a negatív látszó szögú képekhez tartoznak a negatív elhajlási szögek. A (2.5) képlet figyelembevételével ez annak felel meg, hogy az $\alpha(\theta)$ ill. $\delta(\theta)$ függvény páratlan:

$$
\delta(-\theta)=-\delta(\theta)
$$

Az Ohanian lencseegyenlet család esetében azt tesszük fel, hogy a fény pályájának bejövő és kimenő szakaszához tartozó impakt paraméterek $\left(b=|\xi|=D_{L} \sin |\theta| \approx D_{L}|\theta|\right.$ az 5.1 ábrán) egyenlôk. A Virbhadra-Ellis család egyenleteit az jellemzi, hogy a két szakasz csatlakozási pontja a lencse síkban van.

Az Ohanian család névadó egyenlete [9], [8]

$$
\theta+\arcsin \left(\frac{D_{L}}{D_{L S}} \sin \theta \cos \widehat{S L N}\right)-\delta-\widehat{S L N}=0
$$

Ez gyakorlati célokra kevésbé alkalmas, mert nem teremt kapcsolatot a $\beta$ valódi szög és a $\theta$ látszó szög között. A Bozza-Sereno lencseegyenlet [10] ekvivalens az (2.11) egyenlettel [8], és tartalmazza a $\beta$ valódi szöget:

$$
D_{S} \tan \beta=D_{L} \sin \theta \cos (\delta-\theta)-\sqrt{\frac{D_{L S}^{2}}{\cos ^{2} \widehat{S L N}}-D_{L}^{2} \sin ^{2} \theta} \cos (\delta-\theta) .
$$


Bozza javasolta a

$$
D_{S} \tan \beta \cos (\delta-\theta)=D_{L} \sin \theta-D_{L S} \sin (\delta-\theta)
$$

lencseegyenletet [8], mellyel elkerülhető a nem megfigyelhető $\widehat{S L N}$ szög használata. Az egyenlet család legpontosabb tagját a 4.1.1 szakaszban vezetjük le $(s=\operatorname{sgn} \theta)$ :

$$
0=\frac{2 D_{L}}{D_{S}} \cos \left(\frac{\delta}{2}-|\theta|\right) \cos |\theta| \sin \frac{\delta}{2}+\cos (\delta-|\theta|)(\sin |\theta|-s \cos |\theta| \tan \beta)-\sin \delta .
$$

Az egyenletet az árapálytöltésú fekete lyuk által keltett képek meghatározására fogjuk alkalmazni.

A Virbhadra-Ellis család névadó egyenlete [11]:

$$
\tan |\theta|-\tan (s \beta)-\frac{D_{l s}}{D_{s}}[\tan |\theta|+\tan (\delta-|\theta|)]=0 .
$$

A (2.12) lencseegyenletből következik a Virbhadra-Ellis egyenlet mint egy jól definiált közelítés [1]. A (2.13) egyenletnél pontosabb a Dabrowski-Schunck egyenlet [12]:

$$
\sin (\theta-\beta)=\frac{D_{l s}}{D_{s}} \cos |\theta| \cos \left[\arcsin \left(\frac{D_{s}}{D_{l s}} \sin (|\theta|-\theta+\beta)\right)\right][\tan |\theta|+\tan (\delta-|\theta|)] .
$$

A $\beta=0$ esetben a (2.13) és a (2.14) egyenletek megegyeznek. A 2.1 ábra szerint ebbe a családba tartozik a (2.6) kisszögú egyenlet egydimenziós változata is:

$$
\theta-\beta-\frac{D_{L S}}{D_{S}} \delta(\theta)=0 .
$$

\subsection{Képek keletkezése}

Az előző alfejezetben kiderült, hogy alkalmas tömegeloszlású vékony lencse esetében a lencseegyenlet megoldható. A $\tau$ Fermat potenciálra vonatkozó érvelés azonban nem érvényes pontszerú lencsére.

Ha a lencse és a forrás pontszerú, akkor két kép keletkezése bizonyítható.

Az egyszerúség kedvéért a lencse tömegét pozitívnak választjuk. Így a lencsézést vonzó kölcsönhatás okozza, a 2.2 ábra a.) és c.) részeinek megfelelően. Tehát $\delta>0$ és a (2.1) képlet alapján

$$
\delta=4 \frac{G}{c^{2}} \frac{M}{|\xi|}=4 \frac{G}{c^{2}} \frac{M}{D_{L}|\theta|} .
$$

Az a.) konfigurációban $D_{L S} \delta \approx D_{S}|\theta|-D_{S} \beta$, ezért $\beta \approx|\theta|-D_{L S} \delta / D_{S}$ és $\beta|\theta| \approx$ $\theta^{2}-4 G M D_{L S} / c^{2} D_{S} D_{L}$. A c.) esetben $D_{L S} \delta \approx D_{S}|\theta|+D_{S} \beta$, ezért $\beta \approx-|\theta|+D_{L S} \delta / D_{S}$ és $\beta|\theta| \approx-\theta^{2}+4 G M D_{L S} / c^{2} D_{S} D_{L}$. A látszó szögre vonatkozó előjelkonvenció figyelembevételével mindkét esetben a

$$
0=\theta^{2}-\beta \theta-4 \frac{G}{c^{2}} M \frac{D_{L S}}{D_{L} D_{S}}
$$

ún. Schwarzschild lencseegyenlet érvényes. Az elnevezés arra utal, hogy az $M$ tömegú Schwarzschild fekete lyuk lencsére is érvényes, feltéve hogy $|\xi| \gg R_{S}$. A pontszerú lencse a pontszerú forrásnak két ellentett előjelú képét hozza létre:

$$
\begin{aligned}
& \theta_{ \pm}=\frac{\beta \pm \sqrt{\beta^{2}+4 \theta_{E}^{2}}}{2}, \\
& \theta_{E}^{2}:=4 \frac{G}{c^{2}} M \frac{D_{L S}}{D_{L} D_{S}} .
\end{aligned}
$$




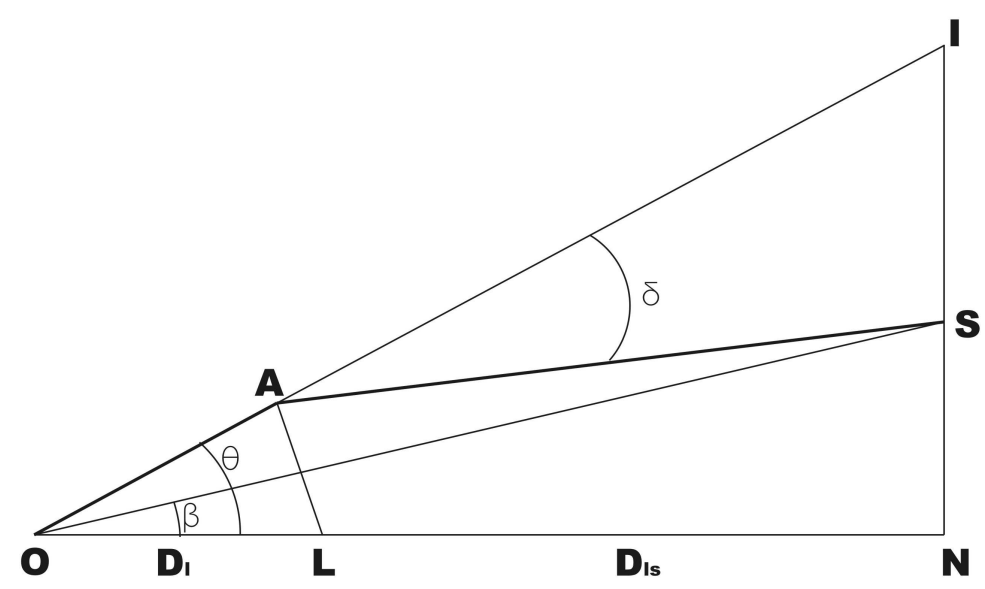

a.)

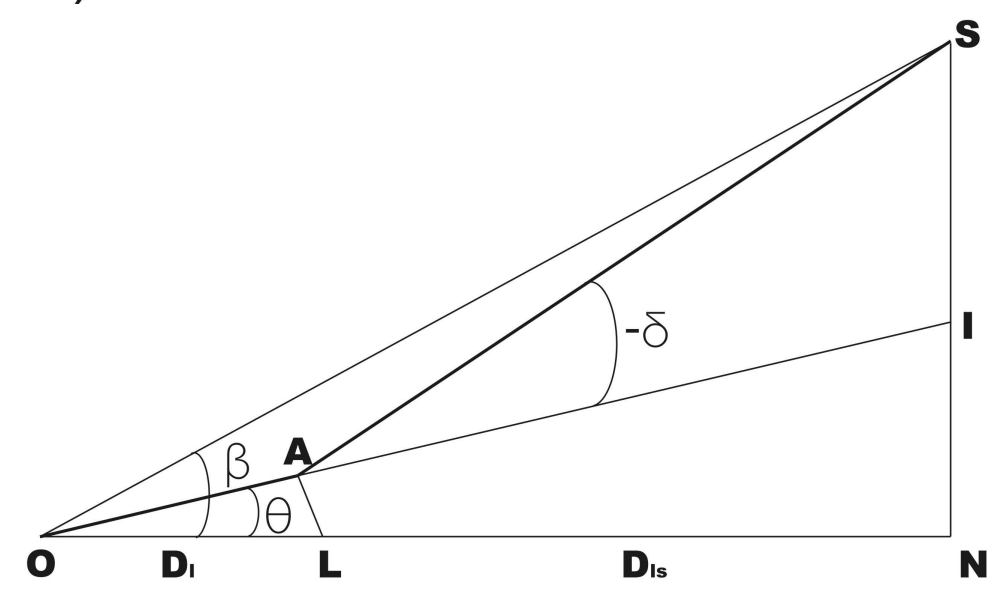

b.)

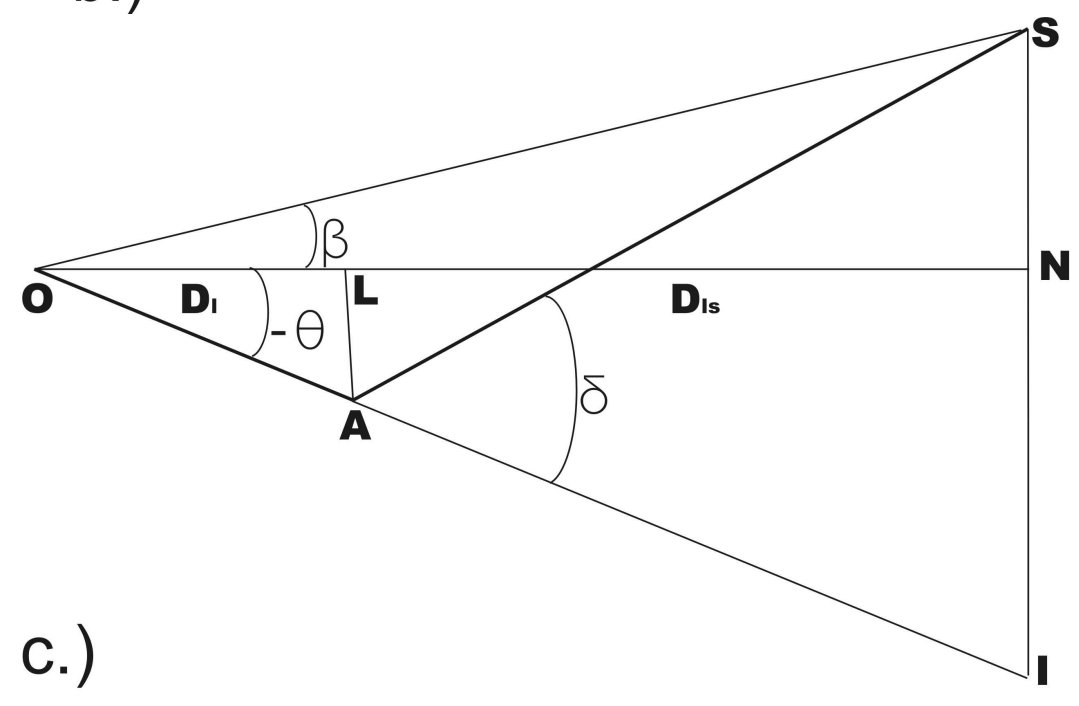

2.2. ábra. A tipikus lencsézési konfigurációk ábrázolásai [1]. Az S forrás fényt bocsát ki, amit az L lencse elhajlít, így az $\mathrm{O}$ megfigyelő az I képet látja. A $\beta$ és $\theta$ szögeket a forrás valódi és látszólagos irányai feszítik ki a lencsét és a megfigyelőt összekötő optikai tengellyel. A fény az optikai tengely felé térül el, az (a) esetben a lencse felett, a (c) esetben a lencse alatt elhaladva. A (b) eset egy taszító kölcsönhatásnak felel meg, melyre $0<\theta<\beta$ teljesül. 
A $\theta_{E}$ szög az Einstein gyưrú sugara, azaz a (2.17) egyenlet megoldásai a $\beta=0$ elfajult esetben $\pm \theta_{E}$.

Általában a lencsét nem látjuk, így a $\theta_{ \pm}$látszó szögek sem mérhetôk külön-külön. Azonban a képek szögtávolsága mérhetô mennyiség:

$$
\theta_{+}-\theta_{-}=\sqrt{\beta^{2}+4 \theta_{E}^{2}}
$$

A képlet szerint a szögtávolság a lencse tömegéről és a $D_{L}, D_{L S}$ távolságokról hordoz információt.

Legalább 3 kép keletkezésének feltételét a $\Sigma(\xi)$ tömegeloszlású lencsére a képek osztályozása segítségével lehet megfogalmazni. Ismét legyen a $\kappa(\theta)$ normált felületi tömegsúrúség folytonosan differenciálható, amely a képsík végtelenjében gyorsabban csökken mint $|\theta|^{-2}$. A képek a lencsézést jellemző

$$
A_{i j}(\theta):=\partial_{i} \partial_{j} \tau(\theta)
$$

deriválttenzor segítségével osztályozhatók [5]. (Feltesszük, hogy a $\theta$ képre det $A(\theta) \neq 0$, ekkor a képet közönségesnek nevezzük.)

I. típus: $\tau$ minimumának felel meg, ahol det $A>0$ és tr $A>0$.

II. típus: $\tau$ nyeregpontjának felel meg, ahol det $A<0$.

III. típus: $\tau$ maximumának felel meg, ahol det $A>0$ és $\operatorname{tr} A<0$.

A nyom számolása során a $\partial^{k} \partial_{k} \ln \left|\theta-\theta^{\prime}\right|$ deriváltat a $2 \pi \delta\left(\theta_{1}-\theta_{1}^{\prime}\right) \delta\left(\theta_{2}-\theta_{2}^{\prime}\right)$ disztribúcióval azonosítjuk, így $\operatorname{tr} A=2-2 \kappa$ adódik [13], [7]. Ezért I. típusú $\theta_{I}$ képre $\kappa\left(\theta_{I}\right)<1$.

Ebből az észrevételből következik, hogy ha $\Sigma(\xi)=\Sigma\left(D_{L} \theta\right)>\Sigma_{k r}$ valamely $\theta$ kép helyén, akkor legalább 3 kép keletkezik. Ez a következőképpen látható be. A $\nabla \tau$ vektormező zérushelyeit (szakszerúbben: szinguláris pont [14]) kell megszámolnunk a lencsesíkon. A $\theta$ helyen $\kappa(\theta)=\Sigma\left(D_{L} \theta\right) / \Sigma_{k r}>1$, tehát a $\theta$ kép II. vagy III. típusú. Ennek a szinguláris pontnak az ún. indexe tehát $\operatorname{sgn}\left(\operatorname{det} \partial_{i} \nabla_{j} \tau\right)=+1$ [14]. A $\kappa$ súrúség aszimptotikus viselkedésére tett feltevésünk miatt, mint már említettük, van egy minimumhelye $\tau$-nak, amely egy másik, I. típusú kép. Harmadik kép létezése Poincaré index tételének következménye: a $\nabla \tau$ vektormezőnek 1-gyel több szélsőértékhelye van, mint nyeregpontja (precízebben: vektormező szinguláris pontjai indexeinek összege a sokaság Euler karakterisztikája, ez euklideszi síknak +1 [14]).

Tehát ha a $\Sigma\left(D_{L} \theta\right)>\Sigma_{k r}$ tulajdonságú $\theta$ hely nyeregpont, akkor a képek nyeregpont + minimum + további szélsőértékhely [+ esetleg még további képek]. Ha $\theta$ maximum, akkor a képek maximum + minimum + nyeregpont [+ esetleg még további képek].

A $\kappa$ sûrúség definíciójában szereplő $\Sigma_{k r}$ kritikus felületi tömegsưrűség elnevezése tehát onnan ered, hogy elégséges feltételt szolgáltat a harmadik kép keletkezésének [5].

\subsection{Képek nagyítása}

Adott $\Sigma(\xi)$ tömegeloszlás esetén a (2.6) lencseegyenlet egy $\eta(\xi)$ ill. $\beta(\theta)$ függvényt határoz meg, ami a lencse síkból a forrás síkra képez. (Általában a $\beta(\theta)$ függvénynek nincs inverze, ezért a lencseegyenlet nem határoz meg egyértékú $\theta(\beta)$ függvényt.) A $\beta(\theta)$ függvény Jacobi mátrixa éppen $A_{i j}$ :

$$
A_{i j}\left(\theta_{1}, \theta_{2}\right)=\frac{\partial\left(\beta_{1}, \beta_{2}\right)}{\partial\left(\theta_{1}, \theta_{2}\right)}\left(\theta_{1}, \theta_{2}\right)=\frac{\partial^{2} \tau}{\partial \theta_{i} \partial \theta_{j}}\left(\theta_{1}, \theta_{2}\right)
$$

A forrás és a kép felületét felbonthatjuk felületelemekre, 2.3 ábra. Ha $\theta_{0}$ (ill. $\xi_{0}$ ) egy pont a $d A_{I}$ infinitezimális felületelemben, akkor a $d A_{I} \rightarrow d A_{S}$ leképezés lineáris közelítése $(I$ a 2 rendú 


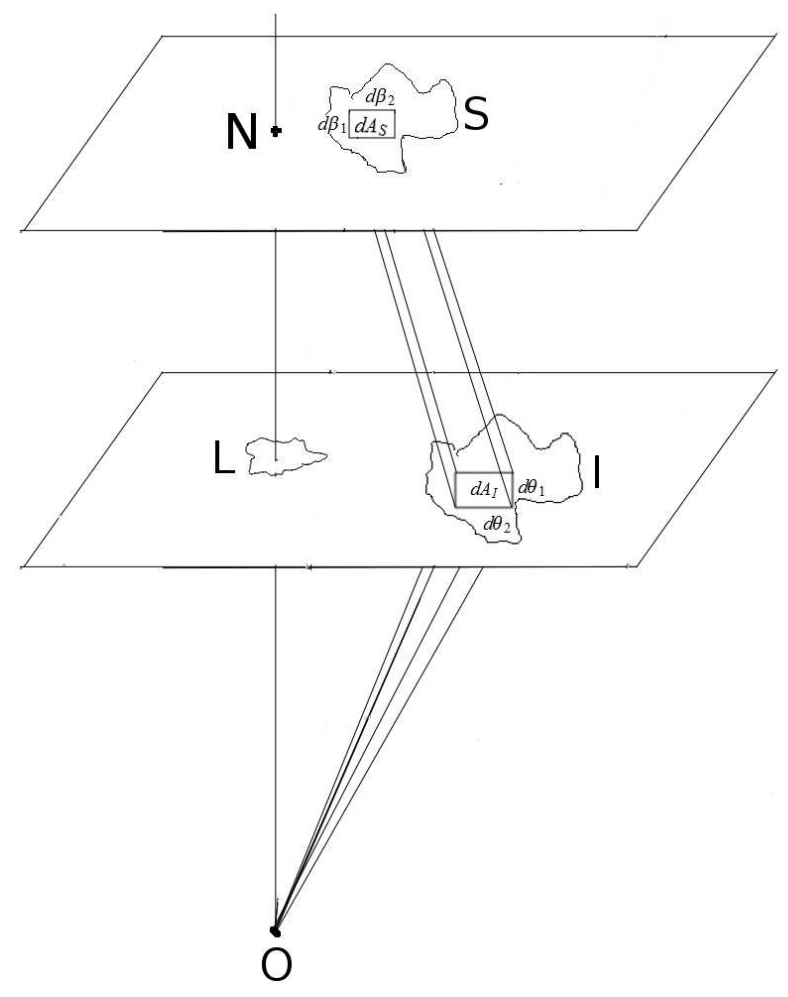

2.3. ábra. A forrás egy eleme térszögének látszólagos megváltozása. A $d A_{S}$ felület $d A_{S} / D_{S}^{2}$ térszögben látszana az $\mathrm{O}$ pontból, ha a lencse nem létezne. A lencsézés következtében a $d A_{I}$ kép keletkezik, melynek térszöge $d A_{I} / D_{L}^{2}$.

egységmátrix)

$$
\begin{aligned}
& \beta\left(\theta_{1}, \theta_{2}\right) \approx \beta\left(\theta_{0,1}, \theta_{0,2}\right)+A\left(\theta_{0,1}, \theta_{0,2}\right) \cdot\left(\begin{array}{l}
\theta_{1}-\theta_{0,1} \\
\theta_{2}-\theta_{0,1}
\end{array}\right) . \\
& \eta\left(\xi_{1}, \xi_{2}\right) \approx \eta\left(\xi_{0,1}, \xi_{0,2}\right)+D_{S} I \circ A \circ \frac{1}{D_{L}} I\left(\xi_{0,1}, \xi_{0,2}\right) \cdot\left(\begin{array}{l}
\xi_{1}-\xi_{0,1} \\
\xi_{2}-\xi_{0,2}
\end{array}\right) .
\end{aligned}
$$

A $d A_{S} / d A_{I}$ terület arányt az $\eta\left(\xi_{1}, \xi_{2}\right)$ transzformáció lineáris közelítésének determinánsa adja meg. Az $A$ transzformáció determinánsa pedig a $d A_{S}$ és $d A_{I}$ felületelemekhez tartozó $d \omega_{S}$ és $d \omega_{I}$ térszögek aránya:

$$
\frac{d \omega_{S}}{d \omega_{I}}=\frac{d A_{S} / D_{S}^{2}}{d A_{I} / D_{L}^{2}}=\operatorname{det} A
$$

Ha $\operatorname{det} A$ nem 0 akkor a reciprokát a $d A_{I}$ képelemhez tartozó nagyításnak nevezzük [5]:

$$
\mu(\theta):=\frac{1}{\operatorname{det} A(\theta)} .
$$

$\mu(\theta)$ nem lehet nulla és előjelétől függóen a $\theta$ helyet pozitív vagy negatív paritásúnak nevezzük. Értelemszerúen, ha egy kiterjedt forrás minden pontjának képe pozitív/negatív paritású, akkor a teljes képet szintén pozitív/negatív paritásúnak nevezzük. A pozitív paritású képek alakja a forrás alakjától eltér, a negatív paritású képek az alakváltozás mellett tükrözve is vannak. (A pontszerú lencse esetében, a képek látszó szögére bevezetett előjel megállapodásunk éppen olyan, hogy az egyúttal a paritást is megadja.) Az alakváltozás jellegzetességeit az $A$ mátrix határozza meg, 1. 2.6 alfejezet. 
zük:

Kierjedt forrás képének nagyítását a képelemek nagyításainak súlyozott átlagával értelmez-

$$
\begin{aligned}
\mu: & =\frac{\iint_{\text {orrás }} I(\beta) \mu(\beta) d^{2} \beta}{\iint_{\text {forrás }} I(\beta) d^{2} \beta}, \\
\mu(\beta): & =\sum_{i}\left|\mu\left(\theta_{i}\right)\right| .
\end{aligned}
$$

Az integrálást lényegében az $I(\beta)$ felületi fényesség profil tartójára végezzük, az $i$ index pedig a $\beta$ helyen lévő forráselem képein fut végig. A $\beta$ helyzetû $d A_{S}$ infinitezimális forrás fluxusának az $I(\beta) d \omega_{S}$ szorzatot nevezzük, hasonlóan a megfelelő $\theta$ helyzetú $d A_{I}$ kép fluxusa $I(\beta(\theta)) d \omega_{I}[5]$. A lencsézés fényerősítő hatását a

$$
\frac{I(\beta(\theta)) d \omega_{I}}{I(\beta) d \omega_{S}}=\frac{d \omega_{I}}{d \omega_{S}}=\mu(\theta)
$$

arány jellemzi. A kép nagyítása (magnification) ill. erôsítése (amplification) tehát fogalmilag különböző, de értékben megegyezô mennyiségek. A képek nagyítása nem megfigyelhetô mennyiség, mert a források saját fluxusa ismeretlen. Ha egy forrásnak több képe van, akkor azok fluxusai aránya a megfelelő nagyítások aránya. Ezért a képek fluxusainak aránya megfigyelhetô mennyiség.

Megjegyezzük, hogy a $\mu(\beta)$ nagyítás és az $I(\beta)$ fényesség eloszlás adott frekvenciára értendő, tehát ezeknek a mennyiségeknek lehet színfüggésük. A színfüggés csak az $I(\beta)$ függvény esetében jelentôs. Ennél nagyságrendekkel gyengébb a $\mu(\beta)$ nagyításé, mely abból származik, hogy a lencse potenciálgödrében a fotonok kékeltolódást szenvednek, majd a megfigyelő felé továbbhaladva vöröseltolódást. Az így létrejövő eredő frekvenciaeltolódás mérhetetlenül kicsi, a megfigyelésekre nincs hatással. Ezért az (2.23) arány számlálójában és nevezőjében ugyanaz a $I(\beta(\theta))=I(\theta)$ fényesség szerepel [5].

Gyakorlati szempontból tehát a lencsézés színfüggetlen jelenség [5], ami az általa okozott fénygörbék jellegzetes tulajdonsága.

\subsection{Idôkésés}

Ha a lencse egy forrás több képét hozza létre, akkor általában a fény utazási ideje a különböző fényutak mentén különböző. A fénysugaraknak a megfigyelőhöz érkezéshez szükséges idejei eltérését időkésésnek nevezzük. Ha a forrás fényessége időben változik, akkor a fluxusváltozásokat a különböző képekben különböző időpontokban figyeljük meg. Az időkésés meghatározásához a képek fényváltozásait kell mérni.

A fény utazási idejéhez két hatás közremúködése járul hozzá [15]. A geometriai idôkésés abból ered, hogy az elhajlás meggörbíti a fénysugarat, amely hosszabb lesz, mintha a fény egyenes vonalban terjedne. A potenciálos időkésés azért lép fel, mert a fény áthalad a lencse gravitációs terén. Utóbbi effektust a Naprendszerben radarjelekkel igazolták [16]. Az időkésésre képletet levezetni a hullámoptika alkalmazásával a legegyszerúbb [17]. A 2.4 ábrán egy pontforrás egy rövid idejú fényvillanást bocsát ki. Az azonos utazási idejű pontok hullámfrontokat alkotnak. A fénysugarak a hullámfrontok normálisai. A forrás közelében, azaz a lencsétôl távol a hullámfrontok gömbök. Amint a hullámfrontok behatolnak a lencse gravitációs terébe, eltorzulnak. A gravitációs tér tehát úgy viselkedik mint egy fénytörő közeg.

Amikor egy hullámfront áthalad a megfigyelőn, az egy képet lát a megfelelő fénysugár irányában. A lencse közelében a hullámfrontok önmagukat metszőkké válhatnak. A többszörös 


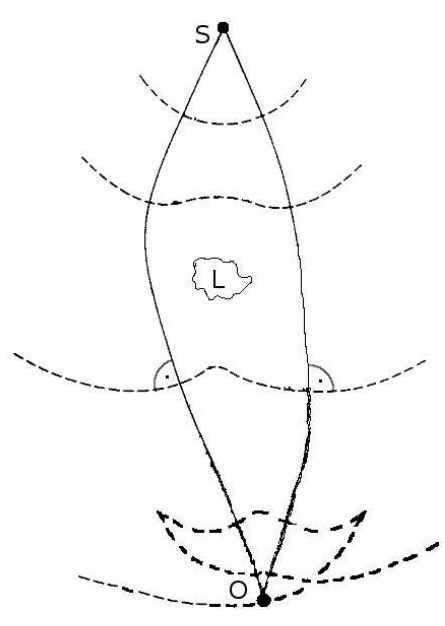

2.4. ábra. A fénysugarak a hullámfrontok normálisai. Amint a hullámfrontok behatolnak a lencse gravitációs terébe, eltorzulnak. A lencse közelében a hullámfrontok önmagukat metszőkké válhatnak. Ha a megfigyelő egy összefonódott hullámfronttal találkozik, akkor a felület egymás után többször halad át rajta. A megfelelő fénysugarak különböző irányúak, ezért a megfigyelő több képet észlel.

képeket ezek az összefonódott hullámfrontok okozzák. Ha a megfigyelő egy összefonódott hullámfronttal találkozik, akkor a felület egymás után többször halad át rajta. A megfelelő fénysugarak, azaz a felület normálisai különböző irányúak, ezért a megfigyelő több képet észlel. Az idôkésés egy kép pár két tagja között az az idő, ami a megfigyelőnek a hullámfronttal való találkozásai között telik el. Az időkésés képletének levezetését a lencseegyenlet általánosításával kezdjük. A 2.5 ábrán az $O L$ optikai tengely mellett az $O^{\prime} L$ referencia vonalat is bevezetjük, ennek a döféspontja a forrássíkon egy új vonatkoztatási pontot jelöl ki $\left(N^{\prime}\right) . O^{\prime}$ pedig a vonatkoztatási pont a megfigyelő síkon. Ennek megválasztása tetszőleges, feltéve, hogy a két tengely által bezárt $\phi$ szögre érvényes a kis szög közelítés. Az $O^{\prime} L N^{\prime}$ tengelyhez képest a megfigyelő helyzetét a $\zeta^{\prime}$, a forrásét az $\eta^{\prime}$ vektor jellemzi. A vesszőtlen $\eta, \xi, \delta$ vektorokkal a (2.4) lencseegyenlet érvényes. Az 2.5 ábra szerint $\eta^{\prime}$ és $\zeta^{\prime}$ között a kapcsolat

$$
\phi=\frac{\eta-\eta^{\prime}}{D_{L S}}=\frac{\zeta^{\prime}}{D_{L}} .
$$

$\eta$ kifejezhető ebből, ezért a (2.4) lencseegyenlet alapján

$$
\eta^{\prime}+\frac{D_{L S}}{D_{L}} \zeta^{\prime}=\frac{D_{S}}{D_{L}} \xi-D_{L S} \delta(\xi)
$$

adódik. Az egyenlet formálisan a (2.6) lencseegyenlettel azonos alakra hozható, ha bevezetjük a

$$
\beta_{\zeta^{\prime}}:=\frac{1}{D_{S}}\left(\eta^{\prime}+\frac{D_{L S}}{D_{L}} \zeta^{\prime}\right)
$$

megfigyelő helyzetétől függő forrás szöget. Ezzel a jelöléssel tehát

$$
\beta_{\zeta^{\prime}}=\theta-\frac{D_{L S}}{D_{S}} \delta(\theta)
$$

A továbbiakban egy speciális választással élünk, a referencia tengelyt a forrásra illesztjük. Ekkor $S=N^{\prime}, L$ és $O^{\prime}$ kollineáris és $\eta^{\prime}=0$. A 2.6 ábrán az $O$ megfigyelő egy pontforrásból kiinduló hullámfront összefonódott részének két rétege között helyezkedik el, azaz az egyik kép észlelése már megtörtént, a másiké pedig meg fog. A hullámfront két áthaladása között 


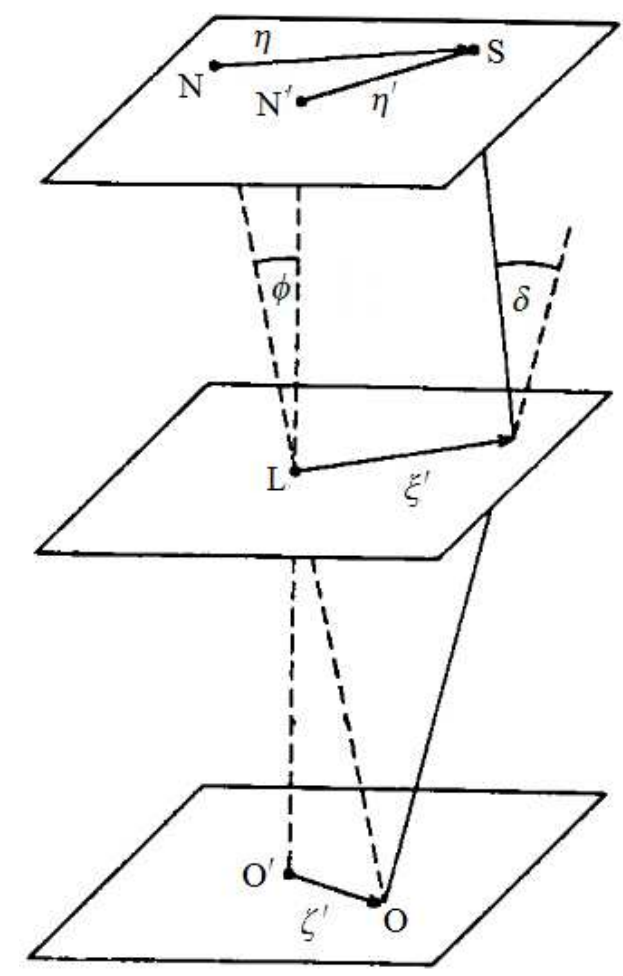

2.5. ábra. A gravitációs lencsézés geometriája. Az $O L N$ optikai tengely mellett az $O^{\prime} L N^{\prime}$ referencia vonalat is bevezetjük. $O^{\prime}$ az új vonatkoztatási pont a megfigyelő síkon. Az $O^{\prime} L N^{\prime}$ tengelyhez képest a megfigyelő helyzetét a $\zeta^{\prime}$, a forrásét az $\eta^{\prime}$ vektor jellemzi.

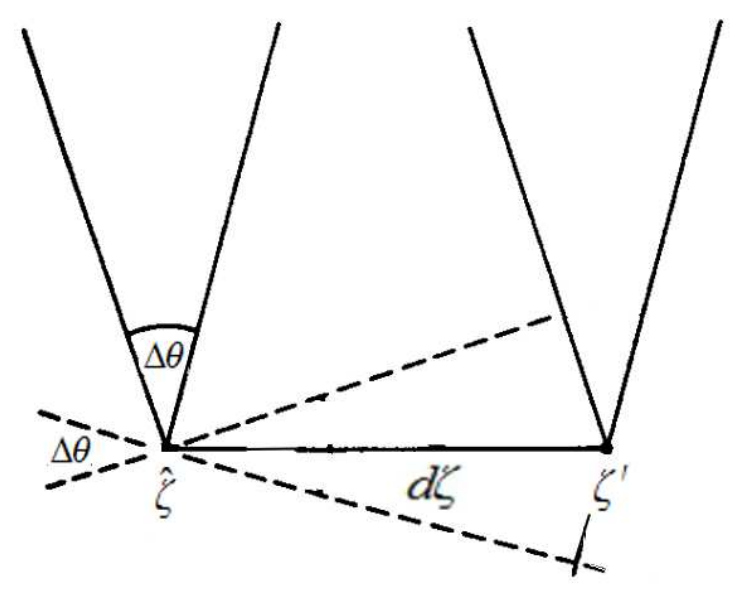

2.6. ábra. Fénysugarak (folytonos vonal) és hullámfrontok (szaggatott vonal), amelyek egy forrás két képét hozzák létre. A képek szögtávolsága $\Delta \theta=\theta_{(2)}-\theta_{(1)}$. Az önmagát metsző hullámfront metszéspontja a megfigyelố síkot a $\zeta^{\prime}$ megfigyelőhöz közeli $\hat{\zeta}$ pontban éri el. A megfigyelő a hullámfront két rétegét két különböző időpontban látja. Az észlelések között eltelt idő az időkésés. 
eltelt idő a keresett $d t$ idôkésés. Először tegyük fel, hogy a hullámfront önmetszésének helye a megfigyelő síkot a $d \zeta$ infinitezimális szakasz $\hat{\zeta}$ végpontjában éri el. A két kép $\Delta \theta=\theta_{(2)}-\theta_{(1)}$ szögtávolságával felírva az idôkésés $d t=\left(\theta_{(2)}-\theta_{(1)}\right) d \zeta / c$. Általános esetben a hullámfront önmetszésének $\hat{\zeta}$ helye a megfigyelő síkot a megfigyelőtől távolabb, nem infinitezimális távolságban éri el. Ekkor az idôkésést a $\zeta^{\prime}$ megfigyelőt és a $\hat{\zeta}$ pontot összekötő görbe mentén történô integrálással számoljuk ki [17]:

$$
\Delta t=\frac{1}{c} \int_{\zeta^{\prime}}^{\hat{\zeta}} \Delta \theta(\zeta) d \zeta
$$

A $\Delta \theta(\zeta)$ függést úgy értelmezzük, hogy a vizsgált képpár helyzetét jellemző látszó szögek folytonosan változnak a (2.26) lencseegyenlet szerint, miközben az $\zeta^{\prime}$ és $\hat{\zeta}$ pontot összekötő görbe mentén egy "virtuális megfigyelőt" mozgatunk. Mivel választásunk szerint $\eta^{\prime}=0$, a (2.25) definíció alapján $\beta_{\zeta^{\prime}}=D_{L S} \zeta^{\prime} / D_{L} D_{S}$. A $\beta_{\zeta^{\prime}}$ és $\zeta^{\prime}$ vektorok tehát párhuzamosak. Az integrálásban áttérünk a $\beta_{\zeta^{\prime}}$ változóra (amit a rövidség kedvéért a továbbiakban $\beta$-val fogunk jelölni):

$$
\begin{gathered}
\Delta t=\frac{1}{c} \frac{D_{L} D_{S}}{D_{L S}} \int_{\beta^{\prime}}^{\hat{\beta}} \Delta \theta\left(\frac{D_{L} D_{S}}{D_{L S}} \beta\right) d \beta, \\
\beta^{\prime}:=\frac{D_{L S}}{D_{L} D_{S}} \zeta^{\prime}, \quad \hat{\beta}:=\frac{D_{L S}}{D_{L} D_{S}} \hat{\zeta} .
\end{gathered}
$$

Az integrandus az a függvény ami a $\theta_{(1)}, \theta_{(2)}$ képek szögtávolságát állítja elő $\beta$ (azaz $\beta_{\zeta^{\prime}}$ ) függvényében, a (2.26) lencseegyenlet szerint. Ezért

$$
\Delta t=\frac{1}{c} \frac{D_{L} D_{S}}{D_{L S}} \int_{\beta^{\prime}}^{\hat{\beta}}\left[\theta_{(2)}(\beta)-\theta_{(1)}(\beta)\right] d \beta .
$$

Az integrandus teljes differenciálként írható. Ez úgy látható be, hogy a (2.26) lencseegyenlethez a $\tau$ Fermat potenciálnak a $\beta_{\zeta^{\prime}}$ megfigyelő helyzetétől függő forrás szöggel értelmezett változatát rendeljük hozzá.

$$
\tau^{\prime}:=\frac{1}{2}\left(\theta-\beta_{\zeta^{\prime}}\right)^{2}-\psi
$$

tehát olyan skalármező amelyre $\nabla \tau^{\prime}=0$ ekvivalens a (2.26) általánosított lencseegyenlettel.

Mivel az elhajlási potenciál $d \psi$ differenciáljára a lencseegyenlet folytán

$$
d \psi=\frac{\partial \psi}{\partial \theta_{1}} d \theta_{1}+\frac{\partial \psi}{\partial \theta_{2}} d \theta_{2}=(\nabla \psi) d \theta=(\theta-\beta) d \theta
$$

érvényes (a $\psi$ elhajlási potenciálnak is a $\beta_{\zeta^{\prime}}$ megfigyelő helyzetétôl függő forrás szöggel értelmezett változatát tekintjük), ezét mindkét $\theta_{(1)}, \theta_{(2)}$ képre

$$
\begin{aligned}
d \tau^{\prime}\left(\theta_{(i)}\right) & =\left(\theta_{(i)}-\beta\right)\left(d \theta_{(i)}-d \beta\right)-d \psi\left(\theta_{(i)}\right)=\left(\theta_{(i)}-\beta\right)\left(d \theta_{(i)}-d \beta\right)-\left(\theta_{(i)}-\beta\right) d \theta_{(i)} \\
& =-\left(\theta_{(i)}-\beta\right) d \beta=-\theta_{(i)} d \beta+d\left(\frac{1}{2} \beta^{2}\right) \\
\theta_{(i)} d \beta & =d\left(\frac{1}{2} \beta^{2}-\tau^{\prime}\left(\theta_{(i)}\right)\right) \quad i=1,2
\end{aligned}
$$

áll fenn. Következésképpen az időkésés

$$
\begin{aligned}
\Delta t & =\frac{1}{c} \frac{D_{L} D_{S}}{D_{L S}} \int_{-\tau^{\prime}\left(\theta_{(2)}\right)+\tau^{\prime}\left(\theta_{(1)}\right)}^{-\hat{\tau}\left(\theta_{(2)}\right)+\hat{\tau}\left(\theta_{(1)}\right)} d\left(-\tau^{\prime}\left(\theta_{(2)}\right)+\tau^{\prime}\left(\theta_{(1)}\right)\right) \\
& =\frac{1}{c} \frac{D_{L} D_{S}}{D_{L S}}\left[-\hat{\tau}\left(\theta_{(2)}\right)+\hat{\tau}\left(\theta_{(1)}\right)+\tau^{\prime}\left(\theta_{(2)}\right)-\tau^{\prime}\left(\theta_{(1)}\right)\right] \\
\hat{\tau} & :=\frac{1}{2}\left(\theta-\beta_{\hat{\zeta}}\right)^{2}-\psi .
\end{aligned}
$$


Megjegyezzük, hogy a fenti levezetést a FRW téridőben megismételve a

$$
\Delta t=\frac{1+z_{L}}{c} \frac{D_{L} D_{S}}{D_{L S}}\left[-\hat{\tau}\left(\theta_{(2)}\right)+\hat{\tau}\left(\theta_{(1)}\right)+\tau^{\prime}\left(\theta_{(2)}\right)-\tau^{\prime}\left(\theta_{(1)}\right)\right]
$$

eredmény adódik, ahol $z_{L}$ a lencse vöröseltolódása. A $\Delta t$ időtartam tehát a $\theta-\beta$ különbséget és a $\psi$ potenciált tartalmazó tagokból áll. A [7] cikkben megmutatták, hogy ezek a geometriai ill. potenciálos időkésésért felelősek. Továbbá a

$$
\frac{1+z_{L}}{c} \frac{D_{L} D_{S}}{D_{L S}} \tau(\theta)
$$

függvény (konstanstól eltekintve) a $D_{L} \theta$ impakt paraméterú fénysugár utazási ideje a forrástól a megfigyelőig. A Fermat potenciál elnevezés tehát onnan ered, hogy a lencseegyenlet $\nabla \tau=0$ alakja a gravitációs lencsézésre vonatkozó Fermat elvet fejezi ki.

\subsection{Képek alakváltozása}

A 2.3 alfejezetben a képek osztályozása során bevezettuik a (2.20) deriválttenzort. Említettuik, hogy a tr $A$ nyom értéke $2-2 \kappa$. Ezért az $A$ mátrix felírható $(1-\kappa) g_{i j}$ alakban, ahol a $g_{i j}$ mátrix nyoma 2 . A $g_{i j}$ mátrix nyommentes része $g_{i j}-\delta_{i j}$, melyet

$$
\left(\begin{array}{cc}
-g_{1} & -g_{2} \\
-g_{2} & g_{1}
\end{array}\right)
$$

alakban vesszük fel, azaz $g_{1}:=1-g_{11}=g_{22}-1, g_{2}:=-g_{12}=-g_{21}$. Az $(1-\kappa)\left(g_{i j}-\delta_{i j}\right)$ mátrix tehát az $A_{i j}$ mátrix nyommentes része, melyet nyírásnak nevezünk [5]. A $\kappa, g_{1}, g_{2}$ mennyiségek a képsíkon értelmezett függvények. Az optikai leképezés Jacobi mátrixa ezekkel a változókkal

$$
A(\theta):=(1-\kappa)\left(\begin{array}{cc}
1-g_{1} & -g_{2} \\
-g_{2} & 1+g_{1}
\end{array}\right)
$$

alakban írható. A képek alakja három hatás eredménye [5]. A kép izotróp nyúlásáért vagy zsugorodásáért a $1-\kappa$ tényező felelős. Az alakváltozást és elfordulást a $g_{1}, g_{2}$ ún. redukált nyírás komponensek határozzák meg. A $g=g_{1}+i g_{2}$ komplex mennyiséget a kép redukált nyírásának nevezzük.

Említettuik, hogy az (2.23) arány számlálójában és nevezőjében ugyanaz a $I(\beta(\theta))=I(\theta)$ fényesség szerepel (tetszőleges hullámhosszon). Ha a kép síkon adott $I_{0}$ fényességú $\theta$ pontok egy $\theta_{0}$ középpontú ellipszist alkotnak, akkor a (2.21) lineáris közelítésben

$$
I_{0}\left[\beta\left(\theta_{0}\right)+A\left(\theta_{0}\right)\left(\theta-\theta_{0}\right)\right]=I_{0}(\theta) .
$$

A szögletes zárójelben található lineáris függvény a kép síkon lévő ellipszist a forrássíkon egy ugyanolyan $I_{0}$ fényességú, $\beta\left(\theta_{0}\right)$ középpontú ellipszisbe képezi. Egy kör alakú, 1 sugarú forrás pozitív paritású képének tengelyei $1 /(1-\kappa)(1 \pm|g|)$. Az egységkör negatív paritású (tükrözve torzuló) képe olyan ellipszis, amelynek tengelyei $1 /(1-\kappa)(|g| \pm 1)$. Az ellipszis állását a $g=|g| e^{2 i \phi}$ redukált nyírás $\phi$ fázisa határozza meg.

A nyírás mátrixnak két független komponense van, amelyeket a $\gamma=(1-\kappa) g=\gamma_{1}+i \gamma_{2}$ komplex mennyiségben szokás összefoglalni. A $\kappa$ és $\gamma$ mennyiségekkel a nagyítás is felírható. Az A mátrix

$$
A(\theta)=\left(\begin{array}{cc}
1-\gamma_{1}-\kappa & -\gamma_{2} \\
-\gamma_{2} & 1+\gamma_{1}-\kappa
\end{array}\right)
$$


alakjából egy infinitezimális forrás képének nagyítására

$$
\mu=\frac{1}{\operatorname{det} A}=\frac{1}{(1-\kappa)^{2}-|\gamma|^{2}}
$$

adódik. Következésképpen a 2.3 alfejezetben bevezetett kép típusokra az alábbi egyenlőtlenségek érvényesek:

I. típus: $\tau$ minimuma, det $A>0,|\gamma|<1-\kappa \leq 1,|g|<1, \mu \geq 1 /\left(1-|\gamma|^{2}\right) \geq 1$.

II. típus: $\tau$ nyeregpontja, det $A<0,|\gamma|>|1-\kappa|,|g|>1$.

III. típus: $\tau$ maximuma, det $A>0,|\gamma|<|1-\kappa|,|g|<1, \kappa>1$.

Tehát a pozitív paritású képekre $|g|<1$, a negatív paritásúakra $|g|>1$. Kör alakú forrás ellipszis alakú képének tengelyaránya a $|g|<1$ esetben $(1-|g|) /(1+|g|)$, a $|g|>1$ esetben $(|g|-1) /(|g|+1)$. Ebből következik a nyírás lokális degenerációja nevú jelenség [5]: a $g_{1}+i g_{2}$ és $1 /\left(g_{1}-i g_{2}\right)$ nyírású ellipszis képek $\phi$ fázisa (azaz állása) és tengelyaránya megegyezik. A lokális degeneráció a gyakorlatban azt jelenti, hogy egy galaxis képéról nem lehet megállapítani, hogy "egyenes" vagy tükörkép. A lokális degenerációt csak olyan nagy térszögú megfigyeléssel lehet elkerülni, amelyen egy galaxis kétféle képe egyszerre megfigyelhetô. Ugyanis általában a lencsesíkon a pozitív paritású régió, ahol det $A(\theta)>0$, legalább egy nagyságrenddel nagyobb, mint a negatív paritású [5].

Mivel a galaxisok nem kör alakúak, a megfigyelt képek alakja az ún. saját ellipticitás és a nyírás közremúködésével jön létre. A nyírásra azzal a feltevéssel kapható becslés, hogy a galaxisok saját ellipticitásai véletlenszerúen irányítottak. Tetszőleges $I(\beta)$ fényesség eloszlású kiterjedt forrás látszólagos alaktorzulását adott $I_{0}$ fényesség értékekhez tartozó izofóta görbék alakváltozásaival értelmezzuik. Mivel a galaxisok (és izofótáik) nem pontosan elliptikus alakúak, ezért alakjuk jellemzésére az alábbi mennyiségeket vezették be.

Ha a kép fényességeloszlása $I(\theta)$, akkor a kép középpontját a

$$
\hat{\theta}:=\frac{\iint I(\theta) q(I(\theta)) \theta d^{2} \theta}{\iint I(\theta) q(I(\theta)) d^{2} \theta}
$$

kifejezéssel értelmezzük. A $q(I)$ súlyfüggvényt többféleképpen megválaszthatjuk. Ha $q(I)=$ $H\left(I-I_{\text {határ }}\right)$ (Heaviside függvény), akkor $\hat{\theta}$ a $I_{\text {határ fényességú határon belüli terület közép- }}$ pontja lesz. A második fényesség momentum tenzor

$$
Q_{i j}:=\frac{\iint I(\theta) q(I(\theta))\left(\theta_{i}-\hat{\theta}_{i}\right)\left(\theta_{j}-\hat{\theta}_{j}\right) \theta d^{2} \theta}{\iint I(\theta) q(I(\theta)) d^{2} \theta} .
$$

A komplex ellipticitás

$$
\chi=\frac{Q_{11}-Q_{22}+2 i Q_{12}}{Q_{11}+Q_{22}} .
$$

A középpont, a fényesség momentum és az ellipticitás hasonlóan definiálható a forrás esetében. A kép keletkezése során az ellipticitás transzformációjára

$$
\chi^{\text {forrás }}=\frac{\chi^{k e ́ p}-2 g+g^{2} \bar{\chi}^{k e ́ p}}{1+|g|^{2}-2 \operatorname{Re}\left(g \bar{\chi}^{k e ́ p}\right)} .
$$

érvényes [18] (a felülvonás komplex konjugálást jelöl). A képek ellipticitása tehát csak a $g$ redukált nyíráson keresztül függ az $A$ optikai leképezéstől.

Megjegyezzük, hogy a $\gamma=\gamma_{1}+i \gamma_{2}$ nyírás a képsíkban felvett derékszögú koordináta rendszer $\vartheta$ szögú elforgatásakor e ${ }^{-2 i \vartheta}$-val szorzódik. A $\gamma_{1}$ komponens tehát cos $2 \vartheta$-val, a $\gamma_{2}$ komponens pedig -sin $2 \vartheta$-val. Ezen transzformációs viselkedés alapján $\gamma$ nem vektor, hanem ún. polár [5]. 


\subsection{Tengelyszimmetrikus lencsék}

A legegyszerúbb lencse modellek felületi súrúsége tengelyszimmetrikus. A tengelyszimmetrikus lencsék felületi sưrúsége a $\xi$ helyvektor nagyságától függ: $\Sigma(\xi)=\Sigma(|\xi|)$ ill. $\kappa(\theta)=$ $\kappa(|\theta|)$. A galaxisok tömegeloszlásának modellezésre leggyakrabban az izotermális gömböket alkalmazzák [5]. Az izotermális jelző arra utal, hogy a bennük található részecskék sebessége Maxwell eloszlást követ. A szinguláris izotermális gömb tömegeloszlása a gömb középpontjában nem értelmezett:

$$
\rho(r)=\frac{\sigma_{v}^{2}}{2 \pi G r^{2}} .
$$

A Maxwell eloszlást a $\sigma_{v}$ sebességdiszperzió jellemzi. A fenti tömegeloszlást nagy távolságban jól közelíti a nem-szinguláris izotermális gömb, mely értelmezett a gömb középpontjában is (a $\theta_{c}$ szög egy karakterisztikus sugár):

$$
\kappa(\theta)=\kappa(0)\left(1+\frac{\theta^{2}}{2 \theta_{c}^{2}}\right)\left(1+\frac{\theta^{2}}{\theta_{c}^{2}}\right) .
$$

A (2.5) elhajlás vektor a tengelyszimmetria következtében az alábbi alakot ölti:

$$
\alpha(\theta)=2 \frac{\theta}{|\theta|^{2}} \int_{0}^{|\theta|} \kappa\left(\theta^{\prime}\right) \theta^{\prime} d \theta^{\prime} .
$$

Általános, azaz $\beta \neq 0$ helyzetú forrás esetén a fény az $O L S$ kitüntetett síkban terjed (2.2 ábra). Ezért a (2.6) lencseegyenlet egydimenzióssá válik; a (2.15) egyenletben $\beta$ pozitív szög és $\theta$ az előjeles látszó szög. Az $\alpha(\theta)$ elhajlás függvényre

$$
\alpha(\theta)=2 \frac{1}{\theta} \int_{0}^{\theta} \kappa\left(\theta^{\prime}\right) \theta^{\prime} d \theta^{\prime}
$$

adódik. Az $\alpha(\theta)$ függvény a (2.10) előjel konvenció szerint páratlan.

A Fermat potenciál [5]

$$
\tau(\theta)=\frac{1}{2}(\theta-\beta)^{2}-2 \int_{0}^{\theta} \kappa\left(\theta^{\prime}\right) \theta^{\prime} \ln \frac{\theta}{\theta^{\prime}} d^{2} \theta .
$$

A (2.22) definíció alapján a lencsék nagyító hatását a (2.20) mátrix determinánsának reciproka szolgáltatja. A tengelyszimmetrikus lencsék esetében [5]

$$
\operatorname{det} A=\frac{\beta}{\theta} \frac{d \beta}{d \theta} \text {. }
$$

A tengelyszimmetrikus lencsék határesete a pontszerú lencse. A pontszerú lencse által létrehozott képeket a (2.18) képlet adja meg. A (2.38) képlet alkalmazásával a pontszerú lencse képeinek nagyítása

$$
\mu_{ \pm}=\frac{1}{4}\left(\frac{1}{\beta} \sqrt{\beta^{2}+4 \theta_{E}^{2}}+\frac{\beta}{\sqrt{\beta^{2}+4 \theta_{E}^{2}}} \pm 2\right) .
$$

A nagyításokra $\mu_{+}-\mu_{-}=1$ teljesül. A $\beta \rightarrow 0$ határesetben a nagyítások nem korlátosak, az arányuk pedig 1-hez tart:

$$
\begin{aligned}
& \mu_{ \pm} \rightarrow \frac{\theta_{E}}{2 \beta} \pm \frac{1}{2}+\frac{3 \beta}{8 \theta_{E}}+\mathcal{O}\left(\beta^{2}\right) \\
& \frac{\mu_{+}}{\mu_{-}} \rightarrow 1+\frac{2 \beta}{\theta_{E}}+\frac{2 \beta^{2}}{\theta_{E}^{2}}+\mathcal{O}\left(\beta^{3}\right) .
\end{aligned}
$$

A pontszerú lencsére fennálló $(2.18,2.39,2.40)$ összefüggések a Schwarzschild fekete lyukra is érvényesek. Az alternatív gravitációelméletekben történő lencsézés leírásakor a Schwarzschild lencsézés a sztenderd viszonyítási alap ill. határeset. 


\section{3. fejezet}

\section{Gömbszimmetrikus fekete lyukak alternatív gravitációelméletekben}

Ebben a fejezetben az alternatív gravitációelméletek közül azt a hármat tekintjük át, amelyekben a gravitációs lencsézést fogjuk tanulmányozni a hátralévő fejezetekben.

Ha a 3+1 dimenziós téridőt extra térszerú dimenziókkal bővítjük, akkor új gravitációelméletekhez jutunk. A brán világ modellekben a standard modellből ismert anyag egy 3+1 dimenziós hiperfelületre, a bránra korlátozódik. A gravitáció egy nagyobb dimenziós téridőben hat. A bránon az Einstein egyenlet helyett az effektív Einstein egyenlet érvényes. Ennek vannak többek között brán fekete lyuk megoldásai is.

A Hořava-Lifshitz elmélet olyan térelméletek családja, amelyekben a téridőn egy kitüntetett fóliázást választunk, ezzel sértve a Lorentz invarianciát. Ezek az elméletek gravitációelméletként értelmezhetôk. Vannak kozmológiai és asztrofizikai alkalmazásai is. Kehagias és Sfetsos fekete lyuk megoldása aszimptotikusan sík, gömbszimmetrikus, sztatikus. A metrika a tömegtől és a Hořava-Lifshitz paramétertől függ.

A magasabbrendú gravitációelméletekben az Einstein egyenlet geometriai oldalát módosítják ahelyett, hogy egzotikus energia-impulzus tenzorokkal dolgoznának. Az $f(R)$ elméletekben az Einstein-Hilbert hatást kicseréljük a Ricci skalár valamilyen függvényére. Az egyenletek gömbszimmetrikus sztatikus vákuum megoldása egy kompakt égitestnek felel meg.

Az alternatív gravitációelméletekben történő lencsézés leírásakor a Schwarzschild lencsézés a természetes viszonyítási alap. Olyan határeset, amelyet minden alternatív gravitációelméletben meg kell kapni alkalmas határátmenetben.

\subsection{Brán világ elméletek}

Brán világokban sötét anyag nélkül magyarázhatók a galaxis forgás görbék és a galaxishalmazok röntgen sugárzási profilja [19], [20], [21].

A brán elméletben a brán egy szakadást képvisel a külső görbületben [22]-[24]. Fizikai értelmezéstől függôen a brán külsô görbületének ugrása disztribúcionális anyagot indukál a bránon, vagy a bránon lévő disztribúcionális anyag hoz létre ugrást a brán külső görbületében. Az indukált elméleteknek két főága van. Ezek a módosított Friedmann ill. Raychaudhuri egyenletek levezetésében fellépő négyzetgyökvonás során választott előjelnek felelnek meg [25]. A negatív előjelhez tartozó ágon találhatók az általánosított Randall-Sundrum 2-es típusú elméletek (RS2) és az LDGP elméletek. Az első RS2 modellben 5 dimenziós anti-de Sitter téridôbe ágyazott Minkowski brán szerepel [26]. Egy másikban a brán valamilyen nem elektromágneses sugárzást bocsát ki a magasabb dimenziós téridőbe. Megjegyezzük, hogy az indukált gravitációs modellek családja egy még általánosabb gravitációelméletbe (Dvali-Gabadadze-Porrazi elmélet [25], [27], [28]) sorolható be. 
Az RS2 asztrofizikai jóslatai: 5 dimenziós anti-de Sitter téridőbe szimmetrikusan beágyazott Minkowski brán esetén a Hulse-Taylor pulzár periódusidejének csökkenési üteme az ÁRE előrejelzésével vezető rendben megegyezik [98]. Ha a brán beágyazása szimmetrikus, akkor az Oppenheimer-Snyder kollapszus során az összeomló por külső téridője nem sztatikus [29]. Ha a magasabb dimenziós téridôben null por van vagy az összeomló ideális folyadék nem por, akkor a külső téridő lehet sztatikus [30], [31]. Az RS2-ben a korai kozmológiát vizsgálja a [21] cikk.

A gravitáció öt dimenzióban hat az 5 dimenziós Einstein egyenlet szerint:

$$
\widetilde{G}_{a b}=\widetilde{\kappa}^{2}\left[\widetilde{T}_{a b}+\tau_{a b} \delta(y)\right]=\widetilde{\kappa}^{2}\left[\widetilde{T}_{a b}+\left(\lambda q_{a b}+T_{a b}\right) \delta(y)\right] .
$$

$\widetilde{G}_{a b}$ az öt dimenziós Einstein tenzor, $\widetilde{\kappa}^{2}$ a gravitáció csatolási állandója az Einstein-Hilbert hatásban, $\widetilde{T}_{a b}+\tau_{a b} \delta(y)$ a magsabbdimenziós téridő energia-impulzus tenzora. $\widetilde{T}_{a b}$ a bránon kívül lévő nem-sztenderd anyag. Az energia-impulzus tenzor $\tau_{a b} \delta(y)$ disztribúcionális tagja azt fejezi ki, hogy a sztenderd kölcsönhatások és mezók a bránra korlátozódnak. $\lambda$-t brán feszültségnek nevezzük, $q_{a b}$ az indukált metrika a bránon, $T_{a b}$ a brán energia-impulzus tenzor.

Az öt dimenziós Einstein egyenlet következménye a Lánczos-Israel illesztési feltétel [32]:

$$
\Delta^{(4)} K_{a b}=-\widetilde{\kappa}^{2}\left(\tau_{a b}-\frac{\tau}{3} g_{a b}\right)
$$

${ }^{(4)} K_{a b}$ a brán külsô görbülete; tükörszimmetrikus beágyazás esetén $\Delta{ }^{(4)} K_{a b}=2{ }^{(4)} K_{a b}$ és a bránon lévő anyag meghatározza a brán külső görbületét ( $\Delta$ a tenzorok eltérését képzi a brán két oldala között).

Az öt dimenziós Einstein egyenletet a bránra vetítve, azt a brán két oldalán kiértékelve, majd a tenzorok átlagát képezve kapjuk az effektív Einstein egyenletet [33]:

$$
G_{a b}=-\left(\Lambda-\frac{\widetilde{\kappa}^{2}\langle\tilde{\pi}\rangle}{2}\right) g_{a b}+\kappa^{2} T_{a b}+\widetilde{\kappa}^{4} S_{a b}-\left\langle{ }^{(4)} \mathcal{E}_{a b}\right\rangle+\left\langle L_{a b}\right\rangle+\left\langle\mathcal{P}_{a b}\right\rangle
$$

A $\langle$.$\rangle zárójel képezi a mennyiségek átlagát a brán két oldalán kiértékelve. A \Lambda$ a kozmológiai állandó a bránon. $S_{a b}$ az energia-impulzus tenzorban négyzetes tag, $\mathcal{P}_{a b}$ és $\widetilde{\pi}$ az 5 dimenziós téridő anyagi járulékai, $L_{a b}$ a brán beágyazásából származó tag, ${ }^{(4)} \mathcal{E}_{a b}$ az 5 dimenziós Weyl tenzor projekciója.

\subsubsection{Az árapálytöltésú fekete lyuk}

A fekete lyuk megoldások a brán elméletekben is fontosak. Az analitikus fekete lyuk megoldások között van 6 dimenziós lokális Schwarzschild megoldás [34]; sztatikus 5 dimenziós fekete lyuk a bránon, olyan horizonttal ami az extra dimenzióban felbomlik és energia feltételt sértő héjak keltik [35], [36]; és fekete lyuk az extra dimenzióban lévő sugárzó komponenssel [37]. Numerikusan az 5 dimenziós görbülethez képest kicsi brán fekete lyukak létezését mutatták ki. Ezek 5 dimenziós Schwarzschild megoldások aszimptotikusan sík 5 dimenziós anti-de Sitter téridőben [38]. A 4 dimenziós Schwarzschild metrika kiterjeszthető az 5. dimenzióba fekete húrként [39]. A fekete húr gravitációs hullám perturbációit a [40] cikkben számolták ki. A gömbszimmetrikus forrás gravitációs mezőjének perturbatív elemzése a gyenge tér határesetben korrekciókat mutatott ki a Schwarzschild potenciálhoz képest. Ezek skálája $r^{-3}$, amikor a brán Schwarzschild fekete lyuk be van ágyazva egy 5 dimenziós anti-de Sitter téridôbe [41], [42]. Ha a Schwarzschild fekete lyuk egy másféle magasabb dimenziós téridőbe van beágyazva, akkor eltérő skálázás érvényes [43].

Az effektív Einstein egyenletnek az 1 kodimenziós bránon van egy sztatikus, gömbszimmetrikus, vákuum megoldása, amit két paraméter jellemez: az $m$ tömeg és a $q$ árapálytöltés 
[44]:

$$
\begin{aligned}
d s^{2} & =-f(r) d t^{2}+f^{-1}(r) d r^{2}+r^{2}\left(d \theta^{2}+\sin ^{2} \theta d \varphi^{2}\right) \\
f & =1-\frac{2 m}{r}+\frac{q}{r^{2}} .
\end{aligned}
$$

Az árapálytöltés annak a téridőnek a Weyl görbületéből származik, amelybe a brán be van ágyazva. $q \leq m^{2}$ esetben a metrika egy fekete lyukat ír le, melynek horizontjai $r_{ \pm}=m \pm$ $\left(m^{2}-q\right)^{1 / 2}$. Ha $q<0$ akkor csak $r_{+}$pozitív, tehát csak 1 horizont van. Ha $q=0$ akkor az ívelem az Schwarzschild metrikát írja le és $0<q \leq m^{2}$ esetben formálisan azonos a Reissner-Nordström megoldással, melynek elektromos töltése $Q=q^{1 / 2}$. A $q$ árapálytöltés hasonló szerepet játszik mint az ÁRE-ben a Reissner-Nordström fekete lyuk elektromos töltésének négyzete. Azonban a negatív árapálytöltésnek nincs megfelelője az ÁRE-ben. A $q=m^{2}$ határesetben a metrika extrémálissá válik és a két horizont egybeesik. A $q>m^{2}$ esetben egyáltalán nincs horizont. Ekkor a metrika szinguláris $r=0$-ban, tehát csupasz szingularitást ír le. A negatív árapálytöltés erôsíti a gravitációt (a horizont kívül esik a $2 m$ Schwarzschild sugáron). Ezt termodinamikai megfontolások is alátámasztják [45]. A pozitív árapálytöltés gyengíti a gravitációt, mert mindkét horizont a Schwarzschild sugár alatt van a $0<q \leq m^{2}$ esetben.

Megfigyelések alapján kényszerek számolhatók ki a téridő $\lambda$ bránfeszültségére. A Naprendszerben a fényelhajlási szög vizsgálatából kapott kényszer $\lambda>6.31 \times 10^{-3} \mathrm{MeV}^{4}$ [46]. A bránon lévő neutroncsillag állapotegyenlete alapján, az egyenletet konstans sứrúségú átlagos tömegú neutron csillagra alkalmazva $\lambda>5 \times 10^{8} \mathrm{MeV}^{4}$ [97] adódik. További kényszerek adódnak a kettős neutroncsillagok oszcillációjának modelljeiből [47], és a Föld perihélium precessziójából [48].

\subsection{Hořava-Lifshitz elméletek}

A Hořava-Lifshitz elméletek $[49,50]$ az Arnowitt-Deser-Misner formalizmusnak [102] nemsztenderd kiterjesztései. A téridőn egy kitüntetett fóliázást választunk, ezzel sértjük a Lorentz invarianciát. Az Einstein-Hilbert hatást felbontjuk a $\mathcal{T}=K^{i j} K_{i j}-(\xi-1) K^{2}$ kinetikus tag és egy potenciális tag összegére. A $\xi$ paraméter $\xi \rightarrow 1$ határesetében az ÁRE adódik. Végül ezekhez az összetevőkhöz külön-külön hozzáadunk extra tagokat. Olyan térelméletet kapunk, ami gravitációelméletként értelmezhetô.

A Hořava-Lifshitz elméleteknek sok változata van. Az alábbi hatás 3+1 dimenzióban érvényes és az extra tagok csak görbületi invariáns skalároktól függenek [51]:

$$
\begin{aligned}
\mathcal{S}= & \mathcal{S}_{E H}+\mathcal{S}_{L V}, \\
\mathcal{S}_{E H}= & \zeta^{2} \int \sqrt{-g} N\left(K^{i j} K_{i j}-K^{2}+R-g_{0} \zeta^{2}\right) d^{3} x d t, \\
\mathcal{S}_{L V}= & \zeta^{2} \int \sqrt{-g} N\left(\xi K^{2}-g_{2} \zeta^{-2} R^{2}-g_{3} \zeta^{-2} R^{i j} R_{i j}-g_{4} \zeta^{-4} R^{3}-g_{5} \zeta^{-4} R R^{i j} R_{i j}\right. \\
& \left.-g_{6} \zeta^{-4} R_{j}^{i} R_{k}^{j} R_{i}^{k}-g_{7} \zeta^{-4} R \nabla^{2} R-g_{7} \zeta^{-4} \nabla_{i} R_{j k} \nabla^{i} R^{j k}\right) d^{3} x d t .
\end{aligned}
$$

A $\left(g_{0} \zeta^{2}=2 \Lambda\right.$ kozmológiai állandóval bővített) Einstein-Hilbert hatáshoz $\left(\mathcal{S}_{E H}\right)$ hozzáadtunk Lorentz invarianciát sértő tagokat $\left(\mathcal{S}_{L V}\right)$. Majdnem minden Hořava-Lifshitz elméletben megjelenik az ún. vetíthetőségi feltétel, amit a kitüntetett fóliázás alkalmas megválasztásával a teljes téridőn (azaz globálisan) ki lehet kényszeríteni. A feltétel szerint a lapse függvényre $N(x, t)=N(t)$. (Az ÁRE-ben ezt általában csak lokálisan tudjuk elérni. Az asztrofizikailag jelentôs téridőkben lehetséges téridő tartományokban is teljesíteni a feltételt. Pl. a ReissnerNordstöm téridőben a belsô horizonton kívül Painlevé-Gullstrand koordinátákban tejesül. A 
Kerr téridőben pedig globálisan fennáll Doran koordinátákban [51].) A hatásból levezethető egy 0 spinú mező megjelenése a dinamikában, amelyet skaláris graviton módusnak neveznek. Ez problémát jelent kísérleti szempontból [51]: a kettôs pulzárok energiavesztése nagyobb mint az ÁRE-ben, ami megfigyelhetô eltérést okoz a pályamozgásban. A szabadesés gyorsulása tömegtôl függôvé válik.

Ultraibolya energiaskálán anizotróp Lifshiz skálázás jelenik meg az elméletben a tér és az idő között a $x^{i} \rightarrow l x^{i}$ és $t \rightarrow l^{z} t$ transzformációknak megfelelően, ahol $z$ a skálakitevő (ebből ered az Hořava-Lifshitz elnevezés). Az alkalmazások közé tartozik a kozmológia, a sötét anyag, a sötét energia ill. a gömbszimmetrikus vagy forgó téridők tanulmányozása.

\subsubsection{A Kehagias-Sfetsos fekete lyuk}

A Hořava-Lifshitz elméletben az alábbi aszimptotikusan sík, gömbszimmetrikus, sztatikus téridôt vezették le a [52] cikkben:

$$
d s^{2}=g_{t t}(r) d t^{2}+g_{r r}(r) d r^{2}+r^{2}\left(d \Theta^{2}+\sin ^{2} \Theta d \varphi^{2}\right) .
$$

A metrikus függvények

$$
-g_{t t}(r)=1 / g_{r r}(r)=1+\omega r^{2}\left[1-\left(1+\frac{4 m}{\omega r^{3}}\right)^{1 / 2}\right] .
$$

$\omega$ az ún. Hořava-Lifshitz (HL) paraméter és $m:=M G / c^{2}$ ( $M$ a fekete lyuk tömege, $G$ a gravitációs állandó, $c$ a fénysebesség). Az $\omega_{0} \rightarrow \infty$ limesz a Schwarzschild metrika, a $\omega_{0} \rightarrow$ 0 határeset pedig a sík téridô. Utóbbi esetben a Kehagias-Sfetsos téridő anélkül válik síkká, hogy a Schwarzschild határesetet megközelítené. Ehelyett csupasz szingularitássá válik, amely egyébként elvben gond nélkül illeszthető valamilyen csillag megoldással, miután a szingularitás környezetét eltávolítottuk.

A (3.5) Kehagias-Sfetsos téridônek görbületi szingularitása van az origóban. Az $\omega_{0}=m^{2} \omega$ dimenziótlan mennyiség hasznosnak bizonyult a (3.5) téridő naprendszerbeli tesztjeiben [89]. $\mathrm{Az}$

$$
r_{ \pm}=m\left(1 \pm \sqrt{1-\frac{1}{2 \omega_{0}}}\right)
$$

koordináta szingularitások kitranszformálhatók a $(v, r)$ Eddington-Finkelstein típusú koordináták koordináták bevezetésével. $r_{+}$a látszó- és esemény horizont, kielégíti a $d r / d v=0$ definíciót. Az $\omega_{0} \rightarrow \infty$ határesetben $r_{+}$a Schwarzschild horizonthoz $(r=2 m)$ tart, $r_{-}$pedig a görbületi szingularitáshoz. $r_{ \pm}$képzetes, ha $\omega_{0} \leq 1 / 2 \equiv \omega_{0}^{\text {extr }}$, ekkor a metrika csupasz szingularitást ír le. Az

$$
\omega_{0}>\frac{1}{2}
$$

egyenlőtlenségre fekete lyuk feltétel néven fogunk hivatkozni. 


\section{3. $\mathbf{f}(\mathbf{R})$ elméletek}

A megfigyelések nem egyeztethetôk össze az ÁRE-vel, ha abban a sztenderd anyagi forrásokat alkalmazzuk. Ilyen megfigyelések az I.a típusú szupernóva standard gyertyák, a szuperhalmazok és a galaktikus rotációs görbék [53, 54, 55]. A megfigyelések magyarázatához az Einstein egyenlet módosítandó. Ez vagy nem-sztenderd anyagnak az energia-impulzus tenzorhoz adását vagy a gravitációs dinamika lecserélését jelenti.

Ahhoz, hogy a megfigyeléseket az ÁRE keretein belül értelmezzük, be kellett vezetni a sötét anyagot és a sötét energiát. Ez az ára az Einstein-Hilbert hatás megôrzésének. A sötét anyagot és a sötét energiát azonban még nem észlelték kísérletileg.

A magasabbrendû́ gravitációelméletekben az Einstein egyenlet geometriai oldalát módosítják ahelyett, hogy egzotikus energia-impulzus tenzorokkal dolgoznának. Ezek az elméletek metrikus formalizmusban [58, 57, 56, 59], és Palatini formalizmusban is [61, 62, 60, 63] tárgyalhatók. A Hubble áramlásra és a nagy léptékû struktúrák fejlődésére vonatkozó megfigyelésekkel jó egyezést mutatnak. A pontszerú tömeg gravitációs potenciálja módosul. Ennek következményei vannak a galaktikus dinamikára.

Az $f(R)$ elméletek a legtermészetesebb bővítései az ÁRE-nek. Az Einstein-Hilbert hatást kicseréljük az $R$ Ricci skalár valamilyen függvényére [58]. A hatás funkcionál alakja

$$
\mathcal{A}=\int d^{4} x \sqrt{-g}\left[f(R)+\mathcal{L}_{m}\right]
$$

ahol $f(R)$ az $R$ legalább kétszer deriválható függvénye, $g$ a metrika determinánsa és $\mathcal{L}_{m}$ az anyag Lagrange súrúsége. A hatást a metrika komponensei szerint variálva a mezőegyenleteket kapjuk, amelyeket az alábbi alakba lehet átírni:

$$
\begin{aligned}
R_{\mu \nu}-\frac{R}{2} g_{\mu \nu}= & G_{\mu \nu}=\frac{1}{f^{\prime}(R)}\left\{\frac{1}{2} g_{\mu \nu}\left[f(R)-R f^{\prime}(R)\right]+\nabla_{v} \nabla_{\mu} f^{\prime}(R)-g_{\mu \nu} g^{c d} \nabla_{c} \nabla_{d} f^{\prime}(R)\right\} \\
& +\frac{T_{\mu \nu}^{(m)}}{f^{\prime}(R)}
\end{aligned}
$$

$T_{\mu \nu}^{(m)}$ az anyag energia-impulzus tenzora. A ' az $R$ szerinti deriválást jelenti. Az $\nabla_{v} \nabla_{\mu} f^{\prime}(R)$ és $g^{c d} \nabla_{c} \nabla_{d} f^{\prime}(R)$ tagokban a metrika negyedrendú deriváltjai szerepelnek, ezért nevezik ezt az elméletet negyedrendú elméletnek.

\subsubsection{Gömbszimmetrikus kompakt égitest az $f(R)=R^{n}$ elméletben}

Ebben a szakaszban a (3.9) egyenlet gömbszimmetrikus, sztatikus, vákuum megoldását vezetjük le [4]. A metrika alakja

$$
d s^{2}=-A(r) d t^{2}+B(r) d r^{2}+r^{2} d \theta^{2}+r^{2} \sin ^{2} \theta d \varphi^{2} .
$$

A (3.9) egyenlet nyoma

$$
3 \square f^{\prime}(R)+R f^{\prime}(R)-2 f(R)=0 .
$$

A nyomot a 00 komponenssel kombinálva az

$$
f^{\prime}(R)\left(3 \frac{R_{00}}{g_{00}}-R\right)+\frac{1}{2} f(R)-3 \frac{\nabla_{0} \nabla_{0} f^{\prime}(R)}{g_{00}}=0 .
$$

egyenlet adódik [66]. 


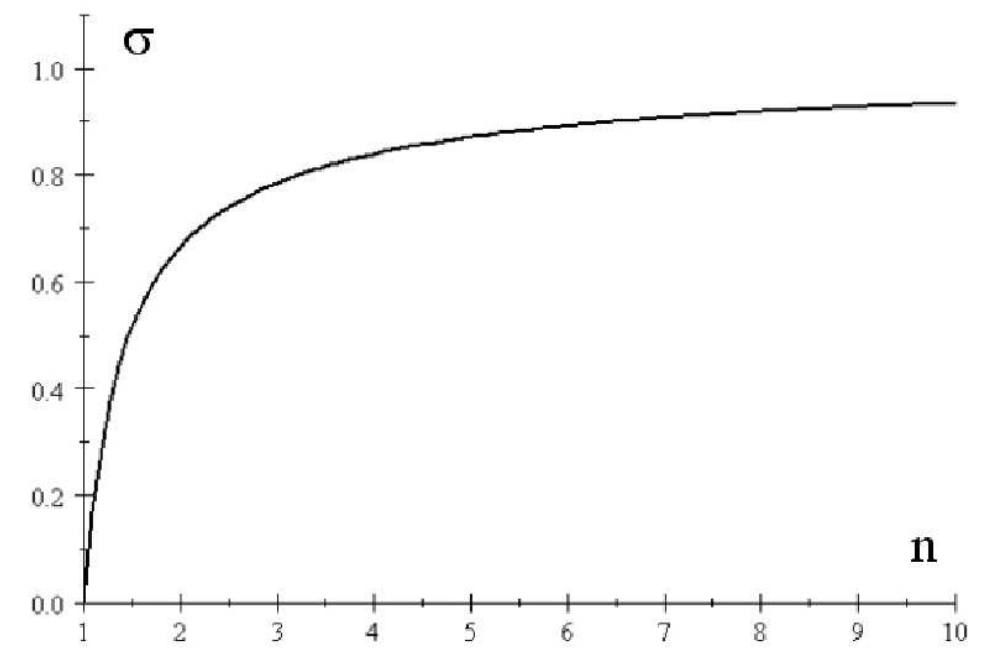

3.1. ábra. A $\sigma$ korrekciós paraméter az $n$ kitevő függvényében.

A továbbiakban $f(R) \propto R^{n}$, az így adódó speciális elméletet nevezzük el $R^{n}$ gravitációelméletnek. Ezzel a feltevéssel a (3.12) egyenlet

$$
R_{00}(r)=\frac{2 n-1}{6 n} A(r) R(r)-\frac{n-1}{2 B(r)} \frac{d A(r)}{d r} \frac{d \ln |R(r)|}{d r}
$$

alakú, a nyom egyenlet pedig

$$
\square R^{n-1}(r)=\frac{2-n}{3 n} R^{n}(r) .
$$

Az (3.13) és (3.14) egyenletek csatolt differenciálegyenlet rendszert alkotnak az $A(r)$ és $B(r)$ függvényekre. Ha $n=1$, akkor az (3.14) egyenletből $R=0$ következik. Ezt behelyettesítve az (3.13) egyenletbe, $R_{00}=0$ adódik és a megoldás a Schwarzschild téridő (bár a (3.13) egyenlet levezetése (3.12)-ből az $R \neq 0$ feltevéssel történt [67]).

Az egyenletrendszer kis energiájú közelítésének van megoldása [67]. Egy Schwarzschild téridőhöz hasonló megoldás alakja

$$
A(r)=\frac{1}{B(r)}=1+\frac{2 \Phi(r)}{c^{2}},
$$

ahol $\Phi(r)$ a gravitációs potenciál az $m$ tömegú ponttól $r$ távolságban. További feltevés, hogy a $\Phi_{N}(r)=1 / r$ newtoni potenciáltól való eltérést a

$$
\Phi\left(r ; \sigma, r_{c}\right)=-\frac{G m}{2 r}\left[1+\left(\frac{r}{r_{c}}\right)^{\sigma}\right]
$$

alakban vezetjük be. $\sigma$ a gravitáció erősségét jellemző paraméter és $r_{c}$ egy karakterisztikus távolságskála.

Ha $\sigma=0$, akkor a newtoni potenciál adódik, a metrika pedig Schwarzschild. Ha $\sigma=1$, akkor a korrekció állandó, így a metrika nem lehet aszimptotikusan sík. A potenciál korlátlanul nô, ha $\sigma>1$. Ezért a továbbiakban $\sigma \in[0,1)$. A $\Phi(r)$ potenciált behelyettesítjük a (3.13) és (3.14) egyenletbe. Két algebrai egyenletet kapunk, amelyekből egy összefüggés következik $\sigma$ és $n$ között:

$$
(n-1)(\sigma-3)\left[-\sigma(1+\sigma) V_{1} \eta^{\sigma-3}\right]^{n-1}\left[\mathcal{P}_{1}+\frac{\sigma}{\eta} V_{1} \mathcal{P}_{0}\right]=0
$$


ahol

$$
\begin{aligned}
\eta= & r / r_{c}, \quad V_{1}=G m / c^{2} r_{c}, \\
\mathcal{P}_{0}= & 3(\sigma-3)^{2} n^{3}-\left(5 \sigma^{2}-31 \sigma+48\right) n^{2}-\left(3 \sigma^{2}-16 \sigma+17\right) n-\left(\sigma^{2}-4 \sigma-5\right), \\
\mathcal{P}_{1}= & 3(\sigma-3)^{2}(1-\sigma) n^{3}+(\sigma-3)^{2}(5 \sigma-7) n^{2} \\
& -\left(3 \sigma^{3}-17 \sigma^{2}+34 \sigma-36\right) n+\left(\sigma^{2}-3 \sigma-4\right) \sigma .
\end{aligned}
$$

A (3.17) egyenlet megoldásai közül eltekintünk az $n=1$ (ill. $\sigma=0$ ) Schwarzschild esettől és a $\sigma=3$ esettől. A $\left[-\sigma(1+\sigma) V_{1} \eta^{\sigma-3}\right]^{n-1}$ tényezó 0 lenne a $\sigma=-1$ értékre, de ezt már kizártuk a $\sigma \in[0,1)$ feltevéssel. Ezért a

$$
\left[\mathcal{P}_{1}+\frac{\sigma}{\eta} V_{1} \mathcal{P}_{0}\right]=0
$$

egyenletet megoldását keressük. A megoldás zárt alakban bonyolult és $\eta$-függő, ezáltal $r$ függô. Ha azonban $r_{c}$ nagy távolság, akkor $V_{1} \ll 1$ kis posztnewtoni paraméterként viselkedik. Ha feltesszük, hogy $n$ egység nagyságrendű, akkor $\mathcal{P}_{0}$ és $\mathcal{P}_{1}$ összemérhető. Ekkor, a posztnewtoni tartományban a

$$
\mathcal{P}_{1}(n, \sigma) \eta=0
$$

egyenlet a megoldandó. A (3.18) egyenlet már nem $r$ függő, csupán a $\sigma$ és az $n$ között teremt algebrai kapcsolatot. Ezzel az egyszerúsítéssel az egzakt téridő megoldás levezetésének lehetôségét elvesztettuik, azonban a (3.18) egyenlet megoldásával a (3.13)-(3.14) egyenletrendszer közelítő, kis energiájú, távoli tér megoldását kapjuk [67]:

$$
\begin{aligned}
\sigma & =\left\{\begin{array}{l}
\frac{3 n-4}{n-1} \\
\frac{12 n^{2}-7 n-1-\sqrt{p(n)}}{q(n)} \\
\frac{12 n^{2}-7 n-1+\sqrt{p(n)}}{q(n)}
\end{array}\right. \\
p(n) & =36 n^{4}+12 n^{3}-83 n^{2}+50 n+1, \quad q(n)=6 n^{2}-4 n+2 .
\end{aligned}
$$

Csak a (3.19) megoldásnak van newtoni határesete (azaz $(n, \sigma)=(1,0)$ ), fizikailag ez értelmes.

Tehát a (3.9) mezóegyenlet gömbszimmetrikus, sztatikus, vákuum megoldását a kis energiájú, távoli tér közelítésben a (3.15), (3.16) és

$$
\sigma(n)=\frac{12 n^{2}-7 n-1-\sqrt{36 n^{4}+12 n^{3}-83 n^{2}+50 n+1}}{6 n^{2}-4 n+2}
$$

összefüggések szolgáltatják. A $\sigma(n)$ függvényt a 3.1 ábrán mutatjuk be. A $\sigma$ kitevô a (3.16) potenciálban univerzális mennyiség, mert csak a Lagrange sưrúség $n$ kitevőjétôl függ. Az $r_{c}$ hosszskála viszont azokkal az integrációs állandókkal kapcsolatos, amelyeknek értéket adunk a negyedrendû egyenletek megoldása során. Az $r_{c}$ sugár egy második gravitációs sugárnak tekinthető a Schwarzschild sugár mellett, ami abból származik, hogy az ÁRE másodrendú elmélet. A negyedrendú elmélet a gravitációs mező két további szabadsági fokát tartalmazza. Ez a paraméter nem univerzális, hanem az egyes gravitációsan kötött rendszerek sajátossága. A rendszer tipikus tömeg- és hosszskálájától függôen különbözô értékeket vehet fel.

\subsubsection{Energiafeltételek a kis energiájú, távoli tér tartományban}

A kis energiájú, távoli tér megoldás, amit a (3.10), (3.15), (3.16) és (3.20) összefüggések írnak le, vákuumban érvényes. Ezért nincsenek megfigyelhető energiafeltételek. A (3.9) egyenlet 
első tagja azonban egy geometriai eredetû, effektív energia-impulzusként értelmezhetô. Ebben a szakaszban belátjuk, hogy ez az ún. görbületi folyadék sérti a szokásos energiafeltételeket.

Ha a metrikát felbontjuk

$$
g_{\mu \nu}=-u_{\mu} u_{\nu}+n_{\mu} n_{\nu}+h_{\mu \nu}
$$

alakban $\left(h_{\mu \nu}\right.$ a gömbfelszín metrikája, $u^{\mu}=(1 / \sqrt{A}, 0,0,0)$ az idôszerú egységvektor, és $n^{\mu}=(0, \sqrt{A}, 0,0)$ a radiális egységvektor), akkor a gömbszimmetrikus sztatikus görbületi folyadék felbontása

$$
T_{\mu \nu}=\rho u_{\mu} u_{\nu}+p_{r} n_{\mu} n_{\nu}+p_{t} h_{\mu \nu}=\left(\rho+p_{t}\right) u_{\mu} u_{\nu}+\left(p_{r}-p_{t}\right) n_{\mu} n_{\nu}+p_{t} g_{\mu \nu} .
$$

$\rho$ az energiasûrûség, $p_{r}$ és $p_{t}$ a radiális és tangenciális nyomások:

$$
\begin{aligned}
\rho & =T_{\mu \nu} u^{\mu} u^{\nu}=T_{00}, \\
p_{r} & =T_{\mu \nu} n^{\mu} n^{\nu}=T_{11}, \\
p_{t} & =\frac{1}{2}\left(T_{\mu \nu} h^{\mu \nu}\right)=\frac{T_{22}}{r^{2}} .
\end{aligned}
$$

Az ekvivalens energia-impulzus az $R^{n}$ elméletben

$$
\begin{aligned}
T_{\mu \nu}^{\text {equiv }}= & (1-n) \times \\
& \left\{\frac{1}{2 n} g_{\mu \nu} R+\left(g_{\mu}^{\rho} g_{\nu}^{\sigma}-g_{\mu \nu} g^{\rho \sigma}\right)\left[(1-n) \nabla_{\rho}(\ln |R|) \nabla_{\sigma}(\ln |R|)-\nabla_{\rho} \nabla_{\sigma}(\ln |R|)\right]\right\} .
\end{aligned}
$$

Ha $n=1$ akkor $T_{\mu \nu}^{e q u i v}=0$. A görbületi skalár

$$
R=\frac{2(A-1)}{r^{2}}+\frac{4 A_{, r}}{r}+A_{, r r}=-\sigma(\sigma+1) \frac{G m}{c^{2} r_{c}^{\sigma}} r^{\sigma-3}
$$

ahol

$$
\begin{aligned}
\nabla_{\sigma} \ln |R| & =\frac{(\sigma-3)}{r} \delta_{\sigma}^{1}, \\
\nabla_{\rho} \nabla_{\sigma}(\ln |R|) & =-\frac{(\sigma-3)}{r^{2}} \delta_{\rho}^{1} \delta_{\sigma}^{1}-\frac{(\sigma-3)}{r} \Gamma_{\rho \sigma}^{1},
\end{aligned}
$$

és az előforduló Christoffel szimbólumok

$$
\begin{aligned}
\Gamma_{00}^{1} & =-\Gamma_{11}^{1}=\frac{A A_{, r}}{2}=\frac{G m}{2 c^{2} r^{2}}\left[1+(1-\sigma)\left(\frac{r}{r_{c}}\right)^{\sigma}\right]\left(1-\frac{G m}{c^{2} r}\left[1+\left(\frac{r}{r_{c}}\right)^{\sigma}\right]\right) \\
& \approx \frac{G m}{2 c^{2} r^{2}}\left[1+(1-\sigma)\left(\frac{r}{r_{c}}\right)^{\sigma}\right], \\
\Gamma_{22}^{1} & =\frac{\Gamma_{33}^{1}}{\sin ^{2} \theta}=-r A=-r\left(1-\frac{G m}{c^{2} r}\left[1+\left(\frac{r}{r_{c}}\right)^{\sigma}\right]\right) .
\end{aligned}
$$

$\mathrm{A} \approx$ jel a sorfejtésre utal a $G m / c^{2} r$ posztnewtoni paraméterben első rendig.

Tehát az ekvivalens energia-impulzus

$$
\begin{aligned}
T_{\mu \nu}^{\text {equiv }}= & (1-n) g_{\mu \nu}\left\{-\frac{\sigma(\sigma+1) G m}{2 n c^{2} r_{c}^{\sigma}} r^{\sigma-3}+\frac{(\sigma-3)}{r^{2}}\left[[1+(1-n)(\sigma-3)] A+r g^{\rho \sigma} \Gamma_{\rho \sigma}^{1}\right]\right\} \\
& +(1-n) \frac{(\sigma-3)}{r^{2}}\left\{[(1-n)(\sigma-3)+1] g_{\mu}^{1} g_{\nu}^{1}+r \Gamma_{\mu \nu}^{1}\right\}
\end{aligned}
$$


Az alábbi részeredményből

$$
\begin{aligned}
g^{\rho \sigma} \Gamma_{\rho \sigma}^{1}= & \frac{\left(1-A^{2}\right) A_{, r}}{2}+2 r^{-1} A \\
= & \frac{1}{4 r}\left(\frac{G m}{c^{2} r}\right)^{2}\left[1+\left(\frac{r}{r_{c}}\right)^{\sigma}\right]\left[1+(1-\sigma)\left(\frac{r}{r_{c}}\right)^{\sigma}\right]\left(1-\frac{G m}{4 c^{2} r}\left[1+\left(\frac{r}{r_{c}}\right)^{\sigma}\right]\right) \\
& +2 r^{-1}\left\{1-\frac{G m}{2 c^{2} r}\left[1+\left(\frac{r}{r_{c}}\right)^{\sigma}\right]\right\} \\
\approx & 2 r^{-1}\left\{1-\frac{G m}{2 c^{2} r}\left[1+\left(\frac{r}{r_{c}}\right)^{\sigma}\right]\right\}
\end{aligned}
$$

és a (3.23) egyenletből az alábbi, elsô posztnewtoni rendú kifejezéseket kapjuk:

$$
\begin{aligned}
\rho & =\frac{n-1}{r^{2}}\left(\rho_{r}^{0}-\frac{G m}{c^{2} r} \rho_{r}^{1}\right), \\
p_{r} & =\frac{1-n}{r^{2}}\left(p_{r}^{0}-\frac{G m}{c^{2} r} p_{r}^{1}\right), \\
p_{t} & =\frac{1-n}{r^{2}}\left(p_{t}^{0}-\frac{G m}{c^{2} r} p_{t}^{1}\right) .
\end{aligned}
$$

A vezető rendû járulékok

$$
\begin{aligned}
\rho_{r}^{0} & =\frac{n-1}{r^{2}}(\sigma-3)[3+(n-1)(3-\sigma)], \\
p_{r}^{0} & =2 \frac{1-n}{r^{2}}(\sigma-3)[2+(n-1)(3-\sigma)], \\
p_{t}^{0} & =\frac{1-n}{r^{2}}(\sigma-3)[2+(n-1)(3-\sigma)],
\end{aligned}
$$

a posztnewtoni járulékok

$$
\begin{aligned}
& \rho_{r}^{1}=2 \rho_{r}^{0}+\frac{(\sigma-3)}{2}+\left(2 \rho_{r}^{0}+\rho_{c}^{1}\right)\left(\frac{r}{r_{c}}\right)^{\sigma}, \\
& p_{r}^{1}=\frac{\sigma-3}{2}+\rho_{c}^{1}\left(\frac{r}{r_{c}}\right)^{\sigma}, \\
& p_{t}^{1}=p_{t}^{0}+\left[p_{t}^{0}+\frac{\sigma(\sigma+1)}{2 n}\right]\left(\frac{r}{r_{c}}\right)^{\sigma} .
\end{aligned}
$$

(Alkalmaztuk a

$$
\rho_{c}^{1}=\frac{1}{2}\left[\frac{\sigma(\sigma+1)}{n}+(1-\sigma)(\sigma-3)\right]
$$

jelölést.)

A továbbiakban többféle energiafeltételt tárgyalunk, amelyeknek a (3.22) anizotróp folyadék engedelmeskedhet.

i) Gyenge energiafeltétel: $\rho \geq 0, \rho+p_{r}>0$ és $\rho+p_{t}>0$.

ii) Null energiafeltétel: $\rho+p_{r} \geq 0$ és $\rho+p_{t} \geq 0$.

iii) Erôs energiafeltétel: $\rho+p_{r} \geq 0, \rho+p_{t} \geq 0$ és $\rho+p_{r}+2 p_{t} \geq 0$.

iv) Domináns energiafeltétel: $\rho \geq 0, \rho \geq\left|p_{r}\right|$ és $\rho \geq\left|p_{t}\right|$. 
A gyenge tér közelítésben a vezető rendű járulékok

$$
\begin{aligned}
\rho_{r}^{0} & =-\frac{(n-1)(3-\sigma)}{r^{2}}[3+(n-1)(3-\sigma)] \leq 0, \\
\rho^{0}+p_{r}^{0} & =\frac{(n-1)(3-\sigma)}{r^{2}}[1+(n-1)(3-\sigma)] \geq 0, \\
\rho^{0}+p_{t}^{0} & =-\frac{(n-1)(3-\sigma)}{r^{2}} \leq 0, \\
\rho^{0}+p_{r}^{0}+2 p_{t}^{0} & =\frac{(n-1)(3-\sigma)}{r^{2}}[5+3(n-1)(3-\sigma)] \geq 0 .
\end{aligned}
$$

Az egyenlőtlenségek az $n \geq 1$ és $\sigma \in[0,1)$ feltevésekből következnek. Ha $n \neq 1$, akkor a görbületi folyadék sérti az összes energiafeltételt. Ezen a megállapításon az elsô rendú posztnewtoni tagok nem változtatnak. 


\section{4. fejezet}

\section{Az árapálytöltésú fekete lyuk gravitációs lencsézése}

Ebben a fejezetben képek keletkezését, helyzetüket és fényességüket tárgyaljuk, olyan fekete lyukak jelenlétében, amelyek létezését az 5 dimenziós brán világ elméletek jósolják [1], [2]. Gyenge és erôs lencsézést is tanulmányoztak már különféle brán fekete lyukak jelenlétében [70], [71], [72]. A témakört a [73] cikk foglalja össze. A fényelhajlás által okozott jelenségek megfigyelése kényszereket állít fel a lencsézô fekete lyuk paramétereire és a háttérben múködő gravitációelméletre is. A $q$ árapálytöltésre és a $\lambda$ bránfeszültségre a [46], [48] cikkek kényszereket állapítottak meg, naprendszerbeli megfigyelések alapján.

Ebben a fejezetben a $G=1=c$ egységekben dolgozunk.

\subsection{Gyenge gravitációs lencsézés árapálytöltésú fekete lyuk jelenlétében}

A Schwarzschild fekete lyuk lencsézési tulajdonságait a [11] cikkekben vizsgálták. Mindaddig amíg a fénysugár impakt paramétere vagy a legközelebbi megközelítés távolsága nagy az árapálytöltéshez társított természetes távolságskálához képest, a gyenge tér határeset létezik. Ekkor a fényelhajlás hatásai analitikusan számolhatók. A [46] cikkben az árapálytöltésú fekete lyuk mellett elhaladó fénysugarak fényelhajlási szögét perturbációszámítással másodrendig számolták ki. A fényelhajlás az $\varepsilon:=m / b$ és $\eta:=q / b^{2}$ kis paraméterekben került levezetésre ( $b$ az impakt paraméter). Az elhajlási szög másodrendú pontosságig

$$
\delta=4 \varepsilon-\frac{3}{4} \pi \eta+\frac{15}{4} \pi \varepsilon^{2}-16 \varepsilon \eta+\frac{105}{64} \pi \eta^{2} .
$$

A hamiltoni módszer alkalmazása a korábban használt Lagrange módszerrel azonos eredményt adott [74].

Az alábbiakban levezetünk egy lencseegyenletet és alkalmazzuk az árapálytöltésú brán fekete lyukak által létrehozott képek tanulmányozására. Az egyenlet általánosabb mint a VirbhadraEllis lencseegyenlet, és egy megfelelően definiált közelítésben arra egyszerúsödik. Tárgyaljuk a hasonlóságokat és kimutatjuk a különbségeket a Schwarzschild fekete lyuk lencsézéséhez képest. A tömeg dominált gyenge lencsézés esetében elemezzük a képek helyzetét, a nagyítási tényezőket és a fluxusok arányát, a Schwarzschild lencsézéssel összehasonlítva. A legfeltûnőbb módosulás a fluxusok arányában jelenik meg. Amikor az árapálytöltés képviseli a domináns lencséző hatást, a képek száma és az optikai tengelyhez viszonyított helyzete hasonlít a Schwarzschild geometria lencsézési sajátosságaira. Azonban a tömeg előjele ellentétes szerepet játszik, mint az árapálytöltés előjele. 


\subsubsection{A lencseegyenlet}

A lencseegyenlet levezetése a 2.2 ábrák alapján történik, trigonometria felhasználásával. Az $\widehat{A S I}$ szög $\pi / 2+|\theta|-\delta$. Ezért az ASI háromszögben a szinusz tétel

$$
\frac{\overline{N I}-s \overline{N S}}{\sin \delta}=\frac{\overline{O I}-\overline{O A}}{\cos (\delta-|\theta|)}
$$

Az $s=\operatorname{sgn} \theta$ előjel alkalmazásával az (a)-(c) konfigurációk sajátosságait vettuik figyelembe. Az egyenletet megszorozzuk $\sin \delta \cos (\delta-|\theta|) / \overline{O I}$-vel:

$$
\left(\frac{\overline{N I}}{\overline{O I}}-s \frac{\overline{N S}}{\overline{O I}}\right) \cos (\delta-|\theta|)=\left(1-\frac{\overline{O A}}{\overline{O I}}\right) \sin \delta .
$$

A bal oldalt átírjuk a $\sin |\theta|, \cos \theta, \tan \beta$ szögfüggvények kifejezéseivel, az $O N I$ és az $O N S$ háromszögek alapján. A jobb oldal második tagját az $\overline{O I}=D_{s} \cos \theta$ egyenlőség szerint írjuk át. A fénysugár $A$ töréspontját $\widehat{O A L}=\widehat{S A L}=(\pi-\delta) / 2$ definiálja. Ekkor $\widehat{O L A}=\pi / 2+$ $|\theta|+\delta / 2$, és a szinusz tétel a $L A O$ háromszögben

$$
\frac{\overline{O A}}{\cos \left(\frac{\delta}{2}-|\theta|\right)}=\frac{D_{l}}{\cos \frac{\delta}{2}}
$$

Ezért az (4.3) egyenlet a következóképpen írható:

$$
0=\frac{2 D_{l}}{D_{s}} \cos \left(\frac{\delta}{2}-|\theta|\right) \cos |\theta| \sin \frac{\delta}{2}+\cos (\delta-|\theta|)(\sin |\theta|-s \cos |\theta| \tan \beta)-\sin \delta .
$$

Az egyenlet levezetése során a szögfüggvényeket nem fejtettük sorba, ebben az értelemben ez egy egzakt lencseegyenlet.

Amikor $O, L$ és $S$ kollineáris, azaz $\beta=0$, a lencseegyenlet egyszerúsödik:

$$
0=D_{l} \sin |\theta|+D_{l s} \sin (|\theta|-\delta)
$$

Ennek megoldása az Einstein gyưrú sugara:

$$
|\theta|=\arctan \frac{D_{l s} \sin \delta}{D_{l}+D_{l s} \cos \delta} .
$$

Egy megfelelôen definiált határesetben a (4.5) lencseegyenlet a Virbhadra-Ellis lencseegyenletre egyszerúsödik. Ehhez feltesszük, hogy $\overline{L A} \perp \overline{O N}$. A feltevés hibát hoz be, amelynek rendje a merôlegességtôl való $\theta-\delta / 2$ eltérés nagyságrendje. Ebben az $\epsilon:=\delta-2|\theta|$ paraméterben elsô rendig a (4.5) egyenlet

$$
\begin{aligned}
0= & \tan |\theta|-s \tan \beta-\frac{D_{l s}}{D_{s}} \tan |\theta|-\frac{D_{l s}}{D_{s}} \tan (\delta-|\theta|) \\
& +\epsilon \tan |\theta|\left(s \tan \beta+\frac{D_{l s}}{D_{s}} \tan |\theta|\right)+\mathcal{O}\left(\epsilon^{2}\right) .
\end{aligned}
$$

A tan $(\delta-|\theta|)$ tag sorában az első rendú járulék $\epsilon / \cos ^{2}|\theta|$. Az utolsó tag elsố rendú közelítését úgy kapjuk, hogy kicseréljük $\beta$-t nulladrendú közelítésével, $s \tan \beta=\tan |\theta|-2\left(D_{l s} / D_{s}\right) \tan |\theta|$, így $\epsilon\left(D_{l} / D_{s}\right) \tan ^{2}|\theta|$-t kapunk. Ha $|\theta|$ kis szög, ezt a járulék elhanyagolható az $\epsilon / \cos ^{2}|\theta|$ taghoz képest. A megmaradó tagok a Virbhadra-Ellis lencseegyenletet adják:

$$
0=\tan |\theta|-\tan (s \beta)-\frac{D_{l s}}{D_{s}}[\tan |\theta|+\tan (\delta-|\theta|)]
$$


A (4.8) egyenlet kis látszó szögekre, $\delta-2|\theta|$ rendú hibával érvényes. Az $\epsilon$ mennyiség 0 ha $O, L$ és $S$ kollineáris $(\beta=0)$ és az $S, O$ pontok helyzete szimmetrikus $L$-hez képest. Tehát az várható, hogy a (4.5) és a (4.8) lencseegyenletek elôrejelzései annál inkább eltérnek egymástól, minél aszimmetrikusabb az $\mathrm{S}$ és $\mathrm{O}$ elhelyezkedése L-hez képest.

Adott $\beta$ forrás helyzethez a képek helyzetét a lencseegyenletből és a $\delta$ elhajlási szög képletéből álló egyenletrendszer megoldásával lehet kiszámolni.

\subsubsection{A tömeg és árapálytöltés paraméterben másodrendú lencseegyenlet}

A képek helyzetének megtalálásához először a (4.1) sort be kell helyettesíteni a (4.5) egyenletbe. Azután a gyenge lencsézés feltevésből következő közelítéseket el kell végezni.

Az alábbi alternatív paramétereket vezetjük be:

$$
\bar{\varepsilon}=\frac{m}{L}, \quad \bar{\eta}=\frac{q}{L^{2}},
$$

ahol $L=D_{l} D_{s} / D_{l s}$. A (4.5) egyenlet jobb oldalát sorfejtve, mindkét paraméterben másodrendú pontossággal

$$
0=L_{0}+\bar{\varepsilon} L_{10}+\bar{\eta} L_{01}+\bar{\varepsilon}^{2} L_{20}+\bar{\varepsilon} \bar{\eta} L_{11}+\bar{\eta}^{2} L_{02}
$$

adódik. Az együtthatók

$$
\begin{aligned}
L_{0} & =\cos ^{2} \theta(\tan |\theta|-s \tan \beta), \\
L_{10} & =-4 \cos |\theta|\left(s \frac{L}{D_{l}} \tan \beta+\cot |\theta|\right), \\
L_{01} & =\frac{3 \pi}{4} \frac{L}{D_{l}} \cot |\theta|\left(s \frac{L}{D_{l}} \tan \beta+\cot |\theta|\right), \\
L_{20} & =\frac{L}{4 D_{l}} \cot |\theta|\left[s \frac{L}{D_{l}} \tan \beta(32 \cot |\theta|-15 \pi)-32-15 \pi \cot |\theta|\right], \\
L_{11} & =-\frac{L^{2}}{D_{l}^{2}} \frac{\cos |\theta|}{\sin ^{2}|\theta|}\left[s \frac{L}{D_{l}} \tan \beta(3 \pi \cot |\theta|-16)-3 \pi-16 \cot |\theta|\right], \\
L_{02} & =\frac{3 \pi}{64} \frac{L^{3}}{D_{l}^{3}} \frac{\cos |\theta|}{\sin ^{3}|\theta|}\left[s \frac{L}{D_{l}} \tan \beta(6 \pi \cot |\theta|-35)-6 \pi-35 \cot |\theta|\right] .
\end{aligned}
$$

Az $L_{0}$ nulladrendû együtthatóból látszik, hogy a fekete lyuk hiányában $(m=0=q)$ nincs elhajlás $(\theta=\beta)$.

A Schwarzschild lencsézés esetét a (4.10) egyenletből az $\bar{\eta}=0$ feltétellel, az $\bar{\varepsilon}$-ban az első rendet megtartva kapjuk:

$$
0=\cos |\theta|\left[\cos |\theta|(\tan |\theta|-s \tan \beta)-4 \bar{\varepsilon}\left(\cot |\theta|+s \frac{L}{D_{l}} \tan \beta\right)\right] .
$$

A $\beta=\mathcal{O}(\theta)$ és $\bar{\varepsilon}=\mathcal{O}\left(\theta^{2}\right)$ feltevésekkel, a $\beta$ és $\theta$ szögekben újabb sorfejtést végezve a Schwarzschild lencseegyenlet adódik

$$
0=\theta^{2}-\beta \theta-4 \bar{\varepsilon} \equiv \mathcal{S} .
$$

Ha $O, L$ és $S$ egyaránt az optikai tengelyen helyezkedik el, akkor a megoldás az Einstein gyưrú sugara

$$
\theta_{E}=2 \bar{\varepsilon}^{1 / 2}
$$

Egy hipotetikus negatív tömegú Schwarzschild lencse szintén két képet hoz létre [96], feltéve hogy (4.13) diszkriminánsa pozitív. Ekkor azonban mindkét kép pozitív látszó szögú. A két kép egybeesik, ha a diszkrimináns 0 . A képek a 4.1 ábrán találhatók. 


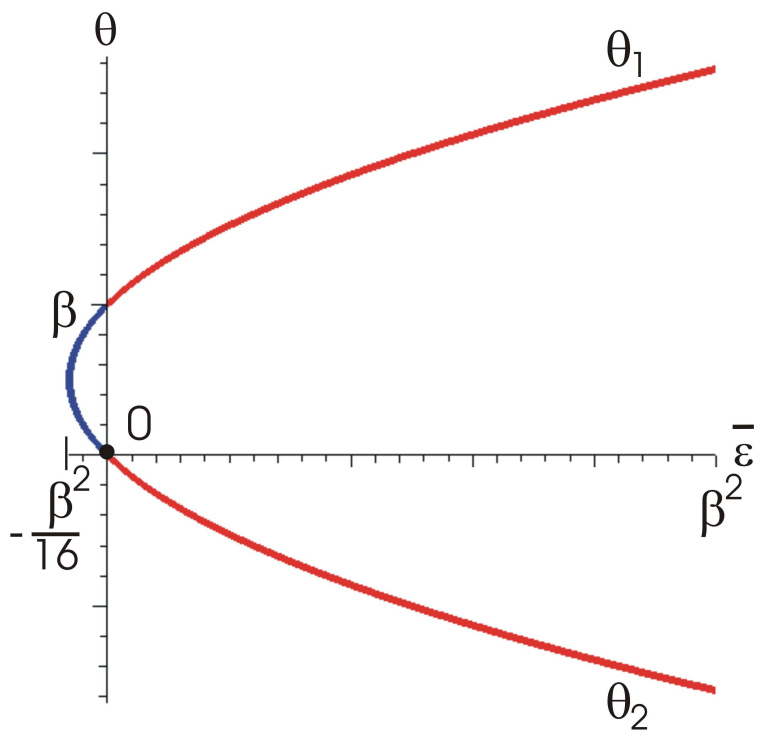

a.)

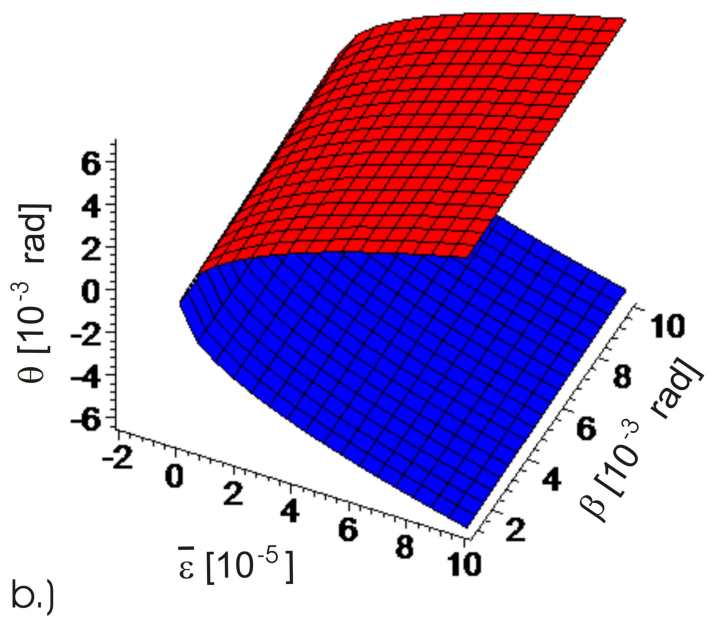

4.1. ábra. Ha a lencsézést a tömeg hatása dominálja az árapálytöltéssel szemben, akkor a képek hasonlóan keletkeznek, mint a Schwarzschild esetben. $\beta>0$ a forrás valódi helyzete. (a) A Schwarzschild fekete lyuk által keltett $\theta$ képek, $\beta$ egységben mérve. A lencsét az $\bar{\varepsilon}$ paraméterrel jellemezzük, $\beta^{2}$ egységben. Ha a tömeg pozitív $(\bar{\varepsilon}>0)$ akkor két kép keletkezik, egy-egy az optikai tengely felett és alatt. Ha $\bar{\varepsilon}<0$ akkor mindkét kép az optikai tengely felett található. Az $\bar{\varepsilon}=-\beta^{2} / 16$ tömeg értéknél a képek egybeesnek. Tetszőleges $\beta-$ ra, a nagy negatív tömegekre ( $\left.\bar{\varepsilon}<-\beta^{2} / 16\right)$ nem jöhet létre kép. (b) $\theta$ az $\bar{\varepsilon}$ és $\beta$ függvényében. Ahogy $\beta$ csökken, a képek nagysága zsugorodik. A felület $\beta=0$ metszete szimmetrikus $\theta=0$ síkra, hiszen a metszet az Einstein gyưrű sugarakat tartalmazza. 


\subsubsection{Tömeg dominált gyenge lencsézés $\mathcal{O}\left(\bar{\varepsilon}^{2}\right)$ rendig}

Ha $\bar{\varepsilon}=\mathcal{O}\left(\theta^{2}\right)$ és $\bar{\eta}=\mathcal{O}\left(\theta^{4}\right)$ akkor az $\bar{\varepsilon} \bar{\eta}$ és $\bar{\eta}^{2}$ tagok eldobhatók a (4.10) lencseegyenletben. A megtartott $\mathcal{O}(\theta)$ és $\mathcal{O}\left(\theta^{2}\right)$ tagok a

$$
0=\frac{\mathcal{S}}{\theta}+s \gamma \frac{\bar{\eta}-5 \bar{\varepsilon}^{2}}{\theta^{2}}
$$

ill.

$$
0=\theta^{3}-\beta \theta^{2}-4 \bar{\varepsilon} \theta+s \gamma\left(\bar{\eta}-5 \bar{\varepsilon}^{2}\right)
$$

közelítő lencseegyenletet adják, ahol

$$
\gamma=\frac{3 \pi}{4} \frac{L}{D_{l}}>2.35
$$

Az (általánosabb) $\bar{\eta}=\mathcal{O}\left(\theta^{\geq 4}\right)$ feltevés mellett, a (4.16) egyenlet utolsó tagja perturbáció a Schwarzschild lencsézéshez képest. Ezért a megoldásokat

$$
\widetilde{\theta}=\theta_{1,2}[1+\mathcal{T}(\beta, \gamma, s, \bar{\varepsilon}, \bar{\eta})]
$$

alakban keressük. A $\theta_{1,2}$ Schwarzschild képek korrekciói tehát $\mathcal{T}_{1} \theta_{1}, \mathcal{T}_{2} \theta_{2}$. A megoldások

$$
\mathcal{T}_{1,2}=\frac{s_{1,2} \gamma\left(\bar{\eta}-5 \bar{\varepsilon}^{2}\right)}{\theta_{1,2}\left(-3 \theta_{1,2}^{2}+2 \beta \theta_{1,2}+4 \bar{\varepsilon}\right)} .
$$

(A pozitív és negatív képek indexeit és előjeleit az $s_{1}=\operatorname{sgn} \theta_{1}=+1, s_{2}=\operatorname{sgn} \theta_{2}=-1$ megállapodással társítottuk össze.) Két kép keletkezik, melyek helyzete

$$
\begin{aligned}
\widetilde{\theta}_{1,2} & =\theta_{1,2} \mp \mathcal{A}_{1,2} \\
\mathcal{A}_{1,2} & \equiv-s_{1,2} \theta_{1,2} \mathcal{T}_{1,2}=\frac{\gamma\left(\bar{\eta}-5 \bar{\varepsilon}^{2}\right)}{\beta \theta_{1,2}+8 \bar{\varepsilon}}
\end{aligned}
$$

Az (4.21) korrekció első alakjából a Reissner-Nordström fekete lyuk lencsézését bemutató [75] cikk (21) képlete előállítható: az átalakítás az $x^{ \pm}=\widetilde{\theta}_{1,2} / \theta_{E}, x_{0}^{ \pm}=\theta_{1,2} / \theta_{E}, y=\beta / \theta_{E}$, $d_{R N}=\gamma(5 \bar{\varepsilon}-\bar{\eta} / \bar{\varepsilon}) / 4 \theta_{E}$ jelölés cserékkel lehetséges (az említett képlet bal oldalán található ${ }_{1}$ index egy elírás). Eredményünk azonban általánosabb, hiszen negatív árapálytöltésre is érvényes, aminek nincs megfelelője az ÁRE-ben. Az $\mathcal{A}_{1,2}$ második alakját úgy kapjuk, hogy a $\theta_{1,2}$ szögben négyzetes tagot kiküszöböljük a (4.19) megoldásból a (4.13) Schwarzschild lencseegyenlet segítségével.

A $\beta=0$ kollineáris esetben megjelenő Einstein gyưrű sugara

$$
\widetilde{\theta}_{E}=\theta_{E}-\frac{\gamma}{8}\left(\frac{\bar{\eta}}{\bar{\varepsilon}}-5 \bar{\varepsilon}\right)
$$

A (4.18) feltevést igazolja, hogy a (4.21) és a (4.22) második tagja a $\theta_{1,2}$ Schwarzschild képekhez képest egy renddel kisebb, azaz $\mathcal{O}\left(\theta^{2}\right)$ rendú korrekciók.

\section{Nagyítások}

A (2.39) Schwarzschild nagyítások korrekcióit úgy határozzuk meg, hogy kiszámoljuk a (2.38) determináns reciprokát a (4.20) képek ismeretében.

$$
\widetilde{\mu}_{1,2}=\mu_{1,2}\left(1 \mp \frac{\mathcal{A}_{1,2}}{\theta_{1,2}} \frac{8 \bar{\varepsilon} \pm \beta \mathcal{A}_{1,2}}{8 \bar{\varepsilon}+\beta \theta_{1,2}}\right) \pm \frac{\theta_{1,2}}{\beta} \frac{\mathcal{A}_{1,2}\left(\theta_{1,2} \mp \mathcal{A}_{1,2}\right)}{\beta \theta_{1,2}+8 \bar{\varepsilon}} .
$$




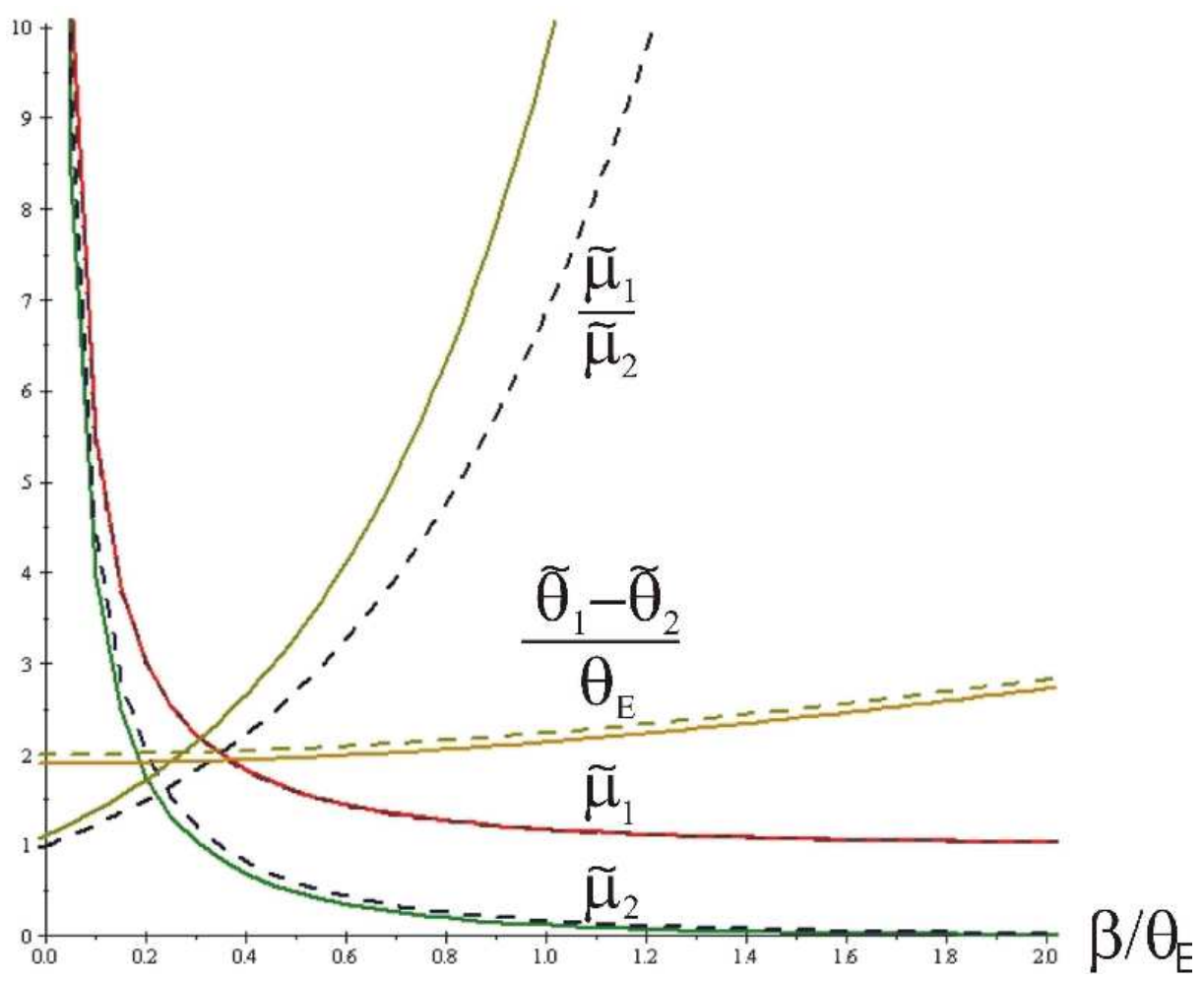

4.2. ábra. A képek távolsága, nagyításai és a nagyítások aránya a $\beta / \theta_{E}$ normált forrás helyzet függvényében. A perturbált esetet folytonos vonallal, a Schwarzschild esetet szaggatott vonallal ábrázoljuk. A paramétereket úgy rögzítjük, hogy $\gamma\left(\bar{\eta}-5 \bar{\varepsilon}^{2}\right)=10^{-1} \theta_{E}^{3}$, így $\bar{\eta}-5 \bar{\varepsilon}^{2}>0$. A $\beta / \theta_{E}=0.8$ értéknél a görbék felülről lefelé haladva: a fluxusok aránya $\widetilde{\mu}_{1} / \widetilde{\mu}_{2}$, a kép távolság $\left.\widetilde{(}_{1}-\widetilde{\theta}_{2}\right) / \theta_{E}$, a pozitív kép $\widetilde{\mu}_{1}$ nagyítása, a negatív kép $\widetilde{\mu}_{2}$ nagyítása.

A kifejezés $\mathcal{O}(\theta)$ rendû része $\left(\bar{\varepsilon}=\theta_{E}^{2} / 4\right.$ felhasználásával, 1. (4.14))

$$
\widetilde{\mu}_{1,2}=\mu_{1,2}\left(1 \mp \frac{2 \theta_{E}^{2} \mathcal{A}_{1,2}}{\left(2 \theta_{E}^{2}+\beta \theta_{1,2}\right) \theta_{1,2}}\right) \pm \frac{\mathcal{A}_{1,2} \theta_{1,2}^{2}}{\beta\left(2 \theta_{E}^{2}+\beta \theta_{1,2}\right)} .
$$

Az 4.2 ábrán a képek szögtávolsága, nagyításai és utóbbiak aránya látható a perturbált és Schwarzschild esetekben (a Schwarzschild esetre vonatkozó ábrát 1. még [5] 2.4 ábra.)

Ha $\bar{\eta}-5 \bar{\varepsilon}^{2}>0$, akkor a képek távolsága a perturbált esetben kisebb, mint a Schwarzschild lencsézésnél. A pozitív kép nagyítása elhanyagolható mértékben perturbálódik. A negatív kép nagyítása kisebb a perturbált esetben. A $\mu_{1} / \mu_{2}$ és $\tilde{\mu}_{1} / \tilde{\mu}_{2}$ fluxusok aránya egyre jobban különböznek ahogy $\beta$ nő, az arány a perturbált esetben nagyobb. A megfigyelések szempontjából ennek mérése a legalkalmasabb a kétféle fekete lyuk megkülönböztetésére.

Ha $\bar{\eta}-5 \bar{\varepsilon}^{2}<0$, akkor az említett eltérések ellentétes előjelúek. A képek távolsága és a negatív kép nagyítása nagyobb lesz, a fluxusok aránya kisebb.

\subsection{4. Árapálytöltés dominált gyenge lencsézés $\mathcal{O}(\bar{\eta})$ rendig}

Ha $\bar{\eta}=\mathcal{O}\left(\theta^{3}\right)$ akkor a (4.10) lencseegyenlet $\mathcal{O}(\bar{\eta})$ rendig

$$
0=\cos ^{2} \theta(\tan |\theta|-s \tan \beta)+\bar{\eta} \frac{3 \pi}{4} \frac{L}{D_{l}} \cot |\theta|\left(\cot |\theta|+s \frac{L}{D_{l}} \tan \beta\right) .
$$

A $\theta$ és $\beta$ változókban sorfejtést végezve a

$$
0=\theta^{3}-\beta \theta^{2}+s \gamma \bar{\eta}
$$


közelítő lencseegyenletet kapjuk. Ebben a közelítésben tehát a lencsézés nem függ a tömegtől.

A harmadfokú polinom valós gyökeit keressük. A polinom diszkriminánsa

$$
\Delta=s \bar{\eta} \gamma\left(-\frac{\beta^{3}}{27}+\frac{s \bar{\eta} \gamma}{4}\right)
$$

Egy valós gyök létezik amikor $\Delta>0$, azaz $s \bar{\eta}<0$ vagy $s \bar{\eta}>4 \beta^{3} / 27 \gamma$. Az ellenkező esetben, amikor $0<s \bar{\eta} \leq 4 \beta^{3} / 27 \gamma$, három valós gyök van (közülük kettő egybeesik, ha $s \bar{\eta}=4 \beta^{3} / 27 \gamma$ ). Az $s \bar{\eta}=0$ esetben nem történik elhajlás. Az Einstein gyưrú keletkezését a 4.1.4 szakaszban tárgyaljuk, addig legyen $\beta \neq 0$. Három esetet kell elemezni.

\section{$s \bar{\eta}<0$ tartomány}

A (4.26) polinom egyetlen valós gyöke

$$
\begin{aligned}
\theta_{\eta 1} & =\frac{\beta}{3}+\frac{2 \beta}{3} \cosh \omega_{1}>\beta, \\
\omega_{s} & =\frac{1}{3} \operatorname{arc} \cosh \left(s-\frac{27}{2} \frac{\gamma \bar{\eta}}{\beta^{3}}\right),
\end{aligned}
$$

ami akkor és csak akkor egy kép látszószöge, ha sgn $\theta_{\eta 1} \equiv s=-\operatorname{sgn} \bar{\eta}$ teljesül. Mivel sgn $\theta_{\eta 1}=+1$, a képet negatív árapálytöltésú lencse hozza létre. A lencsézési konfiguráció a 2.2 ábrán található (a) típus, tehát a negatív árapálytöltés hatása hasonló a (pozitív) tömegéhez. A $\theta_{\eta 1}$ kép negatív párját, $\theta_{\eta 2}$-t az $s \bar{\eta}>4 \beta^{3} / 27 \gamma$ eset elemzése során találjuk meg.

\section{$s \bar{\eta}>4 \beta^{3} / 27 \gamma$ tartomány}

Mivel $s \bar{\eta}>0$, ezért $\operatorname{sgn} \theta_{\eta 2}=s=\operatorname{sgn} \bar{\eta}$. A (4.26) polinom egyetlen valós gyöke

$$
\theta_{\eta 2}=\frac{\beta}{3}-\frac{2 \beta}{3} \cosh \omega_{-1} \leq-\frac{\beta}{3}
$$

tehát $s=-1$ és a képet negatív árapálytöltésú lencse hozza létre. Így $\theta_{\eta 2}$ a (4.28) kép párja.

\section{$0<s \bar{\eta} \leq 4 \beta^{3} / 27 \gamma$ tartomány}

A polinomokra vonatkozó előjelváltási szabály alapján páros számú pozitív gyököt várunk. Két pozitív gyök létezik:

$$
\begin{aligned}
& \theta_{\eta 2}^{\prime \prime}=\frac{\beta}{3}+\frac{2 \beta}{3} \cos \left(\varphi_{1}+\frac{2 \pi}{3}\right) \in(0, \beta) . \\
& \theta_{\eta 1}^{\prime \prime}=\frac{\beta}{3}+\frac{2 \beta}{3} \cos \left(\varphi_{1}-\frac{2 \pi}{3}\right) \in(0, \beta) . \\
& \varphi_{s}=\frac{1}{3} \arccos \left(1-\frac{27}{2} s \frac{\gamma \bar{\eta}}{\beta^{3}}\right)+\frac{2 \pi}{3} .
\end{aligned}
$$

Mindkét kép a 2.2b ábrának megfelelő szórt kép. Az $s \bar{\eta}>0$ feltevés miatt $\operatorname{sgn} \theta_{\eta 2}=s=\operatorname{sgn}$ $\bar{\eta}$, tehát ez a kép pozitív árapálytöltésú lencse jelenlétében jön létre. A $0<s \bar{\eta} \leq 4 \beta^{3} / 27 \gamma$ tartományban $\theta_{\eta 2}^{\prime \prime} \leq \theta_{\eta 1}^{\prime \prime}$, az $\bar{\eta}=4 \beta^{3} / 27 \gamma$ értéknél pedig $\theta_{\eta 1}^{\prime \prime}=\theta_{\eta 2}^{\prime \prime}=2 \beta / 3$. A polinom harmadik gyöke negatív:

$$
\theta_{\eta 2}^{\prime}=\frac{\beta}{3}+\frac{2 \beta}{3} \cos \varphi_{-1} \in\left[-\frac{\beta}{3}, 0\right),
$$

amelyet negatív árapálytöltésû́ lencse hoz létre. A $0<s \bar{\eta} \leq 4 \beta^{3} / 27 \gamma$ tartományban ez a kép a $\theta_{\eta 1}$ párja.

Az $\bar{\eta} \rightarrow 0$ határátmenetben a pozitív képek $\beta$-hoz tartanak, hiszen $\omega_{s} \rightarrow 0, \varphi \rightarrow 2 \pi / 3$. (A Schwarzschild lencsézésben az $\bar{\varepsilon} \rightarrow 0$ határátmenet viselkedik így.) 


\section{A képek helyzetének összefoglalása}

Az $\bar{\eta}$ árapálytöltés különböző tartományaiban a képek helyzetét az 4.3 ábra mutatja be. Az árapálytöltés előjelétôl függetlenül a képek száma kettő (kivéve a már említett $\bar{\eta}=4 \beta^{3} / 27 \gamma$ elfajult esetet, amikor a képek egybeesnek).

Negatív árapálytöltésû́ lencse esetén $\theta_{\eta 1}$ pozitív, és az árapálytöltés nagyságától függôen a negatív kép $\theta_{\eta 2}$ vagy $\theta_{\eta 2}^{\prime}$. (A $\cosh x=\cos i x$ azonosság révén megmutatható, hogy $\varphi=$ $\pi-i \omega_{-1}$. Ez azt jelenti, hogy $\theta_{\eta 2}$ és $\theta_{\eta 2}^{\prime}$ ugyanazt a komplex függvényt jelöli.)

Pozitív árapálytöltésú lencse esetén a $\theta_{\eta 1}^{\prime \prime}, \theta_{\eta 2}^{\prime \prime}$ szórt képek keletkeznek, a 2.2b ábrának megfelelően. A lehetőség, hogy több ilyen típusú fénysugár jöjjön létre, amely összeköti a forrást és megfigyelôt, onnan ered, hogy az elhajlás erôsödik ha az impakt paraméter megközelíti a lencsét. Ez a viselkedés analóg a negatív tömegû Schwarzschild lencse által keltett szórással [96]. Ugyancsak hasonló a lencsét jellemző fizikai paraméter felső határának létezése, amely a szórást lehetôvé tevő legnagyobb érték ( $\bar{\eta}_{\max }=4 \beta^{3} / 27$ a brán fekete lyuk esetében, $|\bar{\varepsilon}|_{\max }=\beta^{2} / 16 \mathrm{a}$ Schwarzschild lencsézésnél).

\section{Einstein gyúrú}

A $\beta=0$ esetben a (4.26) lencseegyenlet egyszerúsödik.

$$
0=|\theta|^{3}+\bar{\eta} \gamma
$$

Pozitív árapálytöltésre nincs megoldás. Negatív árapálytöltésre az Einstein gyưrű sugara $\theta_{\eta E}=$ $\gamma^{1 / 3}|\bar{\eta}|^{1 / 3}$. Ez az eredmény a $\theta_{\eta 1}, \theta_{\eta 2}$ és $\theta_{\eta 2}^{\prime}$ általános képletekből is megkapható, a $\beta \rightarrow 0$ határátmenetben, a l'Hospital szabály alkalmazásával: $\lim _{\beta \rightarrow 0} \theta_{\eta 1}=-\lim _{\beta \rightarrow 0} \theta_{\eta 2}=-\lim _{\beta \rightarrow 0} \theta_{\eta 2}^{\prime}=$ $\theta_{\eta E}$.

\section{Nagyítások}

Az (2.38) összefüggés alkalmazásával a fentiekben meghatározott $\theta_{\eta 1,2}, \theta_{\eta 2}^{\prime}, \theta_{\eta 1,2}^{\prime \prime}$ képekre az alábbi nagyítások számolhatók ki:

$$
\begin{aligned}
\mu_{\eta 1,2}= & \frac{2}{9} \sqrt{\frac{27 \theta_{\eta E}^{3}}{27 \theta_{\eta E}^{3} \mp 4 \beta^{3}}}\left(2 \cosh \omega_{ \pm 1} \pm 1\right) \sinh \omega_{ \pm 1}+\frac{\left(1 \pm 2 \cosh \omega_{ \pm 1}\right)^{2}}{9} \\
\mu_{\eta 2}^{\prime}= & \frac{-2}{9} \sqrt{\frac{-27 \theta_{\eta E}^{3}}{27 \theta_{\eta E}^{3}+4 \beta^{3}}}\left(2 \cos \varphi_{-1}+1\right) \sin \varphi_{-1}+\frac{\left(1+2 \cos \varphi_{-1}\right)^{2}}{9} \\
\mu_{\eta 1,2}^{\prime \prime}= & \pm \frac{2}{9} \sqrt{\frac{27 \theta_{\eta E}^{3}}{-27 \theta_{\eta E}^{3}+4 \beta^{3}}}\left[2 \cos \left(\varphi_{1} \mp \frac{2 \pi}{3}\right)+1\right] \sin \left(\varphi_{1} \mp \frac{2 \pi}{3}\right) \\
& \pm \frac{1}{9}\left[1+2 \cos \left(\varphi_{1} \mp \frac{2 \pi}{3}\right)\right]^{2} .
\end{aligned}
$$

A 4.4 ábrán a normált kép távolságok szerepelnek $\theta_{\eta E}$ egységekben, valamint a nagyítások és a fluxusok aránya, a $\beta / \theta_{\eta E}$ normált forrás helyzet függvényében, negatív árapálytöltés esetén. A $\theta_{\eta 1}$ kép akkor jön létre ha $\bar{\eta} \leq 0$. A $\theta_{\eta 2}$ kép akkor keletkezik, ha $\bar{\eta} \leq-4 \beta^{3} / 27 \gamma$ $\left(-\theta_{\eta E} \leq-4^{1 / 3} \beta / 3\right)$, így ekkor $\beta / \theta_{\eta E} \leq 3 / 4^{1 / 3}=1.8899$, míg a $\theta_{\eta 2}^{\prime}$ kép akkor jön létre, ha $-4 \beta^{3} / 27 \gamma \leq \bar{\eta} \leq 0\left(-4^{1 / 3} \beta / 3 \leq-\theta_{\eta E} \leq 0\right)$, azaz $\beta / \theta_{\eta E} \geq 3 / 4^{1 / 3}$. Ezért a $\left(\theta_{\eta 1}-\theta_{\eta 2}\right) / \theta_{\eta E}$, $\mu_{\eta 1}, \mu_{\eta 2}$, és $\mu_{\eta 1} / \mu_{\eta 2}$ mennyiségek az ábrán a $\beta / \theta_{\eta E} \in\left[0,3 / 4^{1 / 3}\right]$ tartományban találhatók, míg $\left(\theta_{\eta 1}-\theta_{\eta 2}^{\prime}\right) / \theta_{\eta E}, \mu_{\eta 1}, \mu_{\eta 2}^{\prime}$ és $\mu_{\eta 1} / \mu_{\eta 2}^{\prime}$ a $\beta / \theta_{\eta E} \geq 3 / 4^{1 / 3}$ tartományban. A Schwarzschild 
$\theta$

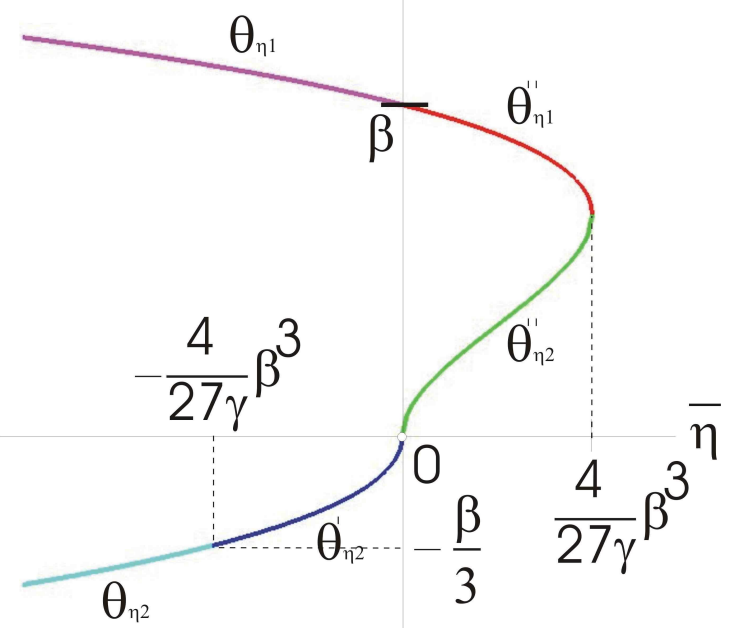

a.)

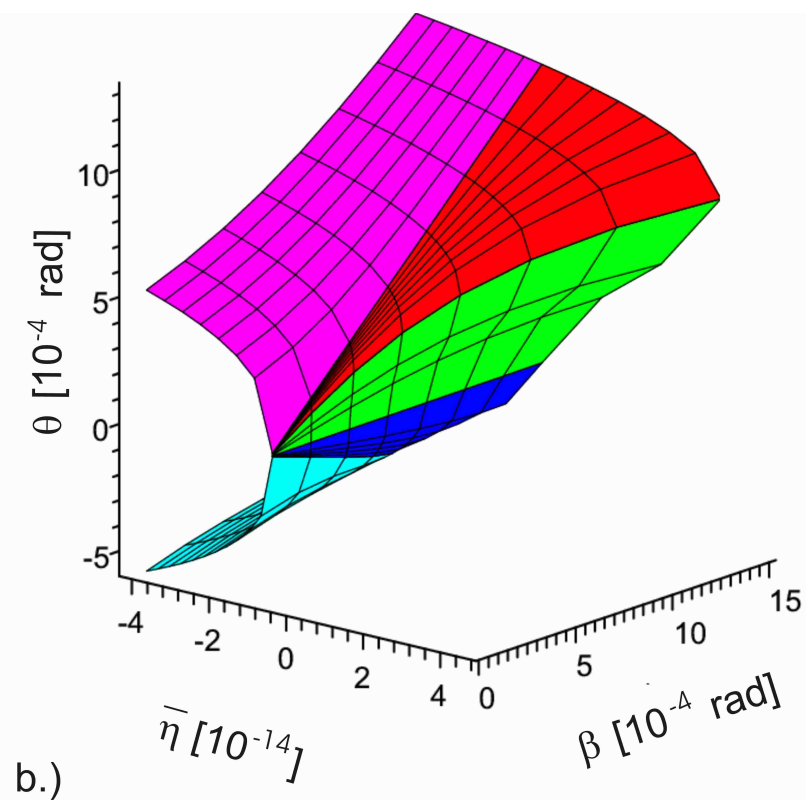

4.3. ábra. Amikor az árapálytöltés dominál, két kép keletkezik, de ezek különböznek a Schwarzschild esettől. (a) A képek $\theta$ helyzete az $\bar{\eta}$ paraméter függvényében. Ha $\bar{\eta}<0$, akkor egy-egy kép az optikai tengely felett és alatt jön létre. Ha $\bar{\eta}>0$, akkor mindkét kép az optikai tengely felett található. A képek egybeesnek ha $\bar{\eta}=4 \beta^{3} / 27 \gamma$. Ha $\bar{\eta}>4 \beta^{3} / 27 \gamma$, akkor egyáltalán nem jöhet létre kép. A színek a különböző képletekkel megadott képeket különböztetik meg, ezek a függvények egyetlen görbévé kapcsolódnak össze. (b) $\theta$ az $\bar{\eta}$ és a $\beta$ függvényében. Csökkenő $\beta$-ra a képek összemennek. A $\beta=0$ metszet az Einstein gyưrú sugarakat mutatja, ennek megfelelően szimmetrikus a $\theta=0$ síkra. 


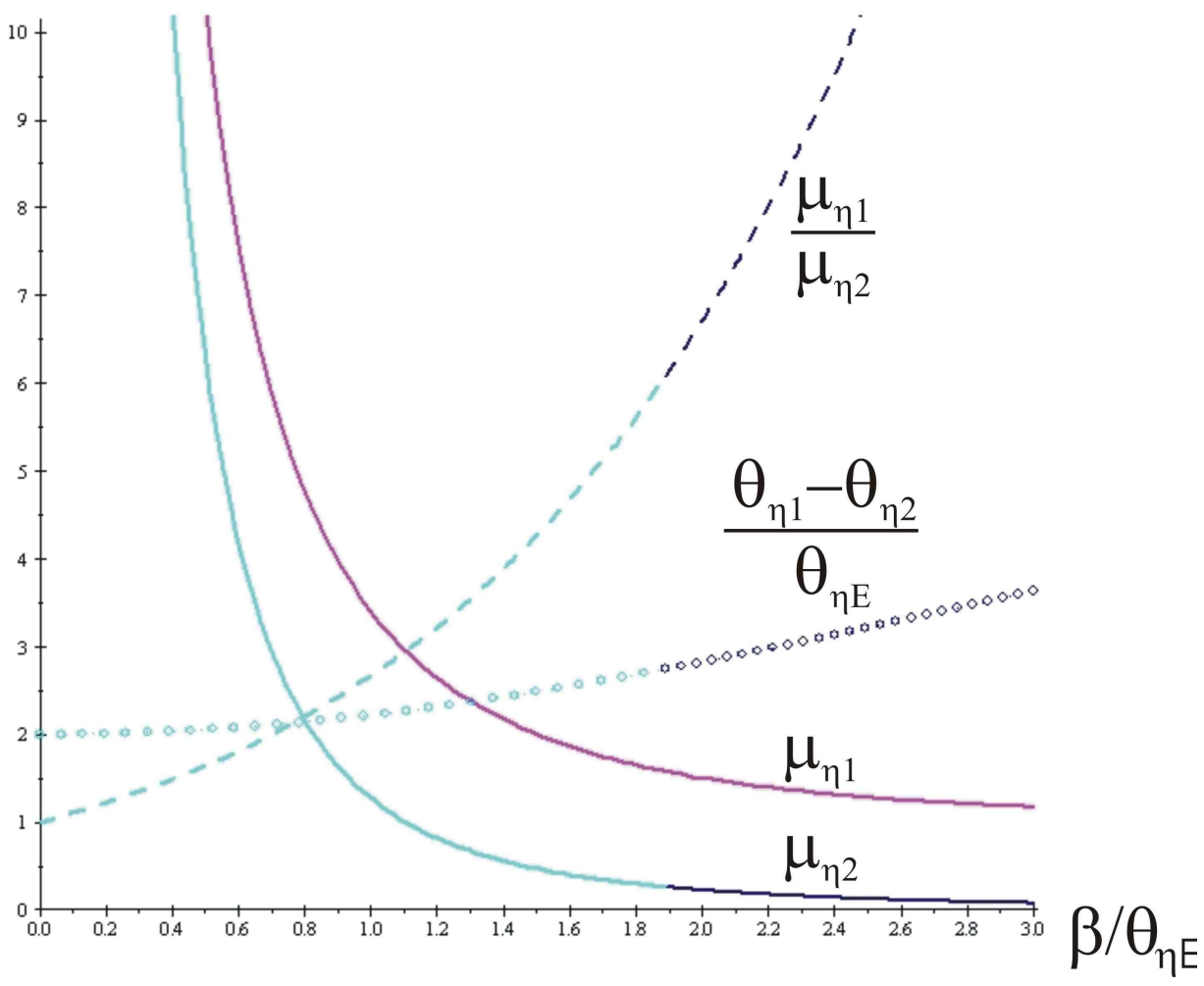

4.4. ábra. A képek távolsága és a nagyítások a negatív árapálytöltés által dominált fekete lyuk esetében, a $\beta / \theta_{\eta E}$ függvényében. A felső folytonos görbe a pozitív, az alsó a negatív kép nagyítása, arányuk a szaggatott görbe. A pontozott vonal a képek távolsága. A színek megváltozása a $\beta / \theta_{\eta E}=3 / 4^{1 / 3}$ értéknél a baloldali $\theta_{\eta 2}$ és a jobboldali $\theta_{\eta 2}^{\prime}$ függvények közötti átmenetre utal. 


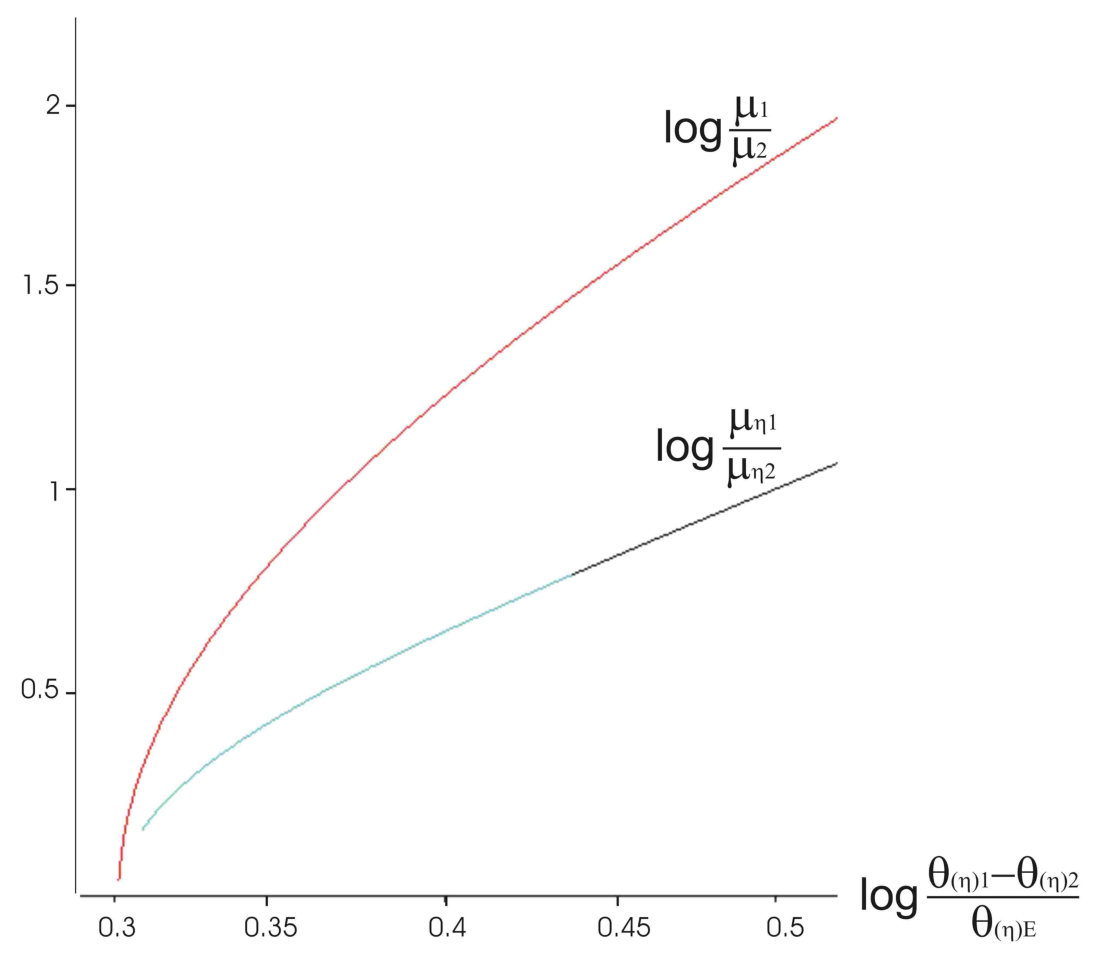

4.5. ábra. A nagyítások aránya a normált szögtávolság függvényében, log-log skálán, az árapálytöltés dominált lencse (jelölve az $\eta$ indexszel) és a Schwarzschild fekete lyuk esetében.

lencsézéshez hasonlóan, a képek szögtávolsága és a fluxusok aránya a forrás helyzetének szigorúan növekvő függvénye, míg a nagyítási tényezők csökkennek. A $\beta=0$ érték felé közeledve a nagyítások korlátlanul nőnek. A fluxusok aránya azonban 1-hez konvergál, amikor $\beta \rightarrow 0$.

A 4.5 ábra a nagyítások arányának logaritmusát ábrázolja az Einstein szöggel normált kép távolság logaritmusának függvényében. Ha a képek távolsága meghaladja az Einstein szög kb. 2.5-szörösét, akkor a fluxusok aránya hatványtörvénynek engedelmeskedik. Ebben a szögtávolság tartományban tehát

$$
\frac{\mu_{1}}{\mu_{2}} \propto\left(\frac{\Delta \theta}{\theta_{E}}\right)^{\kappa}
$$

érvényes. A 4.5 ábrán szereplő karakterisztikák alapján a Schwarzschild téridőben $\kappa=6.22 \pm$ .15, míg a (3.3) téridőben $\kappa_{\eta}=2.85 \pm .25$. Általában a lencsét nem látjuk, így a látszó szögek sem mérhetôk külön-külön. A forrás fényességét sem ismerjük, így a nagyítások sem mérhetők külön-külön. Amennyiben azonban a képek szögtávolságát mérni tudjuk, akkor a nagyítások aránya és a képek szögtávolsága függvényszerú kapcsolatba hozható, amit a (4.39) törvénnyel össze tudunk vetni Tehát a képek fényességeinek és szögtávolságainak mérése lehetôvé teszi, hogy különbséget tegyünk a Schwarzschild téridő és a (3.3) téridő között.

A 4.6 ábrán a $\left(\theta_{\eta 1}^{\prime \prime}-\theta_{\eta 2}^{\prime \prime}\right) /(\gamma \bar{\eta})^{1 / 3}$ normált kép távolságok szerepelnek, a $\mu_{\eta 1,2}^{\prime \prime}$ nagyítások és a $\mu_{\eta 1}^{\prime \prime} / \mu_{\eta 2}^{\prime \prime}$ fluxusok aránya, $\beta /(\gamma \bar{\eta})^{1 / 3}$ függvényében, pozitív árapálytöltésú ill. negatív tömegú Schwarzschild lencse esetén. Mivel a megengedett pozitív árapálytöltés tartomány $0 \leq \bar{\eta} \leq 4 \beta^{3} / 27 \gamma$ (így $0 \leq(\gamma \bar{\eta})^{1 / 3} \leq 4^{1 / 3} \beta / 3$ ), a $\beta /(\gamma \bar{\eta})^{1 / 3}$ változó alulról korlátos, $\beta /(\gamma \bar{\eta})^{1 / 3} \geq 3 / 4^{1 / 3}$. 


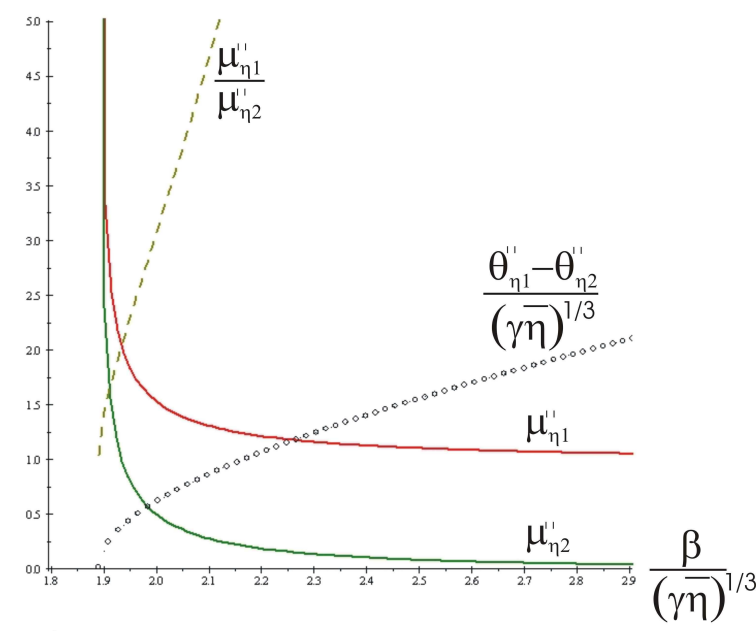

a.)

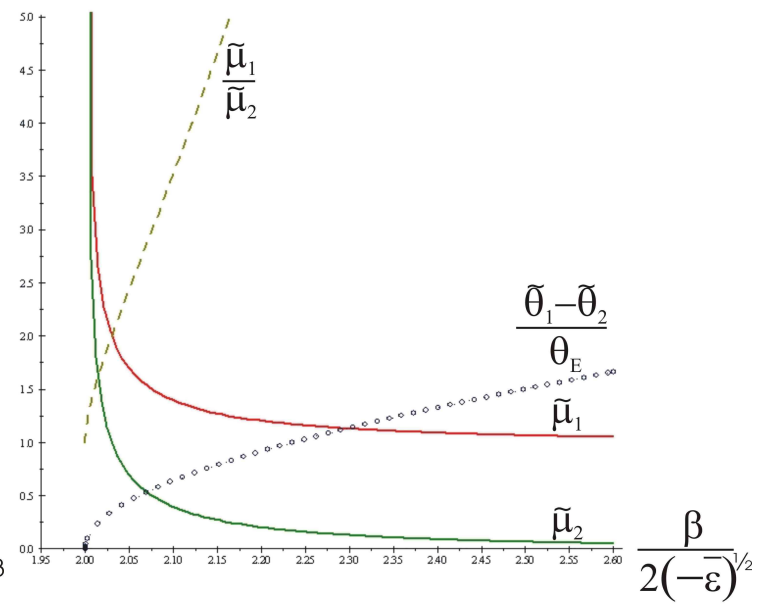

b.)

4.6. ábra. Az (a) ábrán a képek távolsága, nagyításai és a nagyítások aránya $\beta /(\gamma \bar{\eta})^{1 / 3}$ függvényében. A (b) ábrán a negatív tömegú Schwarzschild lencse hasonló jellemzối láthatók, $\beta / 2(-\bar{\varepsilon})^{1 / 2}$ függvényében.

\subsection{5. Árapálytöltés dominált gyenge lencsézés $\mathcal{O}\left(\bar{\eta}^{2}\right)$ rendig}

Ha $\bar{\eta}=\mathcal{O}\left(\theta^{3}\right)$ és $\bar{\varepsilon}=\mathcal{O}\left(\theta^{\geq 4}\right)$, akkor az $\bar{\varepsilon}^{2}$ és $\bar{\varepsilon} \bar{\eta}$ tagok eldobhatók a (4.10) lencseegyenletben, mert magasabb rendúek $\bar{\eta}^{2}$-nél. A (4.10) lencseegyenlet $\mathcal{O}\left(\bar{\eta}^{2}\right)$ rendig

$$
\begin{aligned}
0= & \cos ^{2} \theta(\tan \theta-\tan \beta)-4 \bar{\varepsilon} \cos \theta\left(\frac{4 \gamma}{3 \pi} \tan \beta+\cot \theta\right) \\
& +\gamma \bar{\eta} \cot \theta\left(s \cot \theta+\frac{4 \gamma}{3 \pi} \tan \beta\right) \\
& -\frac{\gamma^{3}}{9 \pi^{2}} \bar{\eta}^{2} \frac{\cos \theta}{\sin ^{3} \theta}\left[\frac{4 \gamma}{3 \pi} \tan \beta(6 \pi \cot \theta-35 s)-6 \pi-35 s \cot \theta\right] .
\end{aligned}
$$

A $\theta$ és $\beta$ változókban sorfejtést végezve a

$$
\begin{aligned}
0 & =\theta-\beta+\frac{s \gamma \bar{\eta}}{\theta^{2}}+\mathcal{U}(\bar{\varepsilon}, \bar{\eta}, s, \theta), \\
\mathcal{U} & =-\frac{35 s \gamma^{3}}{9 \pi^{2}} \frac{\bar{\eta}^{2}}{\theta^{4}}+\mathcal{U}_{3},
\end{aligned}
$$

közelítő lencseegyenletet kapjuk, ahol $\mathcal{U}_{3}$ az összes $\mathcal{O}\left(\theta^{3}\right)$ tagot tartalmazza:

$$
\mathcal{U}_{3}=-\frac{2 \theta+\beta}{3}(\theta-\beta)^{2}-\frac{4 \bar{\varepsilon}}{\theta} \frac{2 s \gamma \bar{\eta}}{3}+\frac{4 \gamma^{2} \beta \bar{\eta}}{3 s \pi \theta}-\frac{2 \gamma^{3} \bar{\eta}^{2}}{3 \pi \theta^{3}}+\frac{8 \gamma^{4} \beta \bar{\eta}^{2}}{9 \pi^{2} \theta^{4}}
$$

Az $\mathcal{U}_{3}$-ban lévő tagok $\mathcal{O}\left(\theta^{\geq 2}\right)$, így a (4.40) egyenletet a (4.26) egyenlet perturbációjának tekintjük. Ezért a megoldásokat

$$
\widetilde{\theta}=\theta\left[1+\mathcal{T}_{\eta}(\bar{\varepsilon}, \bar{\eta}, s, \beta)\right]
$$

alakban keressük.

Ha $\bar{\eta}$ pozitív, akkor jelöljük a (4.28), (4.30), (4.34) fókuszált képeket $\left(\theta_{\eta}\right)_{ \pm}$-szal. A fókuszált képek korrekciói

$$
\left(\mathcal{T}_{\eta}\right)_{ \pm}=\frac{\left(\theta_{\eta}\right)_{ \pm}^{2} \mathcal{U}_{2}\left(\bar{\varepsilon}, \bar{\eta}, s,\left(\theta_{\eta}\right)_{ \pm}\right)}{2 \gamma \bar{\eta}-s\left(\theta_{\eta}\right)_{ \pm}^{3}}
$$


a két kép helyzete $\left(\widetilde{\theta}_{\eta}\right)_{ \pm}=\left(\theta_{\eta}\right)_{ \pm}\left[1+\left(\mathcal{T}_{\eta}\right)_{ \pm}\right]$. Ha $\bar{\eta}$ negatív, akkor jelöljük a (4.31), (4.32) szórt képeket $\left(\theta_{\eta}\right)_{1,2}$-vel. A szórt képek korrekciói

$$
\left(\mathcal{T}_{\eta}\right)_{1.2}=\frac{\left(\theta_{\eta}\right)_{1,2}^{2} \mathcal{U}_{3}\left(\bar{\varepsilon}, \bar{\eta}, s,\left(\theta_{\eta}\right)_{1,2}\right)}{2 \gamma \bar{\eta}-s\left(\theta_{\eta}\right)_{1,2}^{3}}
$$

a képek helyzete $\left(\widetilde{\theta}_{\eta}\right)_{1,2}=\left(\theta_{\eta}\right)_{1,2}\left[1+\left(\mathcal{T}_{\eta}\right)_{1.2}\right]$. A $\left(\mathcal{T}_{\eta}\right)_{ \pm}$és $\left(\mathcal{T}_{\eta}\right)_{1.2}$ tagok rendje $\mathcal{O}(\theta)$, így a $\left(\theta_{\eta}\right)_{ \pm}\left(\mathcal{T}_{\eta}\right)_{ \pm}$és $\left(\theta_{\eta}\right)_{1,2}\left(\mathcal{T}_{\eta}\right)_{1.2}$ korrekciók valóban magasabb rendúek az előzô szakaszban kiszámolt látszó szögeknél.

\subsubsection{A (4.5) lencseegyenlet és a Virbhadra-Ellis lencseegyenlet összeha- sonlítása}

Az $\mathcal{U}_{3}$-ban szereplő tagok közül néhány eltér attól, amit a Virbhadra-Ellis egyenlet sorfejtéséből kapunk. Ebből az következik, hogy ezek a lencseegyenletek csak $\mathcal{O}\left(\theta^{2}\right)$ rendben egyeznek meg. Az $\bar{\varepsilon}=\mathcal{O}\left(\theta^{\geq 2}\right)$ és $\bar{\eta}=\mathcal{O}\left(\theta^{\geq 3}\right)$ minimális feltevések lefedik az eddig tárgyalt összes esetet. Ezzel a feltevéssel a (4.5) egyenlet általános kifejtését kapjuk, $\mathcal{O}\left(\theta^{4}\right)$ rendig:

$$
0=L_{0}^{H G H}+\bar{\varepsilon} L_{10}^{H G H}+\bar{\eta} L_{01}^{H G H}+\bar{\varepsilon}^{2} L_{20}^{H G E}+\bar{\varepsilon} \bar{\eta} L_{11}^{H G H}+\bar{\eta}^{2} L_{02}^{H G H},
$$

a következő együtthatókkal

$$
\begin{aligned}
L_{0}^{H G H} & =(\theta-\beta)\left[1-\frac{(2 \theta+\beta)(\theta-\beta)}{3}\right], \\
L_{10}^{H G H} & =-\frac{4}{\theta}+\frac{2}{3}\left(5 \theta-\frac{8 \gamma \beta}{\pi}\right), \\
L_{01}^{H G H} & =\frac{s \gamma}{\theta^{2}}-\frac{2 s \gamma}{3}\left(1-\frac{2 \gamma \beta}{\pi \theta}\right), \\
L_{20}^{H G E} & =-\frac{5 s \gamma}{\theta^{2}}-\frac{32 \gamma}{3 \pi \theta}\left(1-\frac{4 \gamma \beta}{3 \pi \theta}\right)+\frac{10 s \gamma}{3}\left(1-\frac{2 \gamma \beta}{\pi \theta}\right), \\
L_{11}^{H G H} & =\frac{256 \gamma^{2}}{9 \pi^{2} \theta^{3}}+\frac{16 s \gamma^{2}}{3 \pi \theta^{2}}\left(1-\frac{4 \gamma \beta}{3 \pi \theta}\right)-\frac{128 \gamma^{2}}{9 \pi^{2} \theta}\left(1-\frac{8 \gamma \beta}{3 \pi \theta}\right), \\
L_{02}^{H G H} & =-\frac{35 s \gamma^{3}}{9 \pi^{2} \theta^{4}}-\frac{2 \gamma^{3}}{3 \pi \theta^{3}}\left(1-\frac{4 \gamma \beta}{3 \pi \theta}\right)+\frac{35 s \gamma^{3}}{27 \pi^{2} \theta^{2}}\left(1-\frac{4 \gamma \beta}{\pi \theta}\right) .
\end{aligned}
$$

A hasonló sorfejtés a Virbhadra-Ellis egyenletre

$$
0=L_{0}^{V E}+\bar{\varepsilon} L_{10}^{V E}+\bar{\eta} L_{01}^{V E}+\bar{\varepsilon}^{2} L_{20}^{V E}+\bar{\varepsilon} \bar{\eta} L_{11}^{V E}+\bar{\eta}^{2} L_{02}^{V E} .
$$

Az együtthatók

$$
\begin{aligned}
L_{0}^{V E} & =(\theta-\beta)\left(1+\frac{\theta^{2}+\beta^{2}+\theta \beta}{3}\right), \\
L_{10}^{V E} & =-\frac{4}{\theta}-\frac{14 \theta}{3} \\
L_{01}^{V E} & =\frac{s \gamma}{\theta^{2}}+\frac{4 s \gamma}{3} \\
L_{20}^{V E} & =-\frac{5 s \gamma}{\theta^{2}}+\frac{64 \gamma}{3 \pi \theta}-\frac{20 s \gamma}{3}, \\
L_{11}^{V E} & =\frac{256 \gamma^{2}}{9 \pi^{2} \theta^{3}}-\frac{32 s \gamma^{2}}{3 \pi \theta^{2}}+\frac{128 \gamma^{2}}{3 \pi^{2} \theta}, \\
{ }^{2} L_{02}^{V E} & =-\frac{35 s \gamma^{3}}{9 \pi^{2} \theta^{4}}+\frac{4 \gamma^{3}}{3 \pi \theta^{3}}-\frac{175 s \gamma^{3}}{27 \pi^{2} \theta^{2}} .
\end{aligned}
$$




\subsection{Erôs gravitációs lencsézés árapálytöltésú fekete lyuk je- lenlétében}

Ebben az alfejezetben az az alapfeltevésünk, hogy a Galaxis magjában elhelyezkedő szupermasszív fekete lyuk olyan gravitációs lencse, amelyet a (3.3) metrika jellemez és nemnulla árapálytöltése van. A (3.3) fekete lyuk lencsézési tulajdonságait az árapálytöltése nem csak a gyenge lencsézés során módosítja a Schwarzschild lencséhez képest, hanem az erôs lencsézés során is. Még akkor is, ha a mérések a Schwarzschild lencse modellel megegyezó eredményt adnak, a mérőmúszer hibája megengedi, hogy a lencsének nemnulla árapálytöltése legyen.

A 4.7 ábrán látható 1-hurkos fotonpályákkal foglalkozunk, tehát az elsố relativisztikus Einstein gyưrű sugarát tanulmányozzuk. Ebből vezetünk le kényszert az árapálytöltésére.

Megfigyelési szempontból a Galaxis magja nehezen bontható fel. Ennek fô oka a források összeolvadása. A fényt elnyelő gáz és por miatt ismereteink nagyrészt rádió és infravörös megfigyelésekből származnak. A középpontban található szupermasszív fekete lyuk tömege $4.31 \times 10^{6} \mathrm{M}_{\odot}$, távolsága 8330 parsec $(\mathrm{pc})$. A legbelső 0.01 pc sugarú tartományban kb. 1000 naptömeg $\left(\mathrm{M}_{\odot}\right)$ hideg sötét anyag és $1000 \mathrm{M}_{\odot}$ kompakt csillagmaradvány található. A 0.04 pc sugarú tartomány a Sgr A* csillaghalmaz, amely B típusú csillagokból áll. A [0.04 pc, 0.5 pc] távolság tartományban Wolf Rayet és OB óriás csillagok találhatók. A fekete lyuk forog, perdülete és tömege hatással van a környezô csillagok mozgására. Ezeket a paramétereket a csillagok pályájának megfigyeléséből [76], [77] meg lehet határozni [78], [79].

A fekete lyuk és környezete megfigyelésére alkalmas lesz a GRAVITY interferométer, amelynek terveit a [80] publikáció tartalmazza. A tervek szerint a GRAVITY a Very Large Telescope négy távcsövét interferométerként fogja használni, a közeli infravörös tartományban. A tudományos célok között szerepel többek között a fekete lyuk körüli csillagok pályájának megfigyelése [80]. Az interferométer asztrometriai pontossága 12 mikroívmásodperc ( $\mu$ as) a K sávban 15 magnitúdóig:

$$
\Delta \Theta:=12 \times 10^{-6} \text { as. }
$$

A [81] cikkben a gyenge lencsézést végző szupermasszív fekete lyukról felteszik, hogy árapálytöltése van. A képek helyzete és nagyítása a töltés csökkenő függvényének bizonyult. A [72] cikkben erős lencsézést tanulmányoztak. Meghatározták azt a szögsugarat, ahol a második és magasabbrendû́ relativisztikus képek összeolvadnak. Ezeknek a képeknek a szögtávolságát az elsổ relativisztikus képtôl szintén megadták. A [82] cikkben az elsô és második relativisztikus Einstein gyưrú sugarát és nagyítását határozták meg. A fekete lyuk körül keringô S2, S6, S14 csillagok elsố relativisztikus képét a [83] cikk elemzi.

\subsubsection{Null geodetikusok és relativisztikus Einstein gyúrúk gömbszimmet- rikus, sztatikus téridốben}

A gömbszimmetrikus, sztatikus téridő általános alakja

$$
d s^{2}=g_{t t} d t^{2}+g_{r r} d r^{2}+g_{\theta \theta} d \theta^{2}+g_{\varphi \varphi} d \varphi^{2} .
$$

A továbbiakban $g_{\theta \theta}=r^{2}, g_{\varphi \varphi}=r^{2} \sin ^{2} \theta$. A mozgásokat a $\theta=\pi / 2$ egyenlítői síkban tanulmányozzuk. A másodrendú radiális geodetikus egyenletet kicseréljük az elsô rendú null feltételre

$$
0=g_{t t}\left(\frac{d t}{d p}\right)^{2}+g_{r r}\left(\frac{d r}{d p}\right)^{2}+g_{\varphi \varphi}\left(\frac{d \varphi}{d p}\right)^{2},
$$

ahol $p$ a görbe paramétere. Mivel a metrika nem függ a $t$ és $\varphi$ koordinátáktól, a geodetikus egyenletek két mozgásállandót adnak: az $L=g_{\varphi \varphi} d \varphi / d p$ fajlagos impulzusmomentumot $\left[\right.$ hossz $z^{2}$; és az $E=g_{t t} d t / d p$ fajlagos energiát [hossz ${ }^{2}$ ]. 

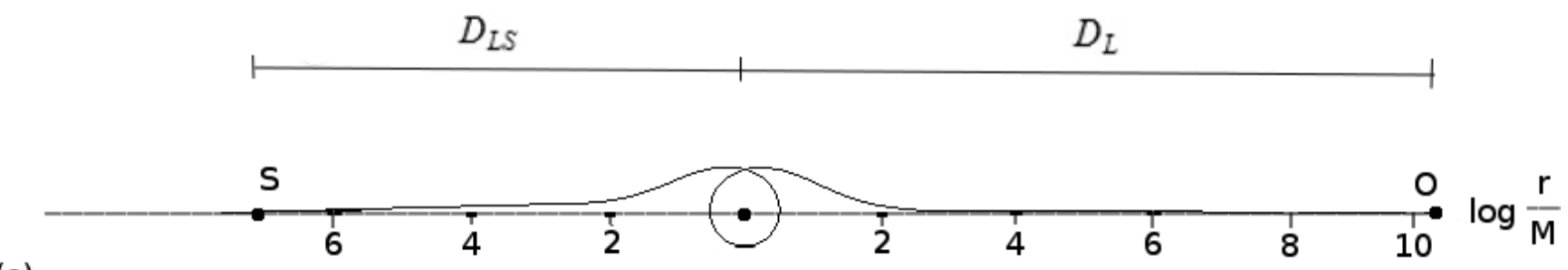

(a)

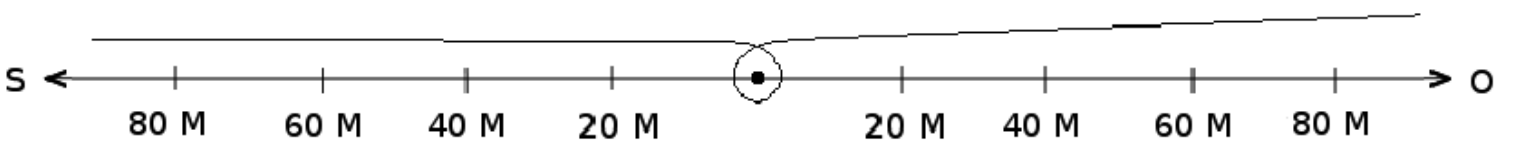

(b)

4.7. ábra. A foton pályája az $S$ forrástól az $O$ megfigyelőig, miközben egyszer megkerüli az $L$ lencsét, a $q=0, D_{\mathrm{L}}=8600 \mathrm{pc}, D_{\mathrm{LS}}=10 \mathrm{pc}$ választások mellett. Az (a) ábrán a teljes geodetikus látható logaritmikus skálán. A (b) ábrán a hurok és környezetének nagyítása látható lineáris skálán.

A null feltételben az $r r$ tag $g_{r r}(d r / d \varphi)^{2} \times L^{2} / g_{\varphi \varphi}^{2}$, a $t t$ és $\varphi \varphi$ tagok $E^{2} / g_{t t}$ és $L^{2} / g_{\varphi \varphi}$, tehát

$$
0=\frac{E^{2}}{g_{t t}}+g_{r r}\left(\frac{d r}{d \varphi}\right)^{2} \frac{L^{2}}{g_{\varphi \varphi}^{2}}+\frac{L^{2}}{g_{\varphi \varphi}} .
$$

Az egyenletet átrendezve a foton pálya alak egyenletét kapjuk:

$$
\frac{d r}{d \varphi}= \pm\left[\frac{g_{\varphi \varphi}}{g_{r r}}\left(\frac{E^{2}}{L^{2}} \frac{g_{\varphi \varphi}}{-g_{t t}}-1\right)\right]^{1 / 2}
$$

A \pm előjel az $r(\varphi)$ pálya bejövő és kimenő szakaszát különbözteti meg.

Olyan null geodetikus görbét keresünk, amelyen a foton az $S$ forrástól az $O$ megfigyelôiig halad, miközben egyszer megkerüli az $L$ lencsét (4.7 ábra).

A forrás, a lencse és a megfigyelő az optikai tengelyen helyezkedik el, $L$ az origóban van, $\mathrm{S}$ a $\left(\varphi=0, r=D_{\mathrm{LS}}\right), O$ a $\left(\varphi=\pi, r=D_{\mathrm{L}}\right)$ pontokban. Az $r(\varphi)$ pálya csökkenó függvény $r=$ $D_{\mathrm{LS}}$-tôl egy adott $r=r_{\min }$ távolságig, azután növekvő $r=D_{\mathrm{L}}$-ig. A minimális megközelítés távolságát a

$$
\frac{d r}{d \varphi}\left(\varphi_{\min }\right)=0
$$

egyenlet definiálja. A keresett 1-hurkos pályán a $\varphi$ polárszög teljes megváltozása S-tôl O-ig $\pi+2 \pi$.

A továbbiakban az $R=r / m$ dimenziótlan koordinátával dolgozunk. A keletkező képet elsô relativisztikus Einstein gyưrűnek nevezzük, ennek sugara az elsô relativisztikus Einstein szög $\Theta_{\mathrm{E}}$. A $\Theta_{\mathrm{E}}$ szög definíció szerint az SO optikai tengely és az $R(\varphi)$ geodetikus görbe $\partial / \partial p$ érintőjének szöge az $\mathrm{O}$ pontban. $\Theta_{\mathrm{E}}$-re képlet vezethetô le abból kiindulva, hogy $\partial / \partial R$ vektor (az optikai tengely iránya O-ban) és a $\partial / \partial p$ érintő belső szorzata kétféleképpen számolható ki. A belső szorzás definíciója alapján

$$
\frac{\partial}{\partial R} \cdot \frac{\partial}{\partial p}=\left|\frac{\partial}{\partial R}\right|\left|\frac{\partial}{\partial p}\right| \cos \Theta_{\mathrm{E}}=\sqrt{g_{R R}} \sqrt{\left(\frac{\partial R}{\partial p}\right)^{2} g_{R R}+\left(\frac{\partial \varphi}{\partial p}\right)^{2} g_{\varphi \varphi}} \cos \Theta_{\mathrm{E}} .
$$

Az érintő felbontása a polár koordináta rendszerben

$$
\frac{\partial}{\partial R} \cdot \frac{\partial}{\partial p}=\frac{\partial}{\partial R} \cdot\left(\frac{\partial R}{\partial p} \frac{\partial}{\partial R}+\frac{\partial \varphi}{\partial p} \frac{\partial}{\partial \varphi}\right)=\frac{\partial R}{\partial p} \frac{\partial}{\partial R} \cdot \frac{\partial}{\partial R}=\frac{\partial R}{\partial p} g_{R R}
$$


A jobb oldalak egyenlők, így

$$
\Theta_{\mathrm{E}} \equiv \arccos \frac{\frac{\partial R}{\partial p} \sqrt{g_{R R}}}{\sqrt{\left(\frac{\partial R}{\partial p}\right)^{2} g_{R R}+\left(\frac{\partial \varphi}{\partial p}\right)^{2} g_{\varphi \varphi}}}=\arccos \left[\frac{\left(\frac{d R}{d \varphi}\right)^{2} g_{R R}}{\left(\frac{d R}{d \varphi}\right)^{2} g_{R R}+g_{\varphi \varphi}}\right]^{1 / 2} .
$$

A (4.55) képletben minden függvénynek az O pontban felvett értékét tekintjük.

\subsubsection{Az elsố relativisztikus Einstein gyứrú}

A (4.53) pálya alak egyenlet a (3.3) metrika behelyettesítésével a

$$
\frac{d R}{d \varphi}= \pm\left[\left(\frac{E m}{L}\right)^{2} R^{4}-R^{2}+2 R-\frac{q}{m^{2}}\right]^{1 / 2}
$$

alakot ölti. $L / m E$ a dimenziótlan impakt paraméter. A dimenziótlanított minimális megközelítési távolság $\left(R_{\min }:=r_{\min } / m\right)$ a szögletes zárójelben látható negyedfokú polinom legnagyobb gyöke. Az Einstein szög (4.55) képlete pedig a (3.3) téridőben

$$
\Theta_{\mathrm{E}}=\arccos \left[1-\left(\frac{L}{E D_{L}}\right)^{2}\left(1-\frac{2 m}{D_{L}}+\frac{q}{D_{L}^{2}}\right)\right] .
$$

A csillagszerú forrást az optikai tengelyre helyezzük, amit a szupermasszív fekete lyuk és a GALAXY interferométer definiál. $L / m E$ minden értéke az $[1,10]$ intervallumban meghatároz egy null geodetikust, amit az (4.56) egyenlet numerikus fejlesztésével elő lehet állítani. Az értékek többsége nem vezet olyan görbéhez, ami megfelelne az $\mathrm{S}$ és $\mathrm{O}$ pontok által adott határfeltételnek. Ezért $L / m E$-t "finomhangolni" kell ahhoz, hogy olyan görbét kapjunk, amely a 4.7 ábrának megfelel, azaz átmegy az $\mathrm{S}$ és $\mathrm{O}$ pontokon, és egyszer megkerüli a lencsét.

A numerikus fejlesztés során - adott $q \in\left[-5 m^{2},+2 m^{2}\right]$ és $D_{\mathrm{LS}} \in\left[10 \mathrm{pc}, 10^{5} \mathrm{pc}\right]$ paraméterek rögzítése után - a foton $D_{\mathrm{LS}} / m$ távolsága $R_{\text {min }}$-re csökken, majd $D_{\mathrm{L}} / m$-re nô. A numerikus integrálás eredménye a foton $\Delta \varphi$ polárszög változása. Az $L / m E=10$ értékkel $\Delta \varphi>3 \pi$ adódik. Ezért $L / m E$ értékét addig csökkentettük, amíg a $\Delta \varphi=3 \pi \pm 10^{-12}$ eredmény állt elő.

A megfelelő $L / m E$ értéket végül behelyettesítettük a (4.57) képletbe, és kiszámoltuk a rögzített $q$ és $D_{\mathrm{LS}}$ paraméterekhez tartozó Einstein sugarat, $\Theta_{\mathrm{E}}=\Theta_{\mathrm{E}}\left(q_{\min }, D_{\mathrm{LS}}\right)$.

\subsubsection{Kényszerek megállapítása az árapálytöltésre}

A $q_{\min }$ és $q_{\max }$ kényszereket a (4.50) mérési hiba alapján határozzuk meg, a Schwarzschild esetben várható $\Theta_{\mathrm{E}}\left(0, D_{\mathrm{LS}}\right)=26 \mu$ as Einstein sugár ismeretében. A 4.1. táblázatban a $\Theta_{\mathrm{E}}\left(0, D_{\mathrm{LS}}\right)$ érték a $q=0$ árapálytöltéshez tartozik. A táblázat a $D_{\mathrm{LS}}=10 \mathrm{pc}$ választás mellett készült. $\mathrm{Az}$ árapálytöltés megengedett értékei tehát $\Theta_{\mathrm{E}}\left(0, D_{\mathrm{LS}}\right) \pm \Delta \Theta$ Einstein szög intervallumba esnek. Ezért $q_{\min }$ és $q_{\max }$ definíciója

$$
\begin{aligned}
\Theta_{\mathrm{E}}\left(q_{\mathrm{min}}, D_{\mathrm{LS}}\right) & =\Theta_{\mathrm{E}}\left(0, D_{\mathrm{LS}}\right)+\Delta \Theta, \\
\Theta_{\mathrm{E}}\left(q_{\mathrm{max}}, D_{\mathrm{LS}}\right) & =\Theta_{\mathrm{E}}\left(0, D_{\mathrm{LS}}\right)-\Delta \Theta .
\end{aligned}
$$

Az elsố relativisztikus Einstein gyűrű sugarának vizsgálata a szupermasszív fekete lyuk árapálytöltésére a

$$
q \in\left[q_{\min }, q_{\max }\right]=\underset{44}{[-1.815,0.524] \times 10^{20} \mathrm{~m}^{2}}
$$


4.1. táblázat. A GALAXY mérési pontossága által megengedett Einstein sugár értékek (1. oszlop), és az ezeknek megfeleltetett árapálytöltések (5.-6. oszlop), ha $D_{\mathrm{LS}}=10$ pc. 2 . oszlop: a minimális megközelítés távolsága, 3. oszlop: ütközési paraméter, 4. oszlop: a horizont sugara, amennyiben a horizont létezik, vagy csupasz szingularitás (n.s).

\begin{tabular}{cccccc}
\hline $\begin{array}{c}\Theta_{\mathrm{E}} \\
\mu \mathrm{aS}\end{array}$ & $\frac{r_{\min }}{m}$ & $\frac{L}{m E}$ & $\frac{r_{\mathrm{H}}}{m}$ & $\begin{array}{c}q \\
{\left[10^{20} \mathrm{~m}^{2}\right]}\end{array}$ & $\frac{q}{m^{2}}$ \\
\hline 38 & 4.9 & 7.7 & 3.3 & -1.815 & -4.5 \\
34 & 4.2 & 6.7 & 2.8 & -1.008 & -2.5 \\
30 & 3.7 & 6.1 & 2.4 & -0.491 & -1.2 \\
26 & 3.0 & 5.2 & 2.0 & 0.000 & 0.0 \\
22 & 2.5 & 4.4 & 1.6 & 0.148 & 0.3 \\
18 & 1.9 & 3.8 & 1.1 & 0.268 & 0.7 \\
14 & 1.4 & 3.2 & n. s. & 0.524 & 1.3 \\
\hline
\end{tabular}

4.2. táblázat. A tömeg négyzetével normált árapálytöltésre vonatkozó kényszerek összehasonlító táblázata. 2. oszlop: a Napra érvényes kényszer, a Föld perihélium precessziója alapján. 3. oszlop: kettôs neutroncsillagok oszcillációja alapján. 4. oszlop: a neutroncsillagok kompaktsági határa alapján. 5. oszlop: az általunk számolt kényszer a szupermasszív fekete lyuk (SMBH) lencse esetében.

\begin{tabular}{ccccc}
\hline Égitest & Nap & kettôs n. cs. & neutroncsillag & SMBH \\
\hline$\left|\mathrm{q} / \mathrm{M}^{2}\right|_{\max }$ & 0.003 & 2.339 & 227.647 & 4.485 \\
\hline
\end{tabular}

kényszert adja.

Egyéb égitestekre megállapított kényszerek a következők. A Napra vonatkozó legerôsebb kényszert a Föld perihélium precessziója szolgáltatja $|q| \leq 6 \times 10^{3} \mathrm{~m}^{2}$ [48]. A [47] cikk a kettős neutroncsillagok oszcillációjának modelljeiből a $|q|<10^{7} \mathrm{~m}^{2}$ kényszert állapítja meg. A bránon lévő neutroncsillag állapotegyenlete alapján, az egyenletet konstans súrúségú átlagos tömegú neutron csillagra alkalmazva a bránfeszültségre $\lambda>5 \times 10^{8} \mathrm{MeV}^{4}$ [97] adódik. Ebból a neutroncsillag felszínéhez illesztett (3.3) metrikájú téridő árapálytöltésére a $-9.730 \times 10^{8}$ $\mathrm{m}^{2}<q<0$ összefüggés adódik.

A Naprendszerben a fényelhajlási szög vizsgálatából kapott kényszer a Napra $|q| \leq 2.966 \times$ $10^{9} \mathrm{~m}^{2}[46]$.

A $q / m^{2}$ dimenziótlan mennyiségre vonatkozó kényszerek nem terülnek szét olyan sok nagyságrendben, mint a $q$-ra érvényes korlátok. A 4.2. táblázat ezeket a normált kényszereket mutatja be. 


\section{5. fejezet}

\section{A Kehagias-Sfetsos fekete lyuk gravitációs lencsézése}

Ebben a fejezetben a (3.5) metrikájú Kehagias-Sfetsos fekete lyuk által keltett képeket fogjuk tanulmányozni [3]. Az 5.1 ábra a 2.2a ábrának megfelelő konfigurációt ábrázol, és a $b=D_{L} \sin |\theta|$ impakt paramétert is feltünteti. A lencsézés geometriáját jellemző, a 2.2. alfejezetben bevezetett jelöléseket alkalmazzuk. Ebben a fejezetben a $G=1=c$ egységekben dolgozunk.

A (4.8) Virbhadra-Ellis lencseegyenletet használjuk. Az egyenletet az irodalomban gyakran alkalmazzák a relativisztikus lencsézés vizsgálatára is. A $\delta$ elhajlást az egyenlítői síkon elhelyezkedő, végtelenből induló és oda visszatérő null geodetikus tulajdonságai szolgáltatják. A pálya alak egyenlet integrálása elliptikus integrálra vezet [84]:

$$
\delta\left(r_{\min }\right)=2 \int_{r_{\min }}^{\infty} \frac{1}{r}\left[\frac{g_{r r}(r)}{\frac{g_{t t}\left(r_{\min }\right)}{g_{t t}(r)}\left(\frac{r}{r_{\min }}\right)^{2}-1}\right]^{1 / 2} d r-\pi .
$$

Az $r_{\min }$ minimális megközelítés távolságának definíciója (4.54). Az $\alpha=\arcsin \left(r_{\min } / r\right)$ változócsere eltávolítja (5.1) integrandusából az $r=r_{\min }$ pontban lévố szingularitást. Ez lehetôvé teszi a numerikus integrálást $\left(x_{0}:=r_{\min } / 2 m\right)$ :

$$
\delta\left(x_{0}\right)=2 \int_{0}^{\pi / 2}\left[1+\frac{8\left(\sin ^{3} \alpha-1\right)\left(\tan ^{2} \alpha+1\right) \omega_{0} x_{0}}{\left(16 \omega_{0}^{2} x_{0}^{4}+8 \omega_{0} x_{0} \sin ^{3} \alpha\right)^{1 / 2}+\left(16 \omega_{0}^{2} x_{0}^{4}+8 \omega_{0} x_{0}\right)^{1 / 2}}\right]^{-1 / 2} d \alpha-\pi .
$$

Az $\omega_{0} \rightarrow \infty$ limesz a Schwarzschild elhajlási szöget adja, az $\omega_{0} \rightarrow 0$ határeset nullát. Ha pedig $m=0$, akkor $\delta=0$, függetlenül $\omega$ értékétől. Az $m, x_{0}$ és $\delta\left(x_{0}\right)$ mennyiségek azonos előjelúek, a Schwarzschild lencsézéshez hasonlóan.

A [46] cikk logikáját követve $r_{\min }$ definícióját felváltjuk egy algebrai egyenlettel. A null geodetikusok Lagrange függvénye az egyenlítôi síkon

$$
2 \mathcal{L}=g_{t t}(r) \dot{t}^{2}+g_{r r}(r) \dot{r}^{2}+r^{2} \dot{\varphi}^{2}=0
$$

a pont a görbe paramétere szerinti deriválást jelöli. A $t$ és $\varphi$ ciklikus koordináták az $E=-g_{t t} \dot{t}$ és $L=r^{2} \dot{\varphi}$ mozgásállandókat adják. Ezeket visszahelyettesítve a (5.3) egyenletbe, a pálya egyenlet az $u=r^{-1}$ változóban

$$
g_{r r} u^{\prime}=g_{t t}^{-1}\left(\frac{E}{L}\right)^{2}-u^{2}
$$


a vessző deriválást jelöl $\varphi$ szerint. Az $\mathrm{r}_{\min }$ helyen, a (4.54) egyenlet alapján

$$
\begin{aligned}
& 0=\left(\frac{L}{E}\right)^{2} g_{t t}\left(r_{\min }\right)+r_{\min }^{2}, \\
& 0=g_{t t}\left(r_{\min }\right) D_{L}^{2} \sin ^{2} \theta+r_{\min }^{2} .
\end{aligned}
$$

A képek helyzetét a (4.8), (5.2), (5.6) egyenletrendszer numerikus megoldása adja.

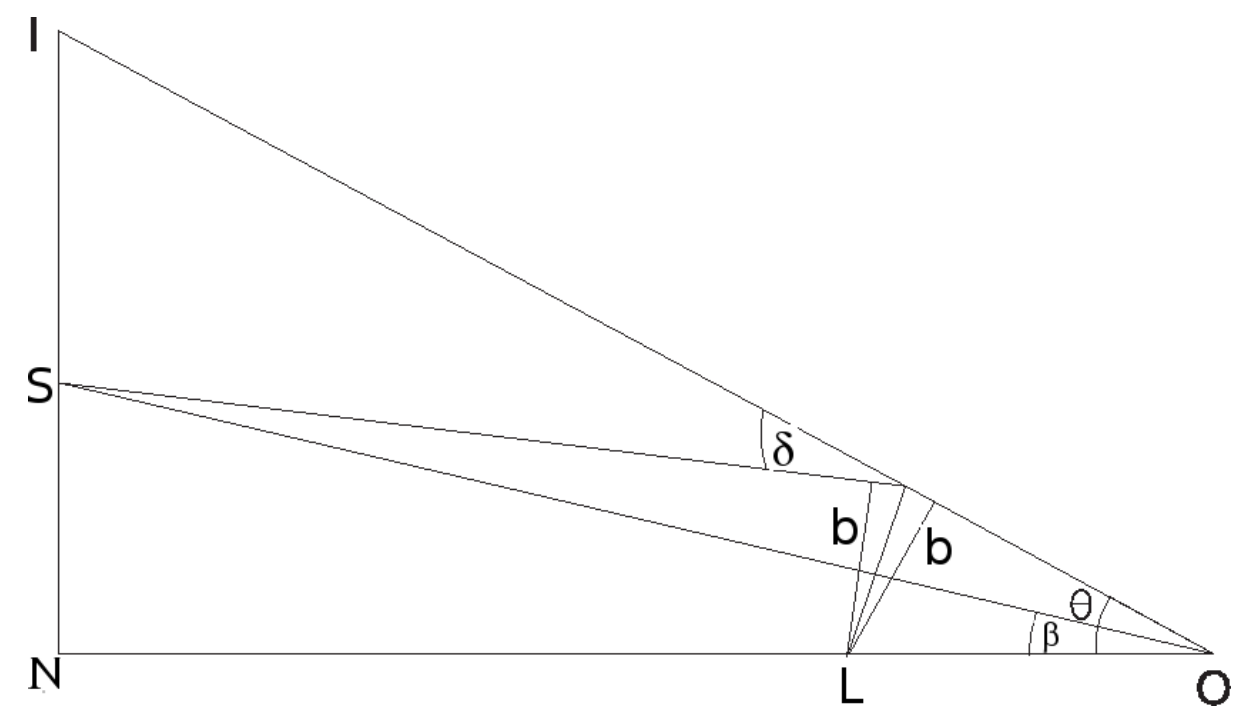

5.1. ábra. A gyenge lencsézés geometriája pozitív $\theta$ látszó szög és $\delta$ elhajlás esetén.

\subsection{A képek helyzete a Kehagias-Sfetsos téridóben}

A tömeg helyett az $\bar{\varepsilon}=m / d$, a HL paraméter helyett a $\bar{\lambda}=1 / \omega d^{2}$ dimenziótlan paramétert használjuk ( $\left.d=D_{L} D_{S} / D_{L S}\right)$. Ezek a paraméterek így a lencsézési geometriáról is hordoznak információt. A $\theta / \beta$ és $\bar{\varepsilon} / \beta^{2}$ normált paraméterek bevezetésével (feltéve, hogy $\beta \neq 0$ ) pedig eredményeink függetlenek lesznek a $\beta$ forrás helyzet önkényes megválasztásától. A paraméterekre fennáll, hogy

$$
\omega_{0} \bar{\lambda}=\bar{\varepsilon}^{2},
$$

következésképpen a (3.7) fekete lyuk feltétel kifejezhető

$$
\bar{\varepsilon}^{2} \geq \frac{\bar{\lambda}}{2}
$$

alakban.

Negatív lencse tömeg esetén $\bar{\lambda}$ nem lehet tetszőlegesen nagy, mert $g_{t t}<0$ miatt $1+$ $4 m / \omega r^{3} \geq 0$. Ezért

$$
\bar{\lambda} \leq \bar{\lambda}^{\text {crit }}=\frac{1}{4}\left(\frac{r_{\min }}{d}\right)^{3}(-\bar{\varepsilon})^{-1}
$$

\subsubsection{Einstein gyứrúk keletkezése}

Einstein gyưrú keletkezik, amikor a forrás, a lencse és a megfigyelő az optikai tengelyen van. A (4.8), (5.2), (5.6) egyenletrendszer numerikus megoldása a $\beta=0, s=1$ feltevés mellett a $\left(\theta_{E}, r_{\min } / d, \delta\right)$ számhármast adja az $\bar{\varepsilon}$ és $\bar{\lambda}$ paraméterek függvényében. A $\theta_{E}$ Einstein szögeket 


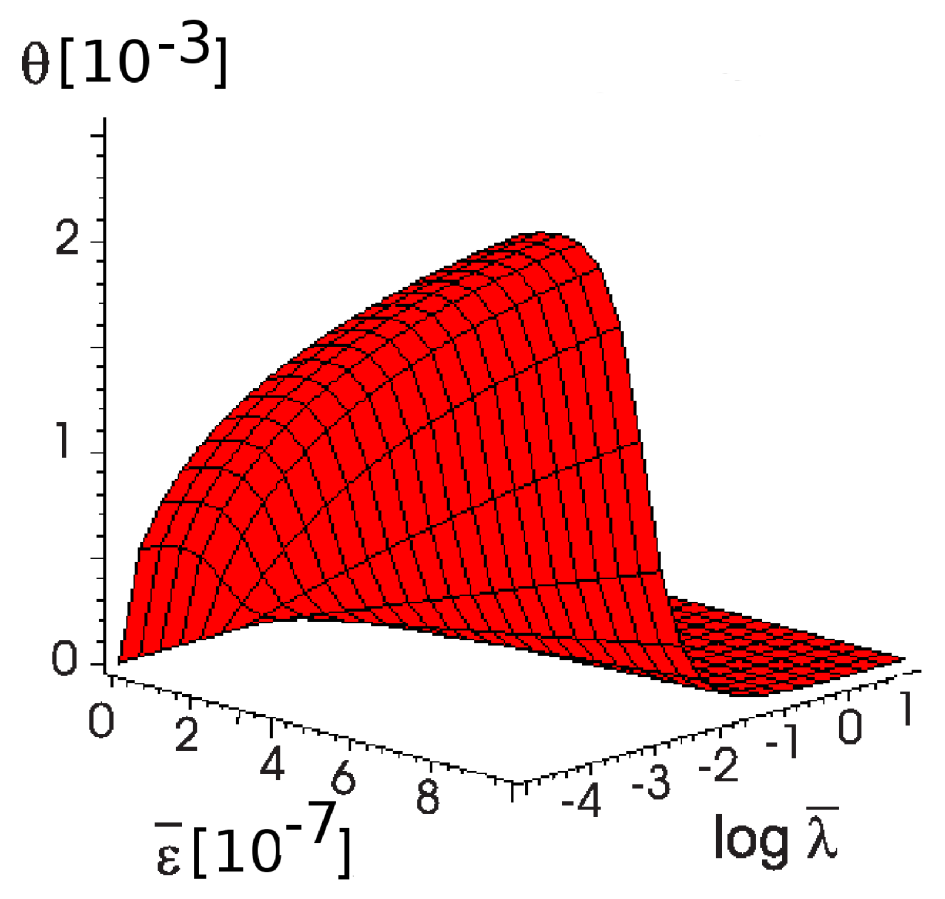

5.2. ábra. Az Einstein gyưrú sugara az $\bar{\varepsilon}$ tömeg paraméter és $\bar{\lambda}$ normált HL paraméter függvényében, a Kehagias-Sfetsos téridőben, a $D_{L S} / D_{L}=2$ választás mellett. Ha $\bar{\lambda} \rightarrow 0$ akkor a Schwarzschild eredményt kapjuk. $\bar{\lambda}$ növekedésével a metrika síkká válik, így az Einstein szög összemegy. 


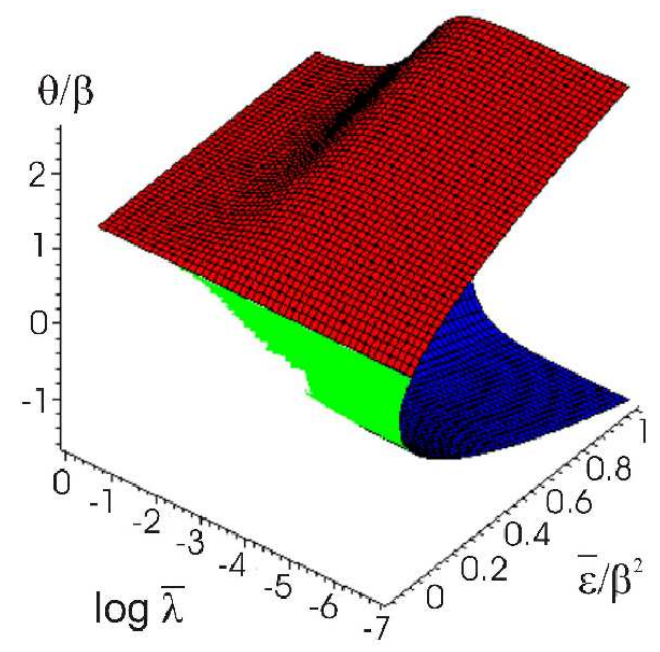

a)

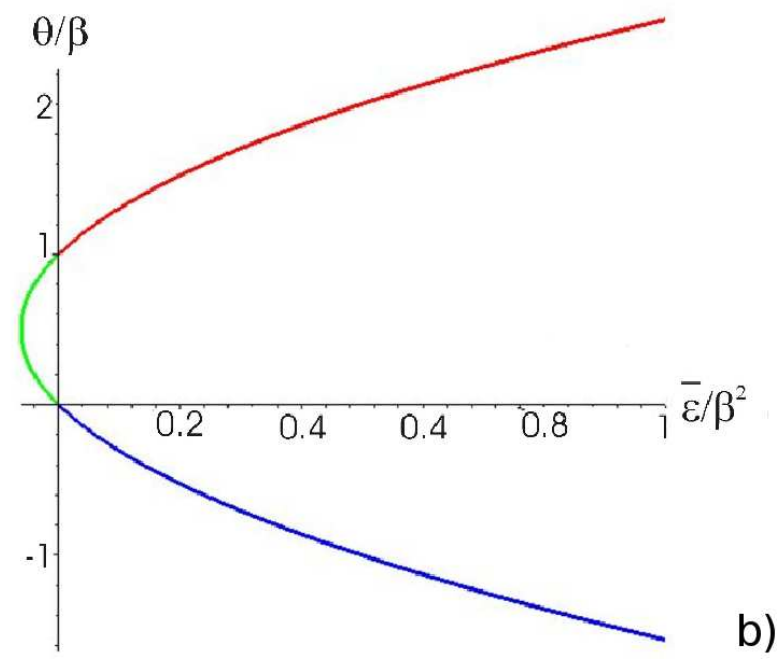

5.3. ábra. Az (a) ábrán a képek helyzete látható $\bar{\varepsilon} / \beta^{2}$ és $\log \bar{\lambda}$ függvényében, ha $D_{L S} / D_{L}=2$. A felület három részből áll: a fókuszált pozitív képek (piros), a fókuszált negatív képek (kék), a szórt képek (zöld). $\bar{\lambda}$ növekedése során csak a pozitív kép marad meg. Nagyon nagy $\bar{\lambda}$-ra a metrika kisímul, az elhajlás megszúnik. A (b) ábrán a $\bar{\lambda} \rightarrow 0$ Schwarzschild határeset található.

a 5.2 ábra mutatja be, a $D_{L S} / D_{L}=2$ konfiguráció esetén. Ha $\bar{\lambda} \rightarrow 0$, akkor a Schwarzschild lencsézésre jellemző fél-parabola alakú metszetet kapjuk. Rögzített $\bar{\varepsilon}$ mellett, ahogy $\bar{\lambda}$ nő, a fél-parabola összecsukódik, jelezve a gravitáció csökkenését. Ha $\bar{\lambda}$ a végtelenbe tart, akkor $\theta_{E} \rightarrow 0$. Adott tömeg és lencsézési geometria (azaz $D_{L S} / D_{L}$ arány) esetén az Einstein szögek a Kehagias-Sfetsos téridôben minden $\bar{\lambda}$-ra kisebbek a Schwarzschild értéknél.

\subsubsection{Képek keletkezése}

Általános $\beta>0$ helyzetú forrás esetén, az egyenletrendszer megoldása $\left(\theta / \beta, r_{\min } / d, \delta\right)$. A képek helyzetét az 5.3 ábra mutatja. A felület három részén különböző típusú képek vannak. A fókuszált pozitív képek a felső, piros felületen. A fókuszált negatív képek az alsó, kék felületen. A negatív tömegú lencse által szórt képek a középső, zöld felületen.

A felület $\bar{\lambda}=0$ metszete (mely szigorúan véve csak limeszként létezik, azaz a felület nyitott) egy parabolikus él. Ez az él ábrázolja a Kehagias-Sfetsos téridő Schwarzschild határesetében a képek keletkezését.

Ahogy $\bar{\lambda}$ nô, a képek közelebb kerülnek a tengelyhez. Az alsó felületnek éles széle van, amikor $\bar{\lambda} \rightarrow \mathcal{O}\left(10^{-3}\right)$. A $\bar{\lambda}$ további növekedésére a téridő sík lesz és $\theta / \beta \rightarrow 1$, azaz nem történik elhajlás. A negatív képek hirtelen eltúnését $\bar{\lambda}$ növelésekor úgy magyarázzuk meg, ha előbb a $\delta\left(r_{\min }\right)$ függést vesszük szemügyre (5.4 ábra). Minden $\omega$-hoz létezik egy maximális $\delta_{\max }$, amely egy megfelelő $r_{\text {crit }}$-hez tartozik. Minden sugár, amely $r_{\text {crit }}$-nél közelebb vagy távolabb közelíti meg a lencsét, kevésbé térül el, mint az $r_{\text {crit }}$ távolságban megtörő sugár.

A negatív képeket létrehozó sugarakra $\delta$ nagyobb, mint a pozitív képekért felelős sugarakra, 1. 5.5 ábra. Minden tömeg és lencsézési geometria esetén valamilyen $\omega$-ra még a hozzá tartozó $\delta_{\max }$ sem elegendôen nagy, hogy az optikai tengely alatt $r_{\text {crit }}$ távolságban elhaladó fénysugár eljusson a megfigyelőhöz. Ezért negatív kép nem jön létre, 1. 5.6 ábra. 


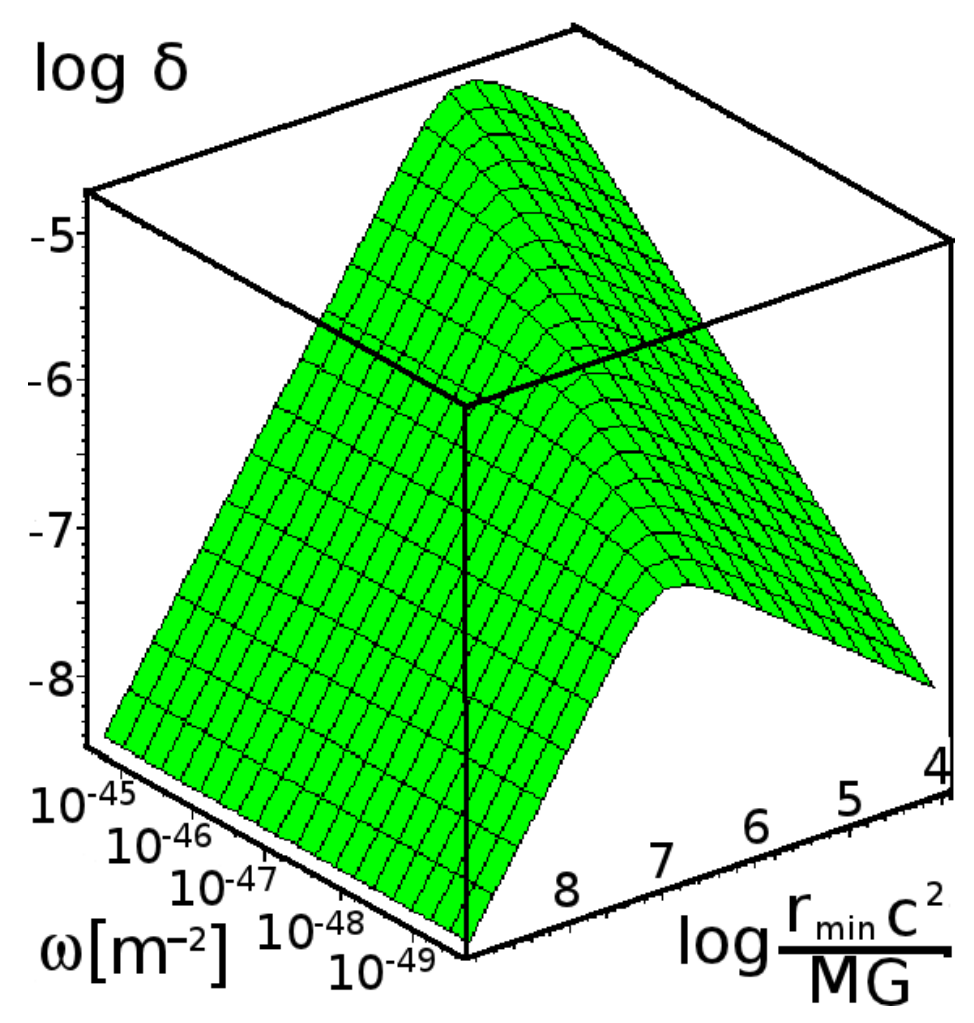

5.4. ábra. $\delta$ logaritmusa $\omega$ és a minimális megközelítés távolsága függvényében. Az ábrázolt $\omega$ tartomány megfelel az 5.3 ábra $\bar{\lambda}$ tartományának. A lencse tömege $4.284 \cdot 10^{14}$ méter, $D_{S}=$ $4.190 \cdot 10^{25}$ méter és $D_{L S} / D_{L}=2$. Minden $\omega$-hoz létezik egy maximális $\delta_{\max }$, amely egy megfelelő $r_{\text {crit }}$-hez tartozik. A kritikus $r_{\text {crit }}$ távolság csökken ha $\omega$ nô. Minden sugár, amely $r_{\text {crit }}{ }^{-}$ nél közelebb vagy távolabb közelíti meg a lencsét, kevésbé térül el, mint az $r_{\text {crit }}$ távolságban megtörő sugár.

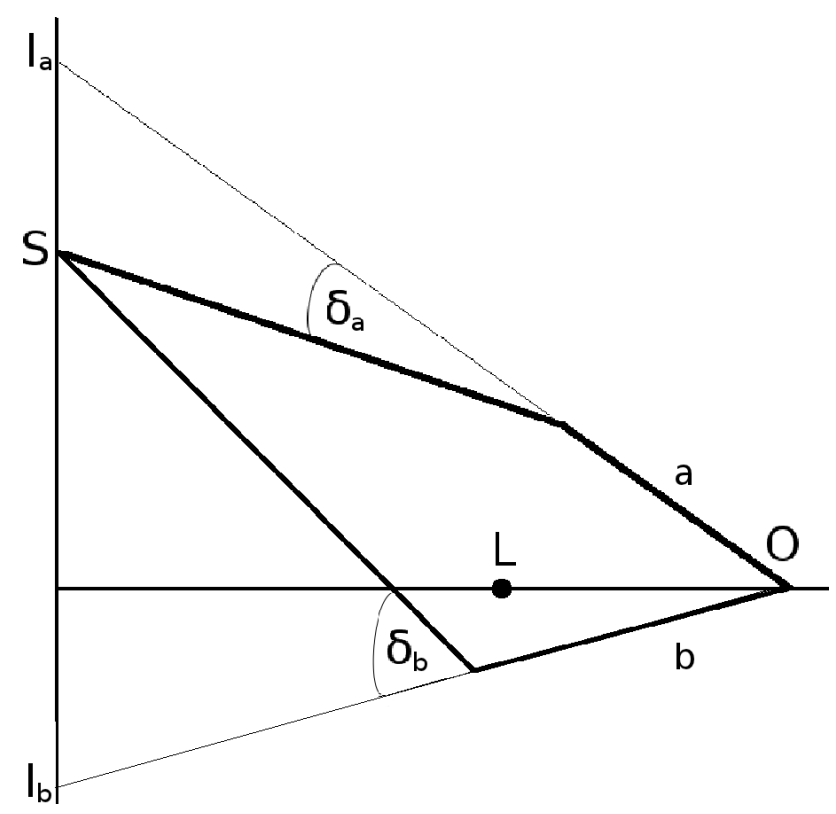

5.5. ábra. Az (a) és (b) sugarak, a hozzájuk tartozó pozitív és negatív képpel ( $\mathrm{I}_{a}$ és $\left.\mathrm{I}_{b}\right)$. Az elhajlási szögekre $\delta_{(b)}>\delta_{(a)}$ érvényes. 


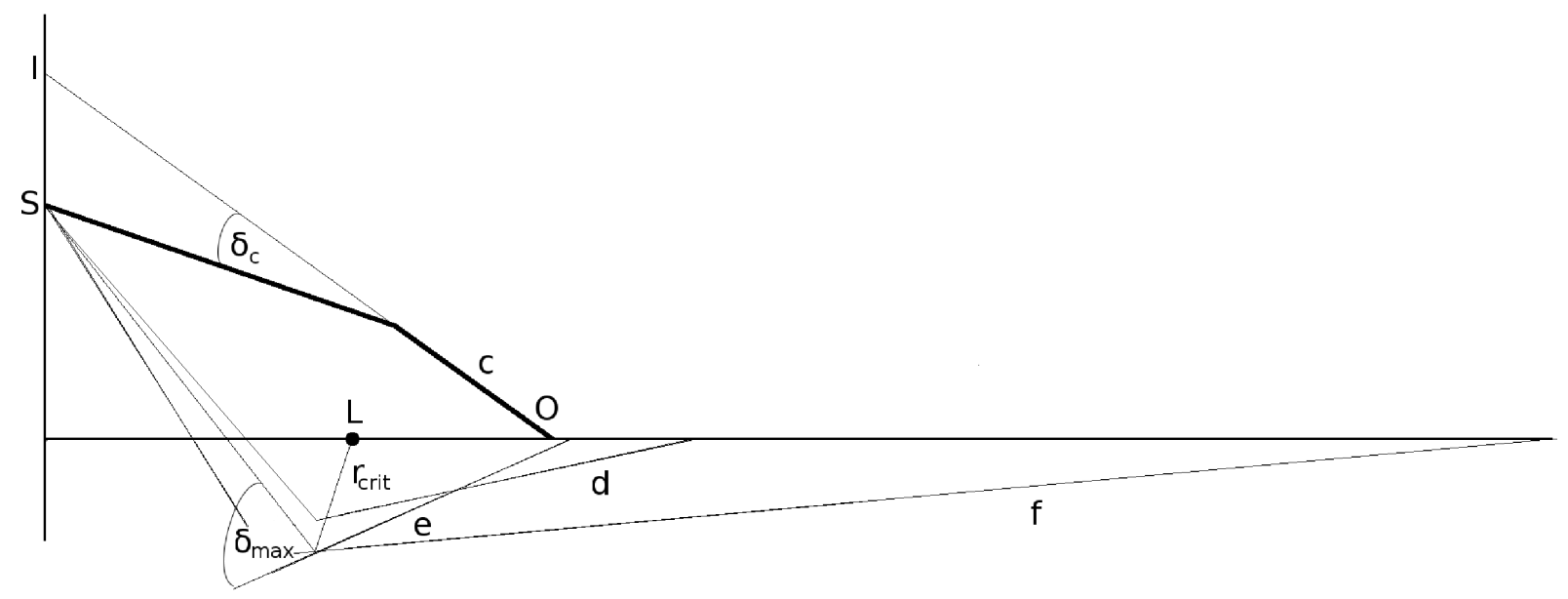

5.6. ábra. Valamely $\omega$-hoz elegendően kicsiny $\delta_{\max }$ tartozik, hogy a felsô kép (c) létrejön, de

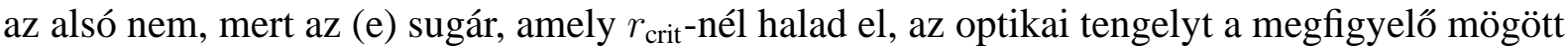
metszi. Minden sugár, függetlenül attól, hogy a $r_{\min }$-jük kisebb (d) vagy nagyobb (f) mint $r_{\text {crit }}$, még távolabb metszi a tengelyt.

\subsection{Kényszerek megállapítása a Hořava-Lifshitz paraméterre}

A Large Synoptic Survey Telescope nagyszámú gravitációs lencse galaxis felfedezését tette lehetôvé [85]. A Sloan Lens Advanced Camera and Spectrograph Survey (SLACS) majdnem 100 lencse galaxist észlelt és mért [86]. A legtöbb lencsét a SLACS-ból a [87] cikk elemezte. A lencse galaxisokat a Sloan Digital Sky Survey (SDSS) spektroszkópiai adatbázisából szelektálják. A kiválasztás azon alapul, hogy az égen egy adott irányban egy távolabbi (vörösebb) és egy közelebbi (kékebb) galaxis észlelhető.

\subsubsection{Kényszerek gyenge lencsézésből}

Ebben a szakaszban a gyenge lencsézés során keletkező Einstein gyưrúk vizsgálata alapján állapítunk meg kényszert a HL paraméterre. A Hubble Ûrtávcső képein az Einstein gyưrúk sugarait mérni lehet, a megfigyelt szögek a [0.69 as, 1.78 as] intervallumba esnek. A mérésekhez az ACS-WFC (Advanced Camera for Surveys, Wide Field Channel) kamerát használták, amelynek pixelmérete 0.049 as [88]. Ezért rögzítjük a szögmérés hibáját:

$$
\Delta \theta:=0.049 \text { as. }
$$

A $\Delta \theta$ pontosságú méréssel természetesen nem lehetséges a relativisztikus képek vizsgálata, hiszen ezek szögátmérője több nagyságrenddel kisebb, mint a gyenge lencsézés során keletkező képeké. Ezért volt szükség a (4.50) pontosságra a 4.2 alfejezetben.

57 lencse galaxis fotometriai és spektroszkópiai mérései szerepelnek a [87] cikk 1. táblázatában. Több-szín fotometria és különféle lencse modellek alkalmazásával a cikk tanulmányozta a galaxisok felépítését a világító és a sötét anyag aránya szempontjából.

A $\Delta \theta$ mérési hiba létezése megengedi, hogy a HL paraméterre fennálljon az $\omega \in\left(\omega_{\min }, \infty\right)$ kényszer. A kritikus $\omega_{\min }$ alsó határ az $\theta_{E}\left(\omega_{\min }\right)=\theta_{E, S c h}-\Delta \theta$ összefüggésnek tesz eleget. $\theta_{E, S c h}$ az Einstein sugár Schwarzschild értékét jelöli (amely folytonossági megfontolásból a $\lim _{\omega \rightarrow \infty} \theta_{E}\left(\omega_{\min }\right)$ határértékkel azonos). A kényszert kielégítő bármely $\omega$-ra az Einstein szöget megfigyeléssel nem lehet megkülönböztetni $\theta_{E, S c h}$-tôl.

A 5.1 és 5.2 táblázat szerkezete a következô. Az 1.-3. oszlopok a [87] cikk 1. táblázatából származnak. Az 1. oszlopban felsorolt galaxisok által létrehozott Einstein gyưrúk szögsugarai a 2. oszlopban találhatók. A 3. oszlop az $R_{E}=D_{L} \theta_{E}$ effektív Einstein sugáron belül lévő 
5.1. táblázat. 1. oszlop: lencse galaxisok. 2.-5. oszlopok: Einstein szög $\theta_{E}$, lencse tömeg az Einstein gyúrúben, $D_{L}, D_{L S}$. 6. oszlop: $r_{\min }, 7 .-8$. oszlop: $\omega_{\min }, \omega_{0, \min }$.

\begin{tabular}{|c|c|c|c|c|c|c|c|}
\hline galaxis & $\theta_{E}$ & $\mathrm{M}$ & $D_{L}$ & $D_{S}$ & $r_{\min }$ & $\omega_{\min }$ & $\omega_{0, \min }$ \\
\hline & {$[\mathrm{as}]$} & {$\left[10^{10} M_{\odot}\right]$} & {$[\mathrm{Mpc}]$} & {$[\mathrm{Mpc}]$} & {$[\mathrm{Kpc}]$} & {$\left[10^{-48} \mathrm{~cm}^{-2}\right]$} & {$\left[10^{-16}\right]$} \\
\hline $\mathrm{J} 0008-0004$ & 1.16 & 35 & 1172.743 & 1708.956 & 6.595 & 0.18942 & 5.0657 \\
$\mathrm{~J} 0029-0055$ & 0.96 & 12 & 750.391 & 1622.253 & 3.492 & 0.27033 & 0.84982 \\
$\mathrm{~J} 0037-0942$ & 1.53 & 29 & 669.889 & 1411.834 & 4.969 & 0.34628 & 6.3576 \\
$\mathrm{~J} 0044+0113$ & 0.79 & 9 & 446.200 & 672.576 & 1.709 & 1.2219 & 2.1606 \\
$\mathrm{~J} 0109+1500$ & 0.69 & 13 & 905.964 & 1291.699 & 3.031 & 0.33425 & 1.2332 \\
$\mathrm{~J} 0157-0056$ & 0.79 & 26 & 1276.277 & 1618.923 & 4.888 & 0.23749 & 3.5047 \\
$\mathrm{~J} 0216-0813$ & 1.16 & 49 & 984.161 & 1289.158 & 5.535 & 0.35670 & 18.697 \\
$\mathrm{~J} 0252+0039$ & 1.04 & 18 & 875.400 & 1644.710 & 4.414 & 0.22816 & 1.6138 \\
$\mathrm{~J} 0330-0020$ & 1.10 & 25 & 1020.790 & 1676.984 & 5.444 & 0.20053 & 2.7361 \\
$\mathrm{~J} 0405-0455$ & 0.80 & 3 & 293.680 & 1555.222 & 1.139 & 1.1703 & 0.22993 \\
$\mathrm{~J} 0728+3835$ & 1.25 & 20 & 696.489 & 1463.700 & 4.221 & 0.32141 & 2.8066 \\
$\mathrm{~J} 0737+3216$ & 1.00 & 29 & 964.236 & 1358.283 & 4.675 & 0.30324 & 5.5673 \\
$\mathrm{~J} 0822+2652$ & 1.17 & 24 & 784.904 & 1372.544 & 4.452 & 0.30991 & 3.8969 \\
$\mathrm{~J} 0903+4116$ & 1.29 & 45 & 1157.167 & 1675.061 & 7.237 & 0.19736 & 8.7248 \\
$\mathrm{~J} 0912+0029$ & 1.63 & 40 & 580.506 & 968.258 & 4.587 & 0.60497 & 21.131 \\
$\mathrm{~J} 0935-0003$ & 0.87 & 41 & 1013.21 & 1213.066 & 4.274 & 0.48386 & 17.756 \\
$\mathrm{~J} 0936+0913$ & 1.09 & 15 & 653.631 & 1366.016 & 3.454 & 0.36699 & 1.8026 \\
$\mathrm{~J} 0946+1006$ & 1.38 & 29 & 737.793 & 1388.471 & 4.936 & 0.32025 & 5.87966 \\
$\mathrm{~J} 0956+5100$ & 1.33 & 37 & 782.476 & 1217.394 & 5.045 & 0.37351 & 11.163 \\
$\mathrm{~J} 0959+4416$ & 0.96 & 17 & 775.156 & 1299.251 & 3.608 & 0.33752 & 2.1294 \\
$\mathrm{~J} 0959+0410$ & 0.99 & 8 & 465.339 & 1304.229 & 2.233 & 0.58732 & 0.82058 \\
$\mathrm{~J} 1016+3859$ & 1.09 & 15 & 592.045 & 1171.202 & 3.129 & 0.47174 & 2.3171 \\
$\mathrm{~J} 1020+1122$ & 1.20 & 34 & 879.827 & 1326.068 & 5.119 & 0.31376 & 7.9181 \\
$\mathrm{~J} 1023+4230$ & 1.41 & 23 & 656.356 & 1470.562 & 4.487 & 0.34248 & 3.9551 \\
$\mathrm{~J} 1029+0420$ & 1.01 & 6 & 393.820 & 1394.687 & 1.928 & 0.73490 & 0.57756 \\
$\mathrm{~J} 1100+5329$ & 1.52 & 47 & 954.102 & 1584.325 & 7.031 & 0.22552 & 10.875 \\
$\mathrm{~J} 1106+5228$ & 1.23 & 9 & 366.879 & 1119.963 & 2.188 & 0.90303 & 1.5968 \\
$\mathrm{~J} 1112+0826$ & 1.49 & 45 & 859.747 & 1408.858 & 6.211 & 0.28347 & 12.531 \\
\hline
\end{tabular}

sötét + világító tömeget tartalmazza. A [87] cikk 1. táblázatában található $z_{L}$ lencse vöröseltolódásokat és $z_{S}$ forrás vöröseltolódásokat átszámoltuk szögátmérő-távolságokká (4. oszlop: $D_{L}$, 5. oszlop: $\left.D_{L S}\right)$. Az átszámolás folyamán a $H_{0}=70 \mathrm{~km} / \mathrm{s} / \mathrm{Mpc}$ Hubble paraméterrel és a $\Omega_{\Lambda}=0.7, \Omega_{M}=0.3$ kozmológiai paraméterekkel dolgoztunk. Az adatokból az $r_{\min }$ távolságot (6. oszlop) és az $\omega_{\min }, \omega_{0, \min }:=\left(G M_{\text {lum+dark }} / c^{2}\right)^{2} \omega_{\text {min }}$ kényszereket (7., 8. oszlop) numerikusan számoltuk ki, az (5.10) mérési pontosság figyelembe vételével.

\subsubsection{Kényszerek relativisztikus lencsézésből}

A Multi Adaptive Optics Imaging Camera for Deep Observations kamerát úgy tervezték, hogy $10^{-5}$ as pontosságú asztrometriára legyen képes [83]. Ez a relativisztikus képek nagyságrendje. Ezért kényszereket állapíthatunk meg a HL paraméterre relativisztikus lencsézésből is.

A 4.7 ábrán látható konfiguráció alkalmas erre. Legyen a lencse a szupermasszív fekete lyuk a Galaxis magjában. A forrást helyezzük a Galaxis másik oldalára, úgy hogy $D_{L}=8.3$ kpc és $D_{S}=2 D_{L}$. A Schwarzschild esetben az 1. relativisztikus Einstein szög $2.557 \cdot 10^{-5}$ as, a második $2.554 \cdot 10^{-5}$ as [82]. A $\Delta \theta_{E}=10^{-5}$ as mérési hibakorlát figyelembevételével 
5.2. táblázat. A 5.1. táblázat folytatása. 1. oszlop: lencse galaxisok. 2.-5. oszlopok: Einstein szög $\theta_{E}$, lencse tömeg az Einstein gyürúben, $D_{L}, D_{L S}$. 6. oszlop: $r_{\min }$, 7.-8. oszlop: $\omega_{\min }$,

\begin{tabular}{|c|c|c|c|c|c|c|c|}
\hline galaxis & $\theta_{E}$ & $\mathrm{M}$ & $D_{L}$ & $D_{S}$ & $r_{\min }$ & $\omega_{\min }$ & $\omega_{0 \text { min }}$ \\
\hline & [as] & {$\left[10^{10} M_{\odot}\right]$} & [Mpc] & {$[\mathrm{Mpc}]$} & [Kpc] & {$\left[10^{-48} \mathrm{~cm}^{-2}\right\rceil$} & {$\left[10^{-16}\right]$} \\
\hline J1134+6027 & 1.10 & 13 & 548.213 & 1223.120 & 2.924 & 0.49304 & 1.8190 \\
\hline $\mathrm{J} 1142+1001$ & 0.98 & 17 & 737.793 & 1264.429 & 3.505 & 0.36081 & 2.2764 \\
\hline J1143-0144 & 1.68 & 19 & 400.476 & 1111.614 & 3.262 & 0.79571 & 6.2708 \\
\hline $\mathrm{J} 1153+4612$ & 1.05 & 11 & 626.027 & 1593.810 & 3.187 & 0.34366 & 0.90778 \\
\hline $\mathrm{J} 1204+0358$ & 1.31 & 17 & 580.506 & 1410.844 & 3.687 & 0.41199 & 2.5993 \\
\hline $\mathrm{J} 1205+4910$ & 1.22 & 25 & 719.910 & 1233.014 & 4.258 & 0.37895 & 5.1705 \\
\hline $\mathrm{J} 1213+6708$ & 1.42 & 14 & 455.803 & 1419.669 & 3.138 & 0.7912 & 2.4779 \\
\hline $\mathrm{J} 1218+0830$ & 1.45 & 16 & 493.548 & 1487.965 & 3.470 & 0.5017 & 2.8041 \\
\hline $\mathrm{J} 1250+0523$ & 1.13 & 18 & 762.845 & 1545.386 & 4.179 & 0.27744 & 1.9624 \\
\hline $\mathrm{J} 1402+6321$ & 1.35 & 29 & 693.857 & 1233.014 & 4.541 & 0.38808 & 7.1250 \\
\hline $\mathrm{J} 1403+0006$ & 0.83 & 10 & 650.899 & 1221.693 & 2.619 & 0.41355 & 0.90280 \\
\hline $\mathrm{J} 1416+5136$ & 1.37 & 37 & 916.645 & 1555.865 & 6.088 & 0.23665 & 7.0726 \\
\hline $\mathrm{J} 1420+6019$ & 1.04 & 4 & 250.179 & 1304.222 & 1.261 & 1.6168 & 0.56474 \\
\hline $\mathrm{J} 1430+4105$ & 1.52 & 54 & 886.429 & 1351.555 & 6.532 & 0.30198 & 19.224 \\
\hline $\mathrm{J} 1436-0000$ & 1.12 & 23 & 886.429 & 1551.984 & 4.813 & 0.24263 & 2.8020 \\
\hline $\mathrm{J} 1443+0304$ & 0.81 & 6 & 490.443 & 1139.617 & 1.926 & 0.59752 & 0.46959 \\
\hline J1451-0239 & 1.04 & 8 & 462.168 & 1285.325 & 2.330 & 0.59786 & 0.83530 \\
\hline $\mathrm{J} 1525+3327$ & 1.31 & 48 & 1033.889 & 1487.965 & 6.566 & 0.25047 & 12.598 \\
\hline J1531-0105 & 1.71 & 27 & 568.859 & 1509.087 & 4.716 & 0.40490 & 6.4438 \\
\hline $\mathrm{J} 1538+5817$ & 1.00 & 9 & 518.128 & 1299.251 & 2.512 & 0.50680 & 0.89616 \\
\hline $\mathrm{J} 1621+3931$ & 1.29 & 29 & 794.563 & 1381.108 & 4.969 & 0.30476 & 5.5953 \\
\hline $\mathrm{J} 1627-0053$ & 1.23 & 23 & 701.736 & 1290.430 & 4.185 & 0.36381 & 4.2014 \\
\hline $\mathrm{J} 1630+4520$ & 1.78 & 49 & 801.749 & 1544.046 & 6.919 & 0.26412 & 13.844 \\
\hline $\mathrm{J} 1636+4707$ & 1.09 & 18 & 752.893 & 1451.370 & 3.979 & 0.29974 & 2.1201 \\
\hline J2238-0754 & 1.27 & 13 & 499.736 & 1484.718 & 3.077 & 0.49325 & 1.8198 \\
\hline $\mathrm{J} 2300+0022$ & 1.24 & 30 & 755.390 & 1208.707 & 4.541 & 0.38187 & 7.5028 \\
\hline $\mathrm{J} 2303+1422$ & 1.62 & 27 & 554.146 & 1281.465 & 4.352 & 0.46848 & 7.4556 \\
\hline J2321-0939 & 1.60 & 12 & 318.486 & 1300.500 & 2.470 & 1.0661 & 3.3514 \\
\hline $\mathrm{J} 2341+0000$ & 1.44 & 22 & 642.666 & 1553.284 & 4.487 & 0.33734 & 3.5644 \\
\hline
\end{tabular}

a $\theta_{E}\left(\omega_{\min }\right)=\theta_{E, S c h}-\Delta \theta$ egyenlet megoldása az alkalmazott numerikus pontosság (40 decimális számjegy) erejéig mindkét Einstein gyưrú esetében $\omega_{\min }=8.1315 \cdot 10^{-25} \mathrm{~cm}^{-2}$, ill. dimenziótlanítva $\omega_{0, \min }=0.3282$.

Fontos észrevenni, hogy az $\omega_{0, \text { min }}$ kényszer kisebb 0.5-nél, ezért akár sértheti is a (3.7) fekete lyuk feltételt. Ezen lehetőség kizárásához a $\Delta \theta$ mérési hiba kis mértékú csökkentése szükséges (és elegendő). Ez a jövőbeli méréstechnológián múlik. Mindenesetre az 5.1 és 5.2 táblázatok 8. oszlopával összevetve látható, hogy a relativisztikus lencsézés bevonása a vizsgálatokba kb. 15 nagyságrenddel javítja az $\omega_{0}$-ra megállapított kényszert.

\subsection{3. Összehasonlítás egyéb jelenségekbő́l származó kényszerekkel}

Az irodalomban számoltak kényszereket a HL paraméterre a lencsézéstôl különböző effektusokból is. A [89] cikkben a Merkúr perihélium vándorlása az $\omega_{0, \min }^{(p p)}=6.9 \times 10^{-16}$, a Nap fényelhajlító hatása az $\omega_{0, \text { min }}^{(l d)}=1.1 \times 10^{-15}$, a radarvisszhang késése az $\omega_{0, \text { min }}^{(r e d)}=2 \times 10^{-15}$ kor- 
látot adja. A [90] cikkben a HD209458b exobolygó pályaperiódusából $\omega_{0}^{(\text {Osiris })}=1.4 \times 10^{-18}$ adódott. A [91] cikkben rádió interferometriából az $\omega_{0}^{(\text {radio })} \in\left[10^{-15}, 10^{-17}\right]$ kényszert vezették le. A fenti értékek összhangban vannak az eredményeinkkel.

Erôsebb kényszer származik $\left(\omega_{0}^{(S a g)}=8 \times 10^{-10}\right)$ az S2 csillag keringéséből a szupermasszív fekete lyuk körül [92]. (Azonban még ez sem képes kizárni - hasonlóan az 5.2.2 szakasz eredményéhez - azt, hogy a Galaxis magjában csupasz szingularitás legyen, hiszen $\omega_{0}^{(\operatorname{Sag})}<0.5$.) 


\section{6. fejezet}

\section{Gyenge gravitációs lencsézés $\mathbf{R}^{n}$ gravitációelméletben}

A gravitációs mező Lagrange függvényének módosítása hatással van a gravitációs lencsézésre. A [99] cikk általános $f\left(R, R_{\mu \nu}^{\mu \nu}, R_{\mu \nu \alpha \beta} R^{\mu \nu \alpha \beta}\right)$ alakú Lagrange függvénnyel tárgyalt lencsézést. A módosított elméletek ÁRE határesettel rendelkeznek. A [100] cikk azt állapította meg, hogy ha a tömegpont potenciálját Yukawa típusú korrekcióval módosítjuk, akkor a gyenge lencsézés révén nem különböztethetố meg a két elmélet.

Ebben a fejezetben a hatványfüggvény alakú $f(R) \propto R^{n}$ ( $n$ pozitív egész) gravitációelmélet keretén belül tanulmányozzuk a lencsézést [4]. Gyenge lencsézést vizsgálunk olyan kompakt égitest jelenlétében, amelynek a téridőjét az $R^{n}$ elméletben vezettük le (3.3.1 szakasz). Ezt az objektumot már alkalmazták a galaktikus rotációs görbék elemzésére [67], [101]. A metrikát a $\sigma$ gravitáció erősség paraméter és az $r_{c}$ távolság skála jellemzi. Utóbbi a gyenge lencse feltevés miatt nagyságrendekkel nagyobb a gravitációs sugárnál. Az $r_{c}$ sugáron kívül a gravitáció erôsebb, mint ami a newtoni potenciálból következne (6.1 ábra). Ezért a lencsézés megfigyelhető következményei eltérnek a Schwarzschild esettől.

\subsection{Az elhajlási szög}

A [94] cikkben gyenge lencsézést vizsgáltak, amelyben a lencse olyan pontszerú objektum volt, amelynek potenciálja (3.16). Az elhajlási szögre az alábbi eredményt vezették le:

$$
\delta=\frac{2 G m}{c^{2} b}\left[1+\frac{\sqrt{\pi}(1-\sigma) \Gamma(1-\sigma / 2)}{2 \Gamma(3 / 2-\sigma / 2)}\left(\frac{b}{r_{c}}\right)^{\sigma}\right] .
$$

A (3.16) potenciál nem csak a $\sigma=0(\mathrm{n}=1)$ esetben egyszerúsödik a newtoni értékre, hanem akkor is ha $r=r_{c}$. Az $r<r_{c}$ tartományban a gravitáció gyengébb, az $r_{c}<r$ tartományban erősebb. Az 6.1 ábrán a $\Phi\left(r ; \sigma, r_{c}\right) / \Phi_{N}(r)$ arányt ábrázoltuk $\sigma$ és $r$ függvényében, a $0 \leq$ $\sigma<1, r \geq r_{c}$ tartományban. Az $r_{c}$ értékét úgy rögzítettük, hogy egy tipikus spirálgalaxis bulge sugarával azonosítottuk: $r_{c} \approx r_{\text {bulge }}=3240 \mathrm{pc}$, ami megfelel a $10^{20}$ m nagyságrendnek [68]. Az $m$ tömegnek a tipikus bulge tömeget adtuk értékként $\left(m_{\text {bulge }}=10^{10} M_{\odot}\right)$. Ezekkel a választásokkal a gravitáció erôsödik az $r_{\text {bulge }}$ sugáron kívül a newtoni esethez képest. Ez egy alternatív magyarázat a lapos galaktikus rotációs görbékre, a sötét anyag helyett [69].

Ha $\sigma=0$, akkor a Schwarzschild elhajlást kapjuk: $\delta_{S}=4 \mathrm{Gm} / \mathrm{c}^{2} b$, a $\sigma \rightarrow 1$ határátmenetben pedig $\delta_{\sigma \rightarrow 1}=\delta_{S} / 2$. A két szélső eset között a $\delta$ szög viselkedését a 6.2 ábra mutatja. Ha tetszőleges rögzített $\sigma$ mellett növeljük az impakt paramétert, akkor az elhajlási szög csökken, hasonlóan a Schwarzschild lencsézéshez. Ha az impakt paraméter összemérhető $r_{c}$-vel, akkor $\delta(b)$ kevésbe csökken, mint a Schwarzschild lencsézésnél. A $b / r_{c}$ aránynak van egy kritikus értéke $\left(b / r_{c}\right)_{\text {crit }}=2$, amely alatt $\delta$ szigorúan csökken $\sigma$ növekedésével, és amely felett egy $\sigma_{\delta_{\max }}$ 


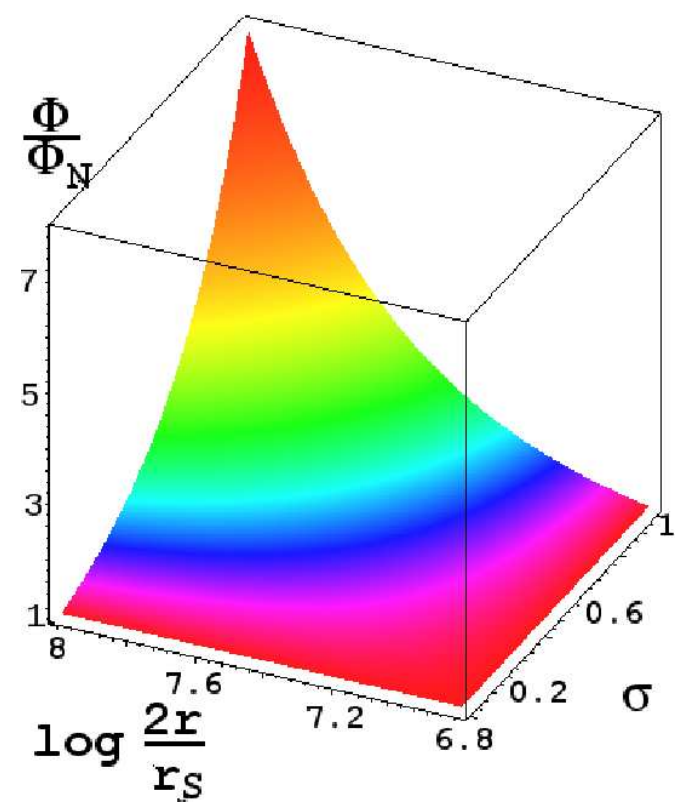

6.1. ábra. Az $f(R) \propto R^{n}$ potenciál és a newtoni potenciál aránya a $\sigma \in[0,1)$ paraméter és az $r \geq r_{c}$ távolság függvényében. A tipikus galaxis bulge tömeget és sugarat választottuk az ábra elkészítéséhez: $m_{\text {bulge }} \approx 10^{10} M_{\odot}$ és $r_{c} \approx r_{\text {bulge }} \approx 3240$ pc. A lencse Schwarzschild sugara $r_{S}=2 m$.

értéknél létezik egy globális maximum. Minden $r_{c}$ értékhez tartozik egy kritikus impakt paraméter, amelyre az elhajlás szögének viselkedése megváltozik. A $\sigma_{\delta_{\max }}$ maximumhely növekvő függvénye $b / r_{c}$-nek. 


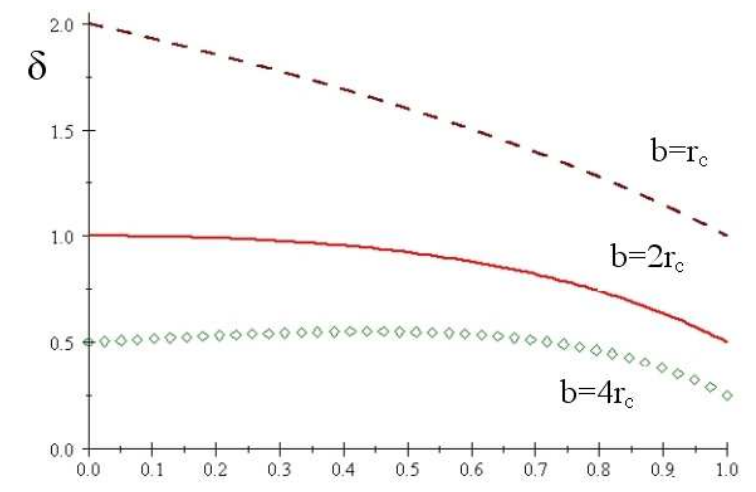

a)

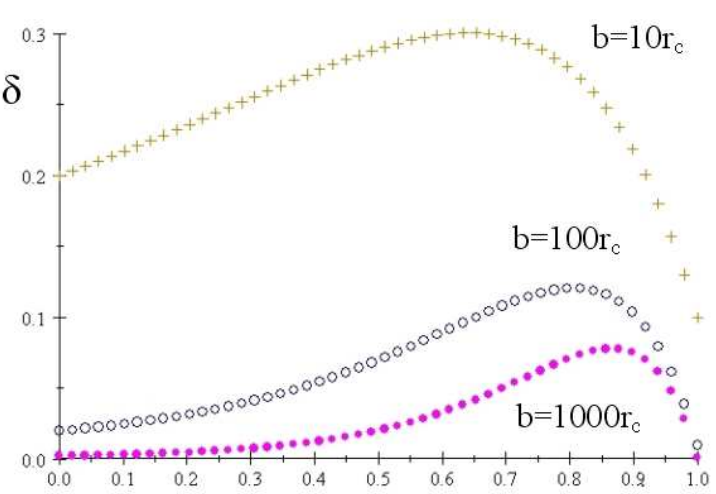

b)

$\sigma$

6.2. ábra. A $\delta(\sigma)$ függés radiánban, a $b / r_{c}$ arány különböző értékeire, a $2 G m / c^{2} r_{c}=1$ egységben, az $r_{c}=3240 \mathrm{pc}$ választással. A feltüntetett $b / r_{c}$ értékek 1 (vonalkázott), 2 (folytonos), 4 (gyémánt), 10 (kereszt), 100 (kör), 1000 (pontozott). A kritikus viselkedés $b / r_{c}=2$-nél jelenik meg.

\subsection{Lencseegyenletek}

A lencsézés geometriája a 6.3 ábrán látható. $S$ a forrás és $I_{1,2}$ a képek helyzete. Az $S$ és $I_{1,2}$ pontok vetülete az $O N$ optikai tengelyre $N$, ezzel a lencse és forrás $D_{l s}=|\overline{L N}|$ (vetített) távolságát, ill. a megfigyelő és a forrás $D_{s}=|\overline{O N}|$ (vetített) távolságát definiáljuk. A megfigyelő és a lencse távolsága $D_{l}=D_{s}-D_{l s}$. A forrás helyzetét a $\beta=\widehat{L O S}>0$ valódi szöggel jellemezzük. A $\theta=\widehat{I O L}$ látszólagos szöget előjeles mennyiségnek tekintjük (a pozitív látszó szögek az optikai tengely feletti, a negatív látszó szögek az optikai tengely alatti képekhez tartoznak). Bevezetjük az $s=\operatorname{sgn} \theta$ előjelet, amivel a lencseegyenlet megoldásait különböztetjük meg. Az $s$ előjellel a kisszögú lencseegyenlet

$$
|\theta|-s \beta-\frac{D_{l s}}{D_{s}} \delta=0
$$

alakú. A [94] cikkben a kisszögű egyenletet alkalmazták a gyenge lencsézés tárgyalására.

Pontosabb eredményeket ad a Virbhadra-Ellis lencseegyenlet [11]:

$$
\tan |\theta|-\tan (s \beta)-\frac{D_{l s}}{D_{s}}[\tan |\theta|+\tan (\delta-|\theta|)]=0,
$$

ill. a Dabrowski-Schunck egyenlet [12]:

$$
\sin \alpha=\frac{D_{l s}}{D_{s}} \cos |\theta| \cos \left[\arcsin \left(\frac{D_{s}}{D_{l s}} \sin (|\theta|-\alpha)\right)\right][\tan |\theta|+\tan (\delta-|\theta|)] .
$$

( $\alpha:=\theta-\beta$ a redukált elhajlási szög) A 4. fejezetben a (4.5) lencseegyenletet vezettük le. Azt is beláttuk, hogy következik belőle a Virbhadra-Ellis egyenlet mint egy jól definiált közelítés. A két egyenlet a (4.9) kis paraméterek elsô rendjében megegyezik. Ebben a fejezetben nem törekszünk másodrendú effektusok figyelembevételére. Tehát megelégedünk a Virbhadra-Ellis egyenlet alkalmazásával. Az impakt paraméter $b=D_{l} \sin |\theta|$ (5.1 ábra), így a (6.1) képlet összefüggés $\delta$ és $\theta$ között. Egy másik összefüggés a két szög között valamelyik lencseegyenlet. Bármelyik lencseegyenlet a (6.1) képlettel együtt zárt egyenletrendszert alkot a $\theta, \delta$ változókra. Az egyenletrendszer a $\sigma$ és $\bar{\varepsilon}$ paraméterek rögzítése után numerikusan megoldható. 


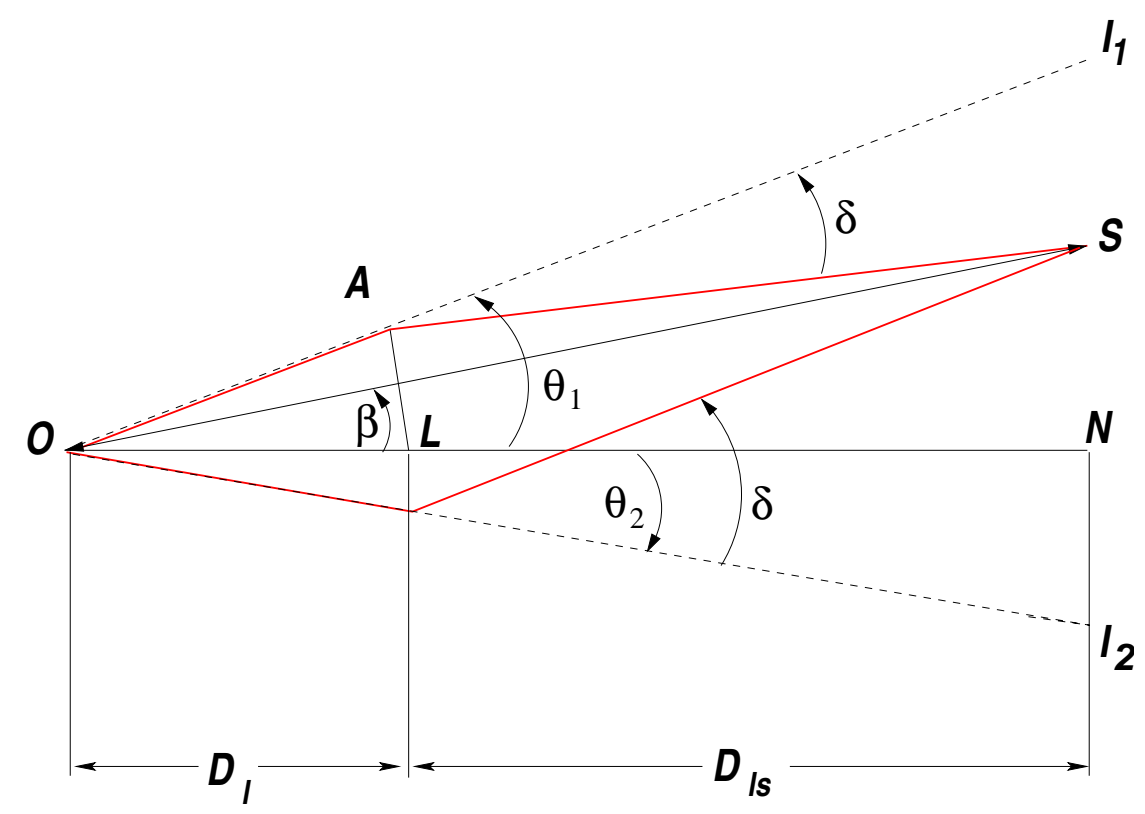

6.3. ábra. A lencsézés geometriája: $S$ a forrás és $I_{1,2}$ a képek helyzete. Az $S$ és $I_{1,2}$ pontok vetülete az $O N$ optikai tengelyre $N$. A lencse és a forrás sík távolsága $D_{l s}$, a megfigyeló és a forrás sík távolsága $D_{s}=|\overline{O N}|$. A megfigyelő és a lencse távolsága $D_{l}$. A forrás helyzetét a $\beta>0$ szöggel jellemezzük (a pozitív szögeket az óramutató járásával ellentétes ívekkel ábrázoljuk). A $\theta=\widehat{I O L}$ látszó szög előjeles $(s=\operatorname{sgn} \theta)$ mennyiség. A pozitív látszó szögek az optikai tengely feletti, a negatív látszó szögek az optikai tengely alatti képekhez tartoznak.

A 6.4 ábra demonstrálja, hogy a képek és nagyítások számolására a (6.3) egyenlet elegendően pontos, a megfigyelésekkel való összevetés szempontjából. A bal panelen a (6.3) egyenletből kapott $\theta_{V E}$ Einstein szögek és a (6.2) egyenletből kapott $\theta_{0}$ Einstein szögek különbségét ábrázoltuk a $\sigma$ és $\bar{\varepsilon}$ paraméterek függvényében. Az eltérések mikroívmásodperc nagyságrendúek. A jobb panelen a (6.4) egyenletből kapott $\theta_{D S}$ pozitív látszó szög és a (6.3) egyenlet pozitív $\theta_{V E}$ megoldásának különbsége látható, $\beta=1$ " helyzetú forrás esetén. Annak ellenére, hogy a két különbség felület hasonló alakú, a jobb oldali felületen a szögek nagyságrendje nanoívmásodperc. 

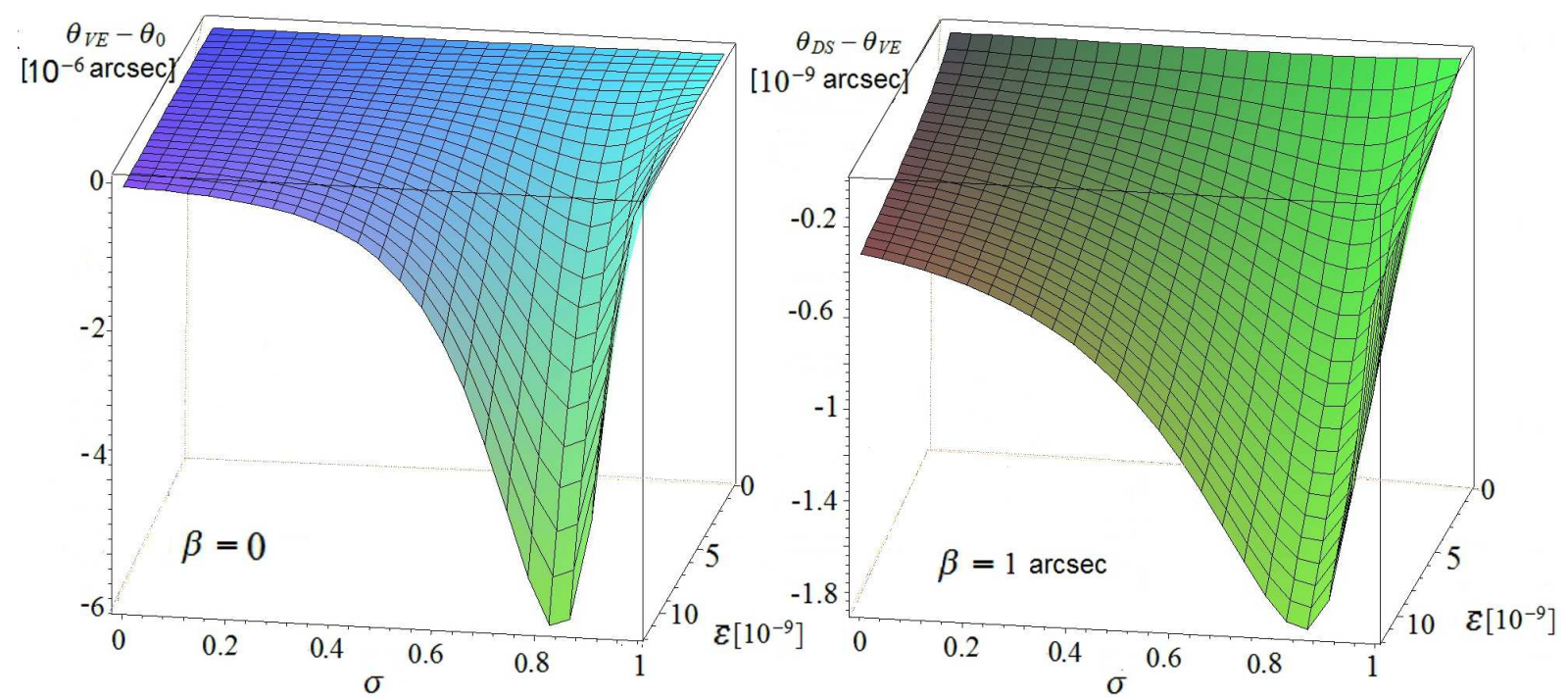

6.4. ábra. Bal panel: a $\theta_{V E}$ és $\theta_{0}$ Einstein szögek különbsége a $\sigma$ és $\bar{\varepsilon}$ paraméterek függvényében. Jobb panel: a $\beta=1$ " helyzetú forrás pozitív képeinek $\left(\theta_{D S}\right.$ ill. $\left.\theta_{V E}\right)$ különbsége. A két különbség felület hasonló alakú, de skálájuk 3 nagyságrenddel eltér.

6.1. táblázat. A $\kappa$ kitevők táblázata, amelyek a nagyítások arányára érvényes hatványtörvényben szerepelnek.

\begin{tabular}{|c||c|c|c|c|c|c|c|c|c|c|c|c|c|c|}
\hline$\sigma$ & 0 & 0.1 & 0.2 & 0.3 & 0.4 & 0.5 & 0.6 & 0.7 & 0.8 & 0.87 & 0.9 & 0.95 & 0.99 & 0.9999 \\
\hline$\kappa$ & 4.39 & 4.87 & 5.21 & 5.64 & 6.15 & 6.69 & 7.20 & 7.60 & 7.84 & 7.92 & 6.60 & 5.92 & 5.12 & 4.87 \\
\hline
\end{tabular}

\subsection{Képek helyzetei és nagyításai}

A (6.1), (6.3) egyenletrendszer numerikus megoldása megadja a képek helyzetét $\bar{\varepsilon}$ és $\beta$ függvényében. A $\sigma=0.25$ és 0.75 esetekben a látszó szögeket a 6.5 ábra mutatja be. Mindkét esetben csökkenő $\beta$-val a képek távolsága csökken. A $\beta=0$ metszet szimmetrikus a $\theta=0$ síkra. Ez azért van így, mert ez a metszet az Einstein gyúrúk sugarait tartalmazza. Kis $\beta$-ra a képek szögtávolságára $\left(\theta_{1}-\theta_{2}\right)_{\sigma=0.25}<\left(\theta_{1}-\theta_{2}\right)_{\sigma=0.75}$ áll fenn, míg nagy $\beta$-ra $\left(\theta_{1}-\theta_{2}\right)_{\sigma=0.25}>\left(\theta_{1}-\theta_{2}\right)_{\sigma=0.75}$.

Ez alapján elemzésünk a Virbhadra-Ellis egyenlet alkalmazásával pontosabb mint a [93] cikk 8. szakaszában található 1. posztnewtoni rendú számolás. A cikk szerint az $f(R)$ gravitációelmélet és az ÁRE megkülönböztethetetlenek, és a posztnewtoni paraméter $\gamma=1+(2.1 \pm$ 2.3) $\times 10^{-5}$ értékével konzisztensek.

A 6.6 ábrán a képek távolságát és nagyításait ábrázoltuk $\beta / \theta_{E}$ függvényeként, ha $\sigma=0.25$ ill. 0.75. A felső és az alsó folytonos görbék a $\mu_{1}$ ill. $\mu_{2}$ nagyításokat ábrázolják, arányuk a vonalkázott görbe. A pontozott görbe a képek távolsága az Einstein szöggel normálva. A legerősebb effektus a fluxusok arányában látszik. $\sigma$ növekedésével a fluxusok aránya egyre gyorsabban nő $\beta$-val. Ennek oka, hogy nagyobb $\sigma$-ra a pozitív kép nagyobb mértékben fényesedik.

\subsection{Hatványtörvény-szerú viselkedés}

A lencsézés megfigyelésében az alapvető mérések a szögtávolság két kép között, és a nagyítások aránya. Az elsố mérés nem igényel információt a lencse helyzetérôl. Nincs szükség az egyedi kép helyzetek ismeretére. A második méréshez nem kell az egyedi képek fényességeit 


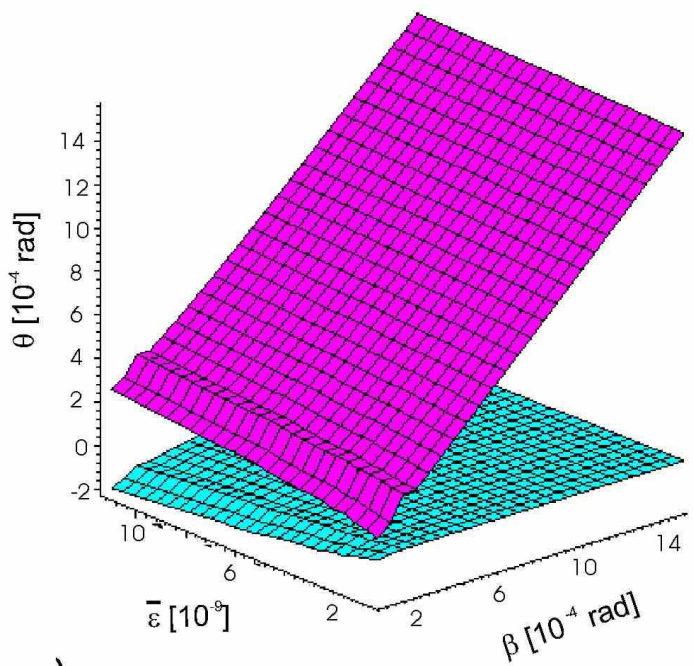

a)

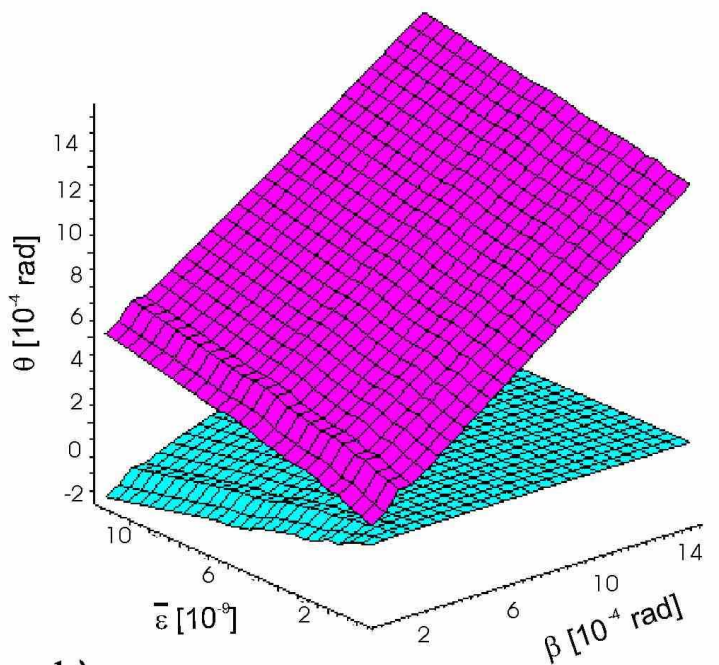

b)

6.5. ábra. A képek helyzete $\bar{\varepsilon}$ és $\beta$ függvényében a $\sigma=0.25$ (bal) és $\sigma=0.75$ (jobb) esetekben, a $D_{l}=1 \mathrm{Mpc}$ és $D_{l s}=2 \mathrm{Mpc}$ választással. A $\beta$ szöget 0.0015 radiánig változtattuk. Mindkét esetben csökkenő $\beta$-val a képek távolsága csökken. A $\beta=0$ metszet szimmetrikus a $\theta=0$ síkra, mert az Einstein szögeket tartalmazza.

megmérni.

A 6.7 ábra bal paneljén a $\mu_{1} / \mu_{2}$ arányt tüntettük fel a normált kép távolság függvényében (a normálást a $\sigma=0$ Schwarzschild esethez tartozó $\theta_{E}^{\sigma=0}$ Einstein sugárral végezzük), log-log skálán. Az ábrákhoz az $\bar{\varepsilon}=3.375 \times 10^{-9}, D_{l}=1 \mathrm{Mpc}, D_{l s}=2 \mathrm{Mpc}$ értékeket rögzítettük. A felső görbe a Schwarzschild lencsézést $(\sigma=0)$ jellemzi. A többi görbe a $\sigma$ értékek egy sorozatához tartozik, a legnagyobb érték 0.9999.

A 4.1.4 szakaszhoz hasonlóan, ha a képek távolsága meghaladja az Einstein szög kb. 2.5szörösét, akkor a fluxusok aránya a (4.39) hatványtörvénynek engedelmeskedik. A törvényben szereplő $\kappa$ kitevők (logaritmikus skálán a görbék meredekségei) a $\sigma$ függvényében a 6.7 ábra jobb paneljén és a 6.1 táblázatban találhatók. A $\kappa(\sigma)$ függvénynek kettôs degenerációja van elegendóen nagy $\sigma$-ra. A képek és fényességek mérésével ezen degeneráció erejéig lehetséges a különböző $\sigma$-hoz tartozó $R^{n}$ elméleteket megkülönböztetni. Jövőbeli lencsézési megfigyelések kényszereket rónak a $\sigma$ paraméterre.

Fontos észrevétel, hogy semmilyen $\sigma \neq 0$ értékhez sem tartozik ugyanaz a $\kappa$, mint a Schwarzschild lencsézéshez. A $\sigma=0$ érték kis környezetében nincs degeneráció. 


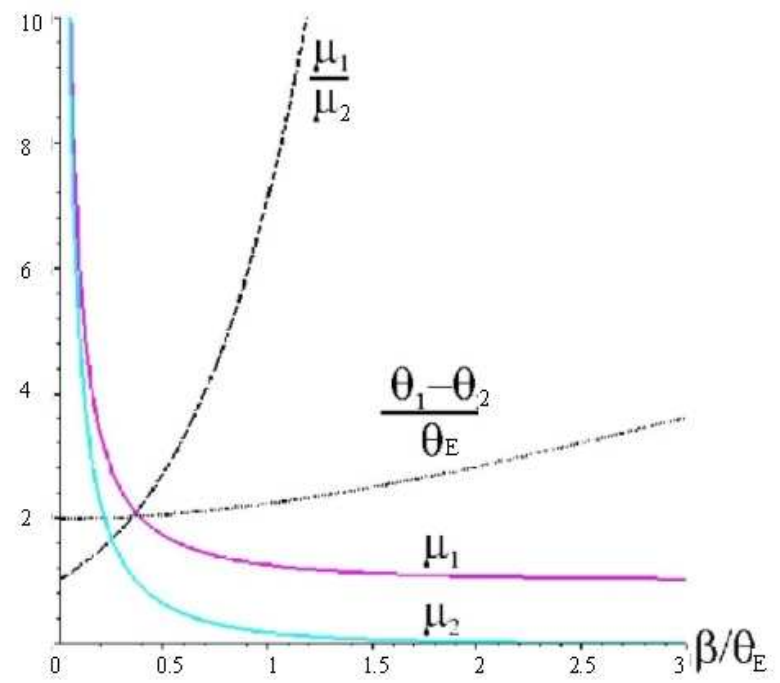

a)

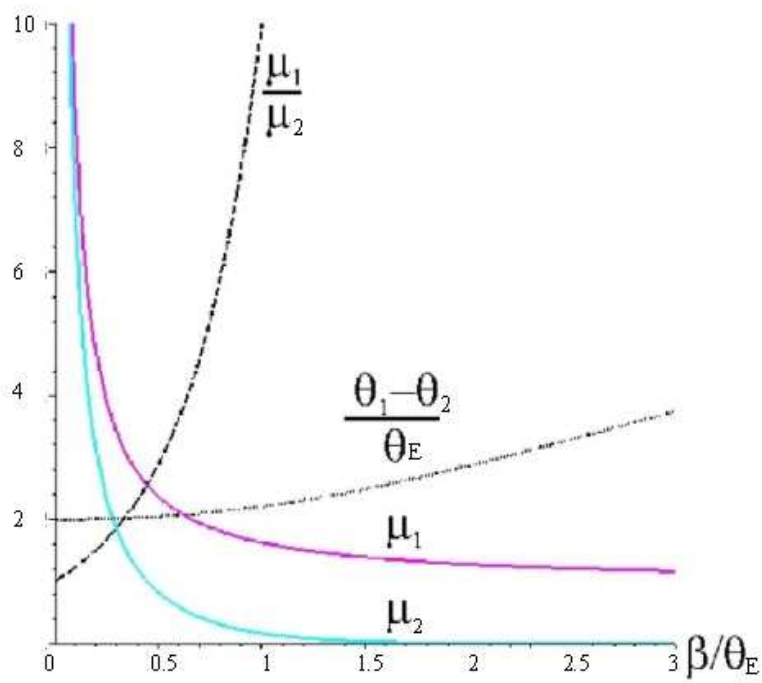

b)

6.6. ábra. A képek távolságai és nagyításai $\beta / \theta_{E}$ függvényeként, ha $\sigma=0.25$ (bal) és 0.75 (jobb). Az $\bar{\varepsilon}=3.375 \times 10^{-9}, D_{l}=1 \mathrm{Mpc}, D_{l s}=2 \mathrm{Mpc}$ paramétereket rögzítettük. A felső és az alsó folytonos görbék a $\mu_{1}$ ill. $\mu_{2}$ nagyításokat ábrázolják, arányuk a vonalkázott görbe. A pontozott görbe a normált kép távolság.

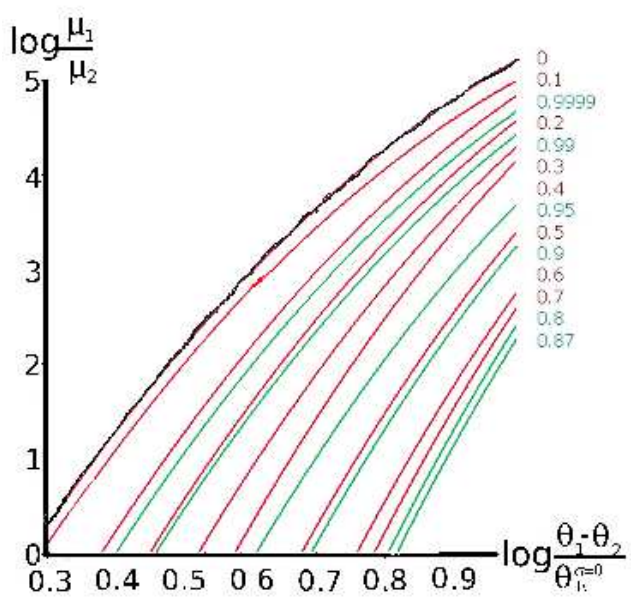

$\sigma$

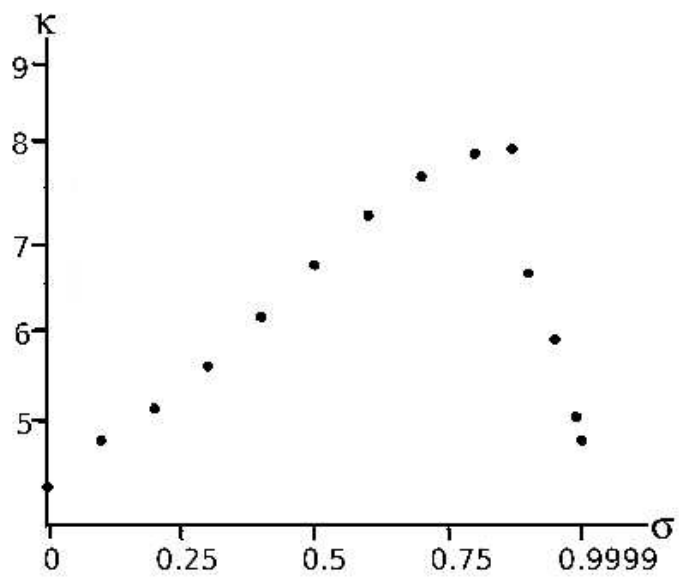

6.7. ábra. Bal panel: a képek nagyításainak aránya a normált kép távolság függvényében (a normálást a $\sigma=0$ Schwarzschild esethez tartozó $\theta_{E}^{\sigma=0}$ Einstein sugárral végezzük), log-log skálán a $\sigma$ értékek egy sorozatára. Jobb panel: a $\kappa(\sigma)$ függvénynek kettős degenerációja van, kivétel a maximumhely és $\sigma=0$ kis környezete. Az ábrákhoz az $\bar{\varepsilon}=3.375 \times 10^{-9}, D_{l}=1$ $\mathrm{Mpc}, D_{l s}=2 \mathrm{Mpc}$ értékeket rögzítettük. 


\section{7. fejezet}

\section{Összefoglalás}

A képek fényességének aránya a képek szögtávolságának függvényeként az árapálytöltésû fekete lyuk és az $f(R)$ elméletben levezetett kompakt égitest esetében olyan hatványtörvény, amely eltér a Schwarzschild fekete lyuk hatványtörvényétől. A fluxusok aránya a (4.39) hatványtörvénynek engedelmeskedik. Ez közös jellegzetessége az árapálytöltésú fekete lyuknak és az $f(R)$ elmélet lencséjének. Az árapálytöltésú esetet a 4.5 ábrán, az $f(R)$ esetet a 6.7 ábrán ábrázoltuk. Az árapálytöltésű fekete lyuk esetében a $\kappa$ kitevő kisebb, mint Schwarzschild lencsére. Az $f(R)$ elmélet lencséje esetében pedig $\kappa$ nagyobb, mint Schwarzschild esetben. Ezzel a megfigyeléssel tehát különbséget lehet tenni a két gravitációelmélet között.

Az alábbiakban az egyes elméletek tanulmányozása során kapott eredményeket foglaljuk össze.

\subsection{Az árapálytöltésú fekete lyuk gravitációs lencsézése}

Trigonometriai megfontolásokkal levezettük a (4.5) lencseegyenletet. Az egyenlet pontosabb a Virbhadra-Ellis egyenletnél. Ugyanakkor egy megfelelő határesetben a Virbhadra-Ellis egyenletre egyszerúsödik. A megoldásokat illetôen jelentős eltérés akkor várható, ha a forrás és a megfigyelő aszimmetrikusan helyezkedik el a lencséhez képest.

A (4.5) egyenlet alkalmazásával árapálytöltésú fekete lyukak lencsézését tanulmányoztuk. A tömeggel és az árapálytöltéssel arányos kis paraméterekben sorfejtéseket végeztünk. Ezután sorfejtéseket hajtottunk végre a forrás és a képek helyzetét jellemző kis szögekben. Ezáltal algebrai lencseegyenletekhez jutottunk.

A tárgyalt esetek közül a 4.1.5 szakaszban ismertetett árapálytöltés dominált lencsézés esetében a (4.5) és a Virbhadra-Ellis lencseegyenlet jóslatai különböznek. Ez abból következik, hogy a magasabb rendú tagok közül néhányat nem ad, vagy más együtthatóval ad a VirbhadraEllis egyenlet.

Elemeztuik, hogy hogyan módosul a képek távolsága, a nagyítások és a fluxusok aránya a Schwarzschild lencsézéshez képest, azoknak a perturbációknak a hatására, amik a fényelhajlási szög másodrendû tömeg- és első rendú árapálytöltés járulékából származnak. A legfeltûnőbb módosulás a fluxusok arányában jelenik meg, ezt a 4.2 ábra mutatja be. Az $\bar{\eta}-5 \bar{\varepsilon}^{2}$ mennyiség előjelétôl függốn a fluxusok aránya nagyobb vagy kisebb, mint a Schwarzschild esetben.

A tömeg dominált gyenge lencsézés esetében a képek helyzete hasonló, mint a ReissnerNordström fekete lyuk lencsézésekor, amelyet a [75] cikk tárgyal. Az árapálytöltés dominált lencsézés esetében a pozitív árapálytöltésû lencse hatása a negatív tömegú Schwarzschild lencse (csupasz szingularitás) lencsézési tulajdonságaira [96] hasonlít. A negatív árapálytöltés dominált esetben, a pozitív tömegú Schwarzschild lencse esetéhez hasonlóan, egy pozitív és egy negatív kép keletkezik. A képek tényleges helyzete azonban eltérô, ezt a 4.3 ábrák mutatják be. 
Az elsố relativisztikus Einstein gyứrú sugarának vizsgálata a Galaxis magjában található szupermasszív fekete lyuk árapálytöltésére a $q \in[-1.815,0.524] \times 10^{20} \mathrm{~m}^{2}$ kényszert adta.

\subsection{A Kehagias-Sfetsos fekete lyuk gravitációs lencsézése}

Képek keletkezését tanulmányoztuk gyenge és erős lencsézés során egyaránt, a Kehagias-Sfetsos téridőben, a Hořava-Lifshitz elmélet keretei között. A lencsét az $\bar{\varepsilon}$ tömeg paraméter mellett a $\bar{\lambda}$ Hořava-Lifshitz paraméter jellemzi. Ezek a paraméterek definíció szerint egy olyan skálázást tartalmaznak, amelyben a lencsézési geometriát jellemző $d$ hossz jelenik meg. A Schwarzschild limitet $\bar{\lambda} \rightarrow 0$, a sík határesetet $\bar{\lambda} \rightarrow \infty$ jellemzi. A közbensố tartomány jellegzetessége egy maximális $\delta_{\max }$ elhajlási szög ill. a hozzá tartozó $r_{\text {crit }}$ megközelítési távolság létezése. Ennek a jelenségnek nincs megfelelője a Schwarzschild lencsézésben. A gyenge lencsézés két képet okoz, ha $\bar{\lambda}$ kicsi. De minden tömeg és lencsézési geometria esetén valamilyen $\bar{\lambda}$-ra már csak a pozitív kép jön létre. Végül ahogy $\bar{\lambda} \rightarrow \infty$, ez a kép is egyre kevésbé tér el a forrás valódi helyzetétől, azaz $\theta / \beta \rightarrow 1$.

A $\theta$ látszó szög, az $r_{\min }$ minimális megközelítés és a $\delta$ elhajlás a következő egyenletrendszer megoldása: $\theta$-t és $\delta$-t a lencseegyenlet kapcsolja össze, egy integrál képlet megadja $\delta$-t $r_{\text {min }}$ függvényében, és egy algebrai kényszeregyenlet az $r_{\min }$ és a $b=D_{L} \sin (s \theta)$ ütközési paraméter között teremt összefüggést. A Virbhadra-Ellis lencseegyenlet alkalmaztuk. Az elhajlás szögét a pálya alak egyenletből származó integrállal számoltuk. A $\theta$ és $r_{\text {min }}$ mennyiségek közötti reláció a [46] cikkből származik.

Meghatároztuk a Hořava-Lifshitz paraméternek a megfigyelésekkel kompatibilis nagyságrendjét (5.1, 5.2 táblázatok), gyenge lencsézésből, 57 lencsegalaxis SDSS-ből származó fotometriai és spektroszkópiai adatai alapján. Tanulmányoztuk az elsô és a második relativisztikus Einstein gyưrüt is, amelyek erôs lencsézés során keletkeznek. Az irodalomból ismert egyéb kényszerekkel való összehasonlítás alapján az 5.2.2 szakaszban ismertetett, erôs lencsézésből származó kényszer a legerōsebb jelenleg.

\subsection{Gyenge gravitációs lencsézés $\mathbf{R}^{n}$ gravitációelméletben}

A gyenge lencsézés tulajdonságait elemeztük olyan kompakt égitest jelenlétében, amelynek téridôje az $R^{n}$ elméletben, a 3.3.1 szakaszban került levezetésre. A korábbi vizsgálatok ebben a téridőben [94] a kisszögú lencseegyenleten alapultak.

A gravitációs potenciált a (3.16) és (3.20) összefüggések jellemzik. Ebben megjelenik egy új paraméter $\sigma \in[0,1)$, amely a potenciál eltérését határozza meg a newtoni potenciáltól az $n$ kitevô függvényében. Az elmélet tartalmazza az ÁRE határesetet is ( $n=1$ ill. $\sigma=0)$. Az $n, \sigma$ paraméterek minden egyéb értékére az $r_{c}$ sugáron kívül a gravitáció erôsebb, mint ami a newtoni potenciálból következne. Következésképpen a lencsézés tulajdonságai eltérnek a Schwarzschild esettől.

Tárgyaltuk a (6.1) elhajlási szög függését a $\sigma$ és $b$ mennyiségektől. Ha tetszőleges rögzített $\sigma$ mellett növeljük az impakt paramétert, akkor az elhajlási szög csökken. A $b / r_{c}$ aránynak van egy kritikus értéke $\left(b / r_{c}\right)_{\text {crit }}=2$, amely alatt $\delta$ szigorúan csökken $\sigma$ növekedésével, és amely felett $\sigma_{\delta_{\max }}$ értéknél létezik egy globális maximum.

A képek helyzetét két $\sigma$ értékhez számoltuk ki. A nagyobbik $\sigma$-ra a képek távolsága gyorsabban nô a tömeg növelésével, és lassabban nő, ahogy a forrást távolítjuk az optikai tengelytôl. Rögzített $\beta$-ra $\sigma$ növekedésével a pozitív kép fényessége jelentôsen növekszik, a negatív képé kevésbé. A növekedés a legszembetúnőbb a $\mu_{1} / \mu_{2}$ fluxusok arányában.

A legkönnyebben mérhető mennyiségek - a szögtávolság két kép között és a nagyítások aránya - vizsgálata azt mutatja, hogy a fluxusok aránya a (4.39) hatványtörvénynek engedel- 
meskedik. A $\kappa$ kitevő függését $\sigma$-tól a 6.7 ábra jobb panelje és a 6.1 táblázat mutatja be. A $\kappa(\sigma)$ függvénynek kettős degenerációja van, kivéve a $\sigma=0$ ÁRE határeset kis környezetét.

A következő generációs rádió interferométerek pontossága elérheti a néhányszor tíz mikroívmásodperc pontosságot. A nagyítások arányát jellemző görbék $\kappa$ meredekségének mérésével a jövőbeli megfigyelések kényszereket adnak a $\sigma$ paraméterre, megerősítve az $f(R)$ elméletet ill. a (3.16) potenciállal rendelkezô égitest létezését. Vagy pedig, a $\sigma=0$ érték kimérésével cáfolhatják az $f(R)$ elméletet. 


\section{Summary}

The ratio of the fluxes of the images as a function of the separation of the images obeys a power law in the case of the tidal charged black hole and of the compact object derived in $f(R)$ theory as well, which differs from the power law of the Schwarzschild black hole. The ratio of the fluxes obeys the power law (4.39). This is a common feature of the tidal charged black hole and of the lens in the $f(R)$ theory. The tidal charged case is presented on Fig. 4.5, the $f(R)$ case is presented on Fig. 6.7. In the case of the tidal charged black hole the exponent $\kappa$ is smaller than the exponent for the Schwarzschild lens. In the case of the lens in the $f(R)$ theory the exponent $\kappa$ is larger than in the Schwarzschild case. This observation provides a distinction between the two theories of gravitation.

In what follows we summarize the results obtained from the study of the particular theories.

\section{Lensing by the tidal charged black hole}

We derived the lens equation (4.5) by trigonometric considerations. The equation is more accurate than the Virbhadra-Ellis equation. It reduces however to the Virbhadra-Ellis equation in a proper limit. As for the solutions significant differences are to be expected, if the source and the observer are placed asymmetrically with respect to the lens.

We applied the equation (4.5) in the discussion of the lensing by tidal charged black holes. We have carried on expansions in the small mass and tidal charge parameters. Then we have carried on expansions in the small angles related to positions of the source and the images. This way we obtained algebraic lens equations.

Among the various cases discussed the tidal charge dominated lensing presented in section 4.1.5 has different predictions from the lens equation (4.5) and the Virbhadra-Ellis equation. This follows from that the Virbhadra-Ellis equation does not predict some of the higher order terms, or it predicts them with different coefficients.

We have analysed how the image separations, the magnifications and the flux ratios are modified as compared to the Schwarzschild lensing, by the perturbations arising from second order mass and first order tidal charge contributions. The most apparent modification appears in the flux ratio, this is presented on Fig. 4.2. Depending on the sign of the quantity $\bar{\eta}-5 \bar{\varepsilon}^{2}$, the flux ratio can be either increased or decreased compared to the Schwarzschild lensing.

In the case of mass-dominated weak lensing the positions of the images are similar to the Reissner-Nordström black hole lensing, discussed by Ref. [75]. In the case of the tidal chargedominated lensing the effect of the lens with positive tidal charge resembles the lensing properties of a negative mass Schwarzschild lens (naked singularity) [96]. In the case of a dominant negative tidal charge, similarly to the positive mass Schwarzschild lens, one positive and one negative image emerge. The actual location of the images is different, this is shown on Figs. 4.3.

The study of the angular radius of the first relativistic Einstein ring led to the constraint $q \in[-1.815,0.524] \times 10^{20} \mathrm{~m}^{2}$ for the supermassive black hole in the Galactic Center. 


\section{Lensing by the Kehagias-Sfetsos black hole}

We studied image formation in weak and strong lensing as well in the Kehagias-Sfetsos spacetime in the framework of Hořava-Lifshitz theory. The lens is characterized by the mass parameter $\bar{\varepsilon}$ and the Hořava-Lifshitz parameter $\bar{\lambda}$. These parameters have such a scaling by definition which contains a characteristic length $d$ characterizing the lensing geometry. The Schwarzschild limit occurs when $\bar{\lambda} \rightarrow 0$. The space-time becomes flat in the limit $\bar{\lambda} \rightarrow \infty$. The intermediate range characterized by the existence of a maximal deflection angle $\delta_{\max }$, occurring at the distance of minimal approach $r_{\text {crit }}$. This feature does not exist in the Schwarzschild lensing. The weak lensing produces two images if $\bar{\lambda}$ is small. For every lens mass and geometry there is a $\bar{\lambda}$, such that only the positive image forms. Then as $\bar{\lambda} \rightarrow \infty$, there is only one almost undeflected image and $\theta / \beta \rightarrow 1$.

A closed system of equations for the image position $\theta$, the distance of minimal approach $r_{\min }$ and the deflection angle $\delta$ is given by: the lens equation relating $\theta$ and $\delta$, an integral formula to produce $\delta$ as a function of $r_{\min }$ and an algebraic constraint which connects $r_{\min }$ to the impact parameter $b=D_{L} \sin (s \theta)$. We have employed the Virbhadra-Ellis lens equation. The deflection angle was calculated by an integral obtained from the shape equation. The algebraic relation connecting $\theta$ and $r_{\min }$ was derived in [46].

We determined the order of the Hořava-Lifshitz parameter compatible with the observations, from weak lensing, based on photometric and spectroscopic data of 57 lens galaxies available from SDSS (tables 5.1, 5.2). We discussed also the first two relativistic Einstein rings emerging in strong lensing. We compared our constraints with related results in the literature and concluded that the constraints presented in section 5.2.2 are the strongest ones up to date.

\section{Weak gravitational lensing in $\mathbf{R}^{n}$ theory of gravitation}

We have analyzed the weak lensing signatures of the compact celestial object with the spacetime metric derived in section 3.3.1. The study of this space-time was based on the small angle lens equation in Ref. [94].

The gravitational potential is characterized by Eqs. (3.16) and (3.20). This introduces a new parameter $\sigma \in[0,1)$ which governs the deviation from the Newtonian potential for different values of the exponent $n$. General relativity corresponds to the special case $n=1$ and $\sigma=0$. For any other value of the parameters $n, \sigma$ the gravitation is stronger in the distances larger than the radius $r_{c}$ as compared to the prediction of the Newtonian potential. Therefore the lensing properties differ from the Schwarzschild lensing.

We discussed the dependencies upon $\sigma$ and $b$ of the deflection angle (6.1). The deflection angle decreases with increasing impact parameter for all fixed $\sigma$. The ratio $b / r_{c}$ has a critical value $\left(b / r_{c}\right)_{\text {crit }}=2$, below which $\delta$ monotonically decreases with increasing $\sigma$, and above which there is a global maximum.

We have computed the image positions for two specific values of $\sigma$. For the larger value of $\sigma$ the image separation grows faster with an increase in the mass and grows more slowly as the source moves away from the optical axis. For the same source position the magnification of the images increase with $\sigma$, especially the magnification of the positive image. The most apparent increase is found in the flux ratio $\mu_{1} / \mu_{2}$.

The analysis of the most easily measurable observables shows that the ratio of the magnifications has a power-law dependence (4.39) on the image separation. The dependence of the exponent $\kappa$ on the parameter $\sigma$ is presented on Fig. 6.7 and on table 6.1. The function $\kappa(\sigma)$ has a double degeneracy, except a small neighborhood of the GR limit $\sigma=0$.

The next generation of radio interferometers will be able to resolve images less then tens of microarcseconds accuracy. Measurements of the slope $\kappa$ of the curves characterizing the 
ratio of the magnifications should be able to constrain the parameter $\sigma$. The observations can either support or falsify the $f(R)$ theory and the existence of a compact object with the potential (3.16). 


\section{Köszönetnyilvánítás}

Szeretnék köszönetet mondani témavezetômnek, Dr. Gergely Árpád Lászlónak, aki irányította tevékenységemet a $\mathrm{PhD}$ éveim alatt. Az ô tudományos és személyes támogatása nélkül ez a munka nem jöhetett volna létre. A vezetése alatt eltöltött évek során mind szakmailag, mind emberileg sokat tanultam tôle.

Szeretném megköszönni a Szegedi Tudományegyetem Kísérleti Fizikai, valamint Elméleti Fizikai Tanszékeinek, hogy zavartalan kutatási feltételeket biztosítottak.

Szeretnék köszönetet mondani családomnak szeretetükért és támogatásukért.

Jelen kutatási eredmények megjelenését „Az SZTE Kutatóegyetemi Kiválósági Központ tudásbázisának kiszélesítése és hosszú távú szakmai fenntarthatóságának megalapozása a kiváló tudományos utánpótlás biztosításával" címú, TÁMOP-4.2.2/B-10/1-2010-0012 azonosítószámú projekt támogatja. A projekt az Európai Unió támogatásával, az Európai Szociális Alap társfinanszírozásával valósul meg. 


\section{Irodalomjegyzék}

[1] Z. Horváth, L. Á. Gergely, D. Hobill, Class. Quant. Grav. 27, 235006 (2010).

[2] Z. Horváth, L. Á. Gergely, Astron. Nachr. 344, 9, 1047 (2013).

[3] Z. Horváth, L. Á. Gergely, Z. Keresztes, T. Harko, F. S. N. Lobo, Phys. Rev. D 84, 083006 (2011).

[4] Z. Horváth, L. Á. Gergely, D. Hobill, S. Capozziello, M. De Laurentis, Phys. Rev. D 88, 063009 (2013).

[5] P. Schneider, J. Ehlers, E. E. Falco, Gravitational Lenses (Springer, 1992).

[6] E. B. Fomalont, R. A. Sramek, ApJ 199, 749 (1975).

[7] P. Schneider, Astron. Astrophys. 140, 119 (1984).

[8] V. Bozza, Phys. Rev. D 78, 103005 (2008).

[9] H.C. Ohanian, Am. J. Phys. 55, 428 (1987).

[10] V. Bozza, M. Sereno, Phys. Rev. D 73, 103004 (2006).

[11] K. S. Virbhadra, G. F. R. Ellis, Phys. Rev. D 62, 084003 (2000); K. S. Virbhadra, Phys. Rev. D 79, 083004 (2009).

[12] M. P. Dabrowski, F. E. Schunck, ApJ 535, 316 (2000).

[13] P. Young, ApJ 244, 756 (1981).

[14] M. Hazewinkel (szerk.), Encyclopaedia of Mathematics (Kluwer, 1994).

[15] J. H. Cooke, R. Kantowski, ApJ 195, L11 (1975).

[16] I. Shapiro, Phys. Rev. Lett. 13, 789 (1964).

[17] S. Refsdal, MNRAS 128, 295 (1964); R. Kayser, S. Refsdal, Astron. Astroph. 128, 156 (1983).

[18] P. Schneider, C. Seitz, Astron. Astroph. 294, 411 (1995).

[19] M. K. Mak, T. Harko, Phys. Rev. D 70, 024010 (2004).

[20] T. Harko, K. S. Cheng, Phys. Rev. D 76, 044013 (2007).

[21] P. Binétruy, C. Deffayet, U. Ellwanger, D. Langlois, Phys. Lett. B 477, 285 (2000).

[22] R. Maartens, Living Rev. Rel. 7, 1 (2004); R. Maartens, K. Koyama, Living Rev. Rel. 13, 5 (2010). 
[23] T. Shiromizu, K. Maeda, M. Sasaki, Phys. Rev. D 62, 024012 (2000).

[24] L. Á. Gergely, Phys. Rev. D 78, 084006 (2008).

[25] V. Sahni, Y. Shtanov, JCAP 0311, 014 (2003).

[26] L. Randall, R. Sundrum, Phys. Rev. Lett. 83, 4690 (1999).

[27] K. Maeda, S. Mizuno, T. Torii, Phys. Rev. D 68, 024033 (2003).

[28] L. Á. Gergely, R. Maartens, Phys. Rev. D 71, 024032 (2005).

[29] M. Bruni, C. Germani, R. Maartens, Phys. Rev. Lett. 87, 231302 (2001).

[30] S. Pal, Phys. Rev. D 74, 124019 (2006).

[31] L. Á. Gergely, JCAP 0702, 027 (2007).

[32] C. Lánczos, Phys. Zeit. 23, 537 (1922); W. Israel, Nouvou Cimento B XLIV, 4349 (1966).

[33] L. Á. Gergely, Phys. Rev. D 68, 124011 (2003).

[34] N. Kaloper, D. Kiley, JHEP 0603, 077 (2006).

[35] P. Kanti, K. Tamvakis, Phys. Rev. D 65, 084010 (2002).

[36] P. Kanti, I. Olasagasti, K. Tamvakis, Phys. Rev. D 68, 124001 (2003).

[37] R. Emparan, A. Fabbri, N. Kaloper, JHEP 0208, 043 (2002).

[38] H. Kudoh, T. Tanaka, T. Nakamura, Phys. Rev. D 68, 024035 (2003).

[39] A. Chamblin, S. W. Hawking, H. S. Reall, Phys. Rev. D 61, 065007 (2000).

[40] S. Seahra, C. Clarkson, R. Maartens, Phys. Rev. Lett 94, 121302 (2005).

[41] J. Garriga, T. Tanaka, Phys. Rev. Lett. 84, 2778 (2000).

[42] S. B. Giddings, E. Katz, L. Randall, JHEP 03, 023 (2000).

[43] L. Á. Gergely, Phys. Rev. D 74, 024002 (2006).

[44] N. Dadhich, R. Maartens, P. Papadopoulos, V. Rezania, Phys. Lett. B 487, 1 (2000).

[45] L. Á. Gergely, N. Pidokrajt, S. Winitzki, Eur. Phys. J. C71, 1569 (2011).

[46] L. Á. Gergely, Z. Keresztes, M. Dwornik, Class. Quant. Grav. 26, 145002 (2009).

[47] A. Kotrlova, Z. Stuchlik, F. Török, Class. Quant. Grav. 25, 225016 (2008).

[48] G. C. Böhmer, T. Harko, F. S. N. Lobo, Class. Quant. Grav. 25, 045015 (2008).

[49] P. Hořava, JHEP 0903, 020 (2009).

[50] P. Hořava, Phys. Rev. D 79, 084008 (2009).

[51] M. Visser, arXiv:1103.5587 [hep-th] (2011).

[52] A. Kehagias, K. Sfetsos, Phys. Lett. B 678, 123 (2009). 
[53] A. G. Riess et al., AJ 116, 1009 (1998); S. Perlmutter et al., ApJ 517, 565 (1999); R. A. Knop et al., ApJ 598, 102 (2003); J. L. Tonry et al., ApJ 594, 1 (2003); B. J. Barris et al., ApJ 602, 571 (2004) al., ApJ 545, 1 (2000); S. Hanany et al., ApJ 545, 5 (2000); T. J. Pearson et al., ApJ 591, 556 (2003).

[54] P. de Bernardis et al., Nature 404, 955 (2000); A. Balbi et al., ApJ 545, 1 (2000); S. Hanany et al., ApJ 545, 5 (2000); T. J. Pearson et al., ApJ 591, 556 (2003).

[55] C. L. Bennett et al., ApJS 148, 1 (2003); D. N. Spergel et al., ApJS 148, 175 (2003).

[56] S. Carloni, P. K. S. Dunsby, S. Capozziello, A. Troisi, Class. Quant. Grav. 22, 4839 (2005); S. Capozziello, V.F. Cardone, A. Trosi, Phys. Rev. D, 71, 043503 (2005).

[57] S. Capozziello, Int. J. Mod. Phys. D 11, 483 (2002).

[58] S. Nojiri, S. D. Odintsov, Int. J. Geom. Meth. Mod. Phys. 4, 115 (2007); S. Capozziello, M. Francaviglia, Gen. Rel. Grav. 40, 357 (2008); S. Capozziello, M. De Laurentis, V. Faraoni, Open Astron. J. 3, 49 (2010); T. P. Sotiriou, V. Faraoni, Rev. Mod. Phys. 82, 451 (2010).

[59] S. Nojiri, S. D. Odintsov, Phys. Lett. B 576, 5 (2003); S. Nojiri, S. D. Odintsov, Mod. Phys. Lett. A 19, 627 (2003); S. Nojiri, S. D. Odintsov, Phys. Rev. D 68, 12352 (2003); S. M. Carroll, V. Duvvuri, M. Trodden, M. Turner, Phys. Rev. D 70, 043528 (2004).

[60] M. Amarzguioui, O. Elgaroy, D. F. Mota, T. Multamaki, Astron. Astrophys. 454, 707 (2006) ; P. Zhang, Phys. Rev. D 73, 123504 (2006).

[61] D. N. Vollick, Phys. Rev. D 68, 063510 (2003); X. H. Meng, P. Wang, Class. Quant. Grav. 20, 4949 (2003); E.E. Flanagan, Class. Quant. Grav. 21, 417 (2004); X. H. Meng, P. Wang, Class. Quant. Grav. 21, 951 (2004); G.M. Kremer, D. S. M. Alves, Phys. Rev. D 70, 023503 (2004).

[62] G. Allemandi, A. Borowiec, M. Francaviglia, Phys. Rev. D 70, 043524 (2004); G. Allemandi, A. Borowiec, M. Francaviglia, Phys. Rev. D 70, 103503 (2004).

[63] S. Nojiri, S. D. Odintsov, Gen. Rel. Grav. 36, 1765 (2004); X. H. Meng, P. Wang, Phys. Lett. B 584, 1 (2004).

[64] S. Capozziello, V. F. Cardone, S. Carloni, A. Troisi, Int. J. Mod. Phys. D 12, 1969 (2003).

[65] S. Capozziello, V. F. Cardone, M. Francaviglia, Gen. Rel. Grav. 38, 711 (2006).

[66] S. Capozziello, V. Faraoni, Beyond Einstein Gravity: A Survey of Gravitational Theories for Cosmology and Astrophysics (Springer, 2010); S. Capozziello, M. De Laurentis, Invariance Principles and Extended Gravity: Theory and Probes (Nova Science Publishers, 2010).

[67] S. Capozziello, V. F. Cardone, A. Troisi, MNRAS 375, 1423 (2007).

[68] L. Á. Gergely, T. Harko, M. Dwornik, G. Kupi, Z. Keresztes, MNRAS 415, 3275 (2011).

[69] C. F. Martins, P. Salucci, MNRAS 381, 1103 (2007).

[70] S. Pal, S. Bharadwaj, S. Kar, M. Sinha, Gen. Rel. Grav. 35, 10 (2003).

[71] A. S. Majumdar, N. Mukherjee, Mod. Phys. Lett. A20, 2487 (2005). 
[72] R. Whisker, Phys. Rev. D 71, 064004 (2005).

[73] A. S. Majumdar, N. Mukherjee, Int. J. Mod. Phys. D 14, 1095 (2005).

[74] L. Á. Gergely, B. Darázs, Publ. Astron. Dep. Eötvös Univ. 17, 213 (2006).

[75] M. Sereno, Phys. Rev. D 69, 023002 (2004).

[76] A. Eckart, R. Genzel, MNRAS 284, 576 (1997).

[77] S. Gillessen et al., ApJ 692, 1075 (2009).

[78] C. M. Will, ApJL 674, L25 (2008).

[79] D. Merritt, T. Alexander, S. Mikkola, C. M. Will, Phys. Rev. D 81, 062002 (2010).

[80] S. Gillessen et al., Proceedings of SPIE Astronomical Telescopes and Instrumentation Conference (2010).

[81] A. Y. Bin-Nun, Phys. Rev. D 82, 064009 (2010).

[82] A. Y. Bin-Nun, Phys. Rev. D 81, 123011 (2010).

[83] A. Y. Bin-Nun, Class. Quant. Grav. 28, 114003 (2011).

[84] S. Weinberg, Gravitation and Cosmology (Wiley, 1972).

[85] LSST Science Collaborations, LSST Science Book Version 2.0, www.lsst.org/lsst/scibook (2009).

[86] A. S. Bolton, S. Burles, L. V. E. Koopmans, T. Treu, L. A. Moustakas, ApJ 638703 (2006).

[87] C. Grillo, R. Gobat, M. Lombardi, P. Rosati, Astron. Astroph. 501, 461 (2009).

[88] S. Gonzaga et al., ACS Data Handbook Version 6.0, www.stsci.edu/hst/acs/documents/handbooks/currentDHB (2011).

[89] T. Harko, Z. Kovács, F. S. N. Lobo, Proc. Roy. Soc. Lond. A Math. Phys. Eng. Sci. 467, 1390 (2011); F. S. N. Lobo, T. Harko, Z. Kovács, Class. Quant. Grav. 28, 165001 (2011).

[90] L. Iorio, M. L. Ruggiero, Int. J. Mod. Phys. D20, 1079 (2011).

[91] M. Liu, J. Lu, B. Yu, J. Lu, Gen. Rel. Grav. 43, 1401 (2010).

[92] L. Iorio, M. L. Ruggiero, Open Astron. J. 3, 167 (2010).

[93] C. P. L. Berry, J. R. Gair, Phys. Rev. D 83, 104022 (2011).

[94] S. Capozziello, V. F. Cardone, A. Troisi, Phys. Rev. D 73, 104019 (2006).

[95] T. P. Sotiriou, V. Faraoni, Phys. Rev. Lett. 108, 081103 (2012).

[96] J. G. Cramer, R. L. Forward, M. S. Morris, M. Visser, G. Benford, G. A. Landis, Phys. Rev. D 51, 3117 (1995).

[97] C. Germani, R. Maartens, Phys. Rev. D 64, 124010 (2001).

[98] S. Kinoshita, H. Kudoh, Y. Sendouda, K. Sato, Class. Quant. Grav. 22, 3911 (2005). 
[99] A. Stabile, A. Stabile, Phys. Rev. D 85, 044014 (2012).

[100] M. Lubini, C. Tortora, J. Näf, P. Jetzer, S. Capozziello, Eur. Phys. J. C 71, 1834 (2011).

[101] A. Stabile, G. Scelza, Phys. Rev. D 84, 124023 (2011).

[102] L. Witten (szerk.), Gravitation: an introduction to current research (Wiley, 1962). 